\title{
GEOLOGY AND GEOCHEMISTRY OF THE CRAIG A-2 QUADRANGLE AND VICINITY, PRINCE OF WALES ISLAND, SOUTHEASTERN ALASKA
}

By

Gordon Herreid, Thomas K. Bundtzen, and Donald L. Turner

GEOLOGIC REPORT 48

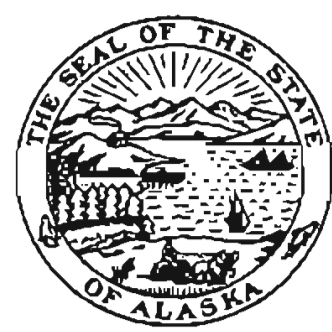


STATE OF ALASKA

Jay S. Hammond, Governor

Robert E. LeResche, Commissioner; Dept. of Natural Resources

Ross G. Schaff, State Geologist

STAFF

C.M. Adams, Cartogragher

M.R. Ashwell, Iaboratory assistant

N.J. Bragk, Secretary

G.A. Broker, Clerk-typist

M.E. Brown Geologic Information techrician

T.K. Bundtzen, Mining geologist

C.N. Conwel, Mining engincer

P. Coonrod, Clerk-typlst

N.D. Coursey, Geochemical andy st

C.L. Daniels, Geological assistani,

J.T. DUJon, Mining geologist

G.R. Eaklns. Chlef mining seologist

K.S. Emmel, Geologlod asslstant

W.G. Gilbert, Mlaing geologist

S.W. Hackell. Exploration geophysicist

M.W. Hennisg, Miaing geologist

J.T. Kline, Geologieal assistant

c.C. Landis, Clerk
L. F. Larson, Publicatlons specialist

W.E. Loug, Hydrologiat

W.M. Lylo, Petroleum geologist

R.A. Mann. Clerk

U.O. MCBride, Clerk

D.L. McGee, Petroleum geologist

J. Newgaard, Accountane

G.H. Pessel, Petroleum geologist

R.D. Reger, Geologist

J.R. Riehle. Geologleal engineer

R.G. Schaff, State Geologisi

L.C. Sehell, Cartographer

R.H. Schultz, Laboratary techniclan

D.R. Stein, Assayex

C.H. Stevenson, Geologic information techbictan

N.C. Veaoh, A ssayer chemist

G.M. Zartmen, Clexts

For sale by Alaska Dlvision of Geolosical and Geophysical Surveys, P.D. Box 80007, College, 99708; J327 Fairbanks S1, Anchorake, 99503: P.O. Box 7438. Ketchikan, 99901: and Pouch M. Juneau, 89811. 


\section{CONTENTS}

Summary.

Scope of present investigations.

Previous investigations..

Geography.

Geologic units.

Wales Group.

Introduction.

Marble (Wm)

Dolomite-rich marble (Wdm)

Dark-gray phyllite (Wp).

Pbyllite, marble, and green schist (Wpmg)......

Green tuffaceous sehist $\left(\mathrm{W}_{\mathrm{g}}\right)$

Metakeratophyre tuff(?) and related rocks (K, Kxt, Kd) .

Quartz sericite schist (Ws).

Silicified schist (Wss)

Phyllite and limestone (Wpl)

Migmatitic gneiss (Wgm).

Age of the Wales Group.

Descon Formation

Introduction.

Spilite(?) and mixed volcanic rocks (Odv).

Sheared conglomeratic gray wacke (Odsg)

Banded mudstone (Odm)...

Gray wacke (Odg)

Argillite (Oda).

Basalt (Odb)

Age of the Descon Formation

Silurian(?) igneous rocks.

Altered granodiorite (Sgd)

Alaskite (Sa).

Keratophyre(?) (Sk)

Dovonian beddod rock units

Introduction

Basal conglomerate and red beds (Dbc, Dar).

Argillite-siltstone (Da), siltstone-gray wacke (Dsg), pebble-conglomerate (Dpc), limestone (DI), and felsite pebble conglonerate (Dkpc) Age.

Andesite(?) (Dand)..

Paleozoic(?) dikes (Pdk)

Introduction.

Felsite dikes.

Amygdaloidal porphyritic basaltic andesite dikes.

Porphyritic diabase dikes.

Amygdaloidal porphyritic andesite dikes.

Thermally metamorphosed dikes.

Structure

Age.

Cretaceous intrusive rocks

Altered porphyritic diorite (Kdip)

Granodiorite (Kgdi)...

Epidotized gabbro and diorite (Keg)

Breccia dikes (Kbd)

Age.

Thermally metamorphosed rocks.

Hornfels ( Kh)

Actinolitic hornfels (Kah).

Age. 


\section{CONTENTS (cont.)}

Structure.

Small-scale features associated with penetrative deformation

Foliation.

Crenulations

Minor folds

Boudinage.

Kink bands..

Large-scale faults and foids

Thrust faults.

Age of thrusting.

High-angle faults

Folds..

Whole-rock major oxide analyses of igneous rocks

Elemental geochemistry.

Analytical techniques.

Anomalous areas.

Mineral deposits.

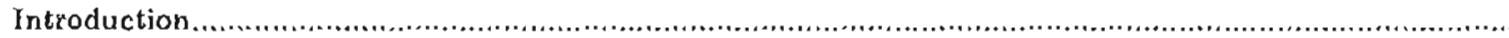

Dolomite deposits (D).

Quartz boudins and silicified zones

Jumbo Mine.

Magnetite Cliff deposit.

Upper magnetite bodies.

Gonnason deposit

Copper Mounlain deposits.

Houghton prospect.

Small skarn prospects near the Houghton prospect.

Green Monster Mountain prospects

Gould Island prospect.

Hetta Mountain prospects..

Corbin Mine.

Copper City Mine...

Lime Point baxite prospect

Nutkwa Lagoon prospect.

Keete Inlet prospect.

Friendship silicified zone

Discussion

Moonshine Group

Acknowledgments.

References cited.

\section{TABLES}

TABLE 1. Modes of selected granodiorite and related rocks ( $\mathrm{Kgdi}$ ).

2. Bulk chemical analyses of 12 plutonic, volcanic, and metavolcanic rocks from the Craig A-2 quadrangle and vicinity, and 13 examples from literature.

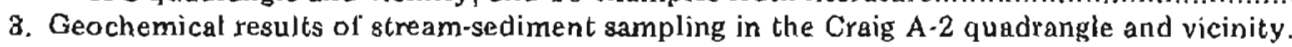

4. Geochemical results of rock samples from the Craig A-2 quadrangle and vicinity.

5. Summary listing of known mineral occurrences in the Craig A.2 quadrangle and vicinity..................

In pocket

In pocket

\section{ILLUSTRATIONS}

PLATE 1. Geologic map of the Craig A-2 quadrangle and vicinity, Prince of Wales Island, Alaska. 


\section{CONTENTS (cont.)}

FIGURE 1. Location of study area, Prince of Wales Island, southeastern Alaska.

2. Accordant ridge tops showing the preglacial terrane, looking southeast from near the top of Green Monster Mountain

3. Sketch of two large dolomile boudins surrounded by marble (Wm), north shore of West Arm.....

4. Wales Group green tuffaceous schist along the shore on the north side of Keete Inlet, near the entrance.

5. Photomicrograph of Wales Croup green tuffaceous schist (Wg) west shore Hetta Inlet.

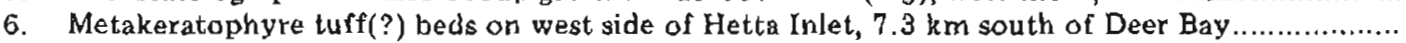

7. Photomicrograph of metakeratophyre tuff(?) from bed about $30 \mathrm{~cm}$ thick shown in fig. 6 (crossed nicols).

8. Photomicrograph of metakeratophyre crystal(?) tuff from south shore of Deer Bay (crossed nicols).

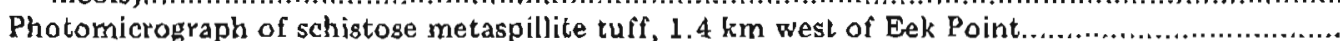
Photomicrograph of metakeratophyre tuff(?), $0.5 \mathrm{~km}$ north of Nutkwa Inlet........................... Migmatitic gneiss on northeast side of Sunny Cove, $2 \mathrm{~km}$ northwest of Sunny Point....

Descon Formation sheared conglomerate of the Odsg unit with red argillite and graywacke pebbles in a sheared argillaceous matrix.

Descon Formation banded mudstone and graywacke with floating mudstone fragment (part of Odm unit), east shore of Klakas Inlet near outlet from Klakas Lake..

Silurian crackled alaskite cemented by dolomite...

Devonian stratigraphic section between Klakas and Keete Inlet (thicknesses are approximate)..... Devonian argillite and siltstone ( $\mathrm{Da}$ ).

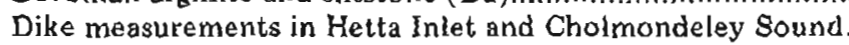

Attitudes of 292 dikes along shoreline of Hetta Inlet north of Hetta Cove.

Attitudes of 108 dikes along Sauth and West Arms, Cholmondeley Sound.

Migmatite from the marginal zone of the Copper Mountain pluton.

Epidotized gabbro on the ridge west of Lake Marge

Foliation surface in Wales Group green schist...

29. Silicious Wales Group Schist near Summit Lake.

24. Alkali-silica diagram for Hawaiian basalts (after MacDonald and Katsura, 1964) and two analyses of Descon basalt ( $\mathrm{Odb}$ ) from Klakas Inlet.

Alkali-F-M diag information

26. Alkali-F.M diagram

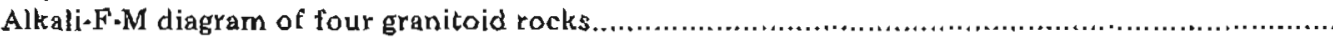
Cumulative frequency plot for copper in stream-sediment and soil samples.

Cumulative frequency plot for lead.

Cumulative frequency plot for zinc....

Parallel and crosscutting quartz deformed by gliding along foliation planes, South Arm. Cholmondeley Sound....

34. Alask a Copper Company open cut gouthwest spur of Copper Mountain

35. Sketch map of mineral zone, west side of Green Monster Mountain

36. Geologic sketch map of Summit Lake prospect (locality 14, pl. 1).

37. Geologic sketch map of the Corbin mine workings, east side of Hetta Inlet (locality 12, pl 1)...

38. Metakeratophyre bed (Krat) and underlying quartz sericite schist in hanging wall of Copper City Mine.

39. Geologic map of Copper City mine (locality 20, pl. 1)

40. Geologic map of Lime Point barite deposit (locality 21, pl. 1

41. Geologic sketch of the Moonshine Group

42. Geologic map of the Moonshine mine (locality 26, pl. 1). 


\title{
GEOLOGY AND GEOCHEMISTRY OF THE CRAIG A-2 QUADRANGLE AND VICINITY, PRINCE OF WALES ISLAND, SOUTHEASTERN ALASKA
}

\author{
By
}

\author{
Gordon Herreid, ${ }^{1}$ Thomas K. Bundtzen, ${ }^{1}$ and Donald L. Turner ${ }^{2}$
}

\section{SUMMARY}

The Craig A-2 quadrangle, on the southern part of Prince of Wales Island, contains copper deposits and anomalously old layered rocks, which include the Wales Group, the oldest known unit in southeastern Alaska. The Wales Group is about $3,400 \mathrm{~m}$ thick in the western part of the area. It contains varying amounts of marble, tuffaceous schist and phyllite, metakeratophyre tuff(?), metaspillite, quartz sericite schist, migmatitic gneiss, and slightly recrystallized limestone and phyllite. A trondhjemite dated at $730 \mathrm{~m} . \mathrm{y}$. intrudes the Wales Group (Churkin and Eberlein, 1977), providing evidence that the group is Precambrian. The date of cessation of the most recent regional thermal event affecting Wales Group rocks was determined to he about $475 \mathrm{~m} . \mathrm{y}$. B.P. (Turner and others, 1977).

In fault contact with the Wales Group are marine turbidites of the Descon Formation, which has been faunally dated west of the map area as Middle to Late Ordovician (Eberlein and Churkin, 1870). The Descon Formation in the study area consists of an $8,000-\mathrm{m}$ thick section of unmetamorphosed turbidite, graywacke, mudatone, and basalt. Calc-alkaline granitoid rocks with a minimum age of $421 \mathrm{~m} . \mathrm{y}$. (Turner and others, 1977) apparentiy intrude the Descon Formation near Max Cove.

After folding and deep erosion, the Descon Formation and associated intrusives were overlain by over $2,500 \mathrm{~m}$ of Middle Devonian sedimentary rocks. This section contains locally derived basal conglomerate, gray mudstones, green graywacke, pebble conglomerates, and minor limestone. These Devonian sediments are capped by andesite flows and andesite breccia of probable Devonian age. A conjugate system of numerous steeply dipping dikes of intermediate and matic composition intrudes the bodded rock units.

Granodiorite plutons in the area have ${ }^{40} \mathrm{~K} \cdot 40_{\text {Ar ages }}$ averaging $102 \mathrm{~m} . \mathrm{y}$. ('Turnex and others, 1977). Other Cretaceous plutons include altered diorite, alaskite, and gabbro. No matic or intermediate dikes are believed to cut the Cretaceous intrusives.

Crenulations and minor folds near the base of the Descon Formation and in the Wales Group indicate that there have been two periods of penetrative deformation. The last major folding episode occurred be-

\footnotetext{
1 Alask DGGB, College, AK 99708.

${ }^{2}$ Geophysical instlute and Solid-Earth selences Program, Universtiy of Alaska, Fairbarks, AK 99701 .
}

tween post-Middle Devonian and pre-Cretaceous time. A prominent thrust fault cuts Middle Devonian sedjmentary rocks and is in turn penetrated by a Cretaceous granodiorite pluton. High-angle faults are widespread. A set of northeast-trending high-angle faults is cut by a younger northwest-trending high-angle fault system. These faults are responsible for many of the pregent-day topographic lineaments in the study area. Low-angle thrust faults are not clearly reflected by topography.

During Pleistocene time, the area was covered by an ice sheet. The glacial topography is preserved today as accordant ridges and scattered higher hills of resistant rock. Whsconsin-age valley glaciers have carved classic U-shaped depressions in the valleys, and glacial till covers most of the bedrock there. Today the area has steep, heavily forested slopes and long, deep fiords.

The principal productive mineral deposits in the area are skarns containing copper, zinc, molybdenum, and gold around the Copper Mountain pluton (Cretaceous). The largest known deposit, the Jumbo Mine, produced $10,194,264$ lb of copper, 87,778 oz of silver, and 7,676 oz of gold during the first part of the century (Kennedy, 1963). Museum-quality epidote and quartz crystals have been won from the skarns around the pluton. Several small copper-zinc-gold deposits (Corbin, Copper City, Keete, and Nutkwa Lagoon mines) in the Hetta Inlet area occur as sulfide zones parallel to folia. tion and associated with bimodal sodic volcanism in the Wales Group. The deposits, which are all in about the same stratigraphic position, probably represent stratiform volcanogenic mineralization. Along the South Arm of Choimondeley Sound lead, zinc, and silver vein deposits, lenses, and disseminations occur near large siliceous zones in the Wales Group. Two deposits are not near intrusive exposures and could be partly remobilized stratiform deposits. Dolomite deposits are of variable age, occurring as older boudins in the Wales Group and younger remobilizations along faults associated with mafic dikes. Many quartz veins were formed before the end of regional penetrative deformation and are preserved at thickened hinges along fold axes. Younger vonfolded quartz veins fill high-angle fractures and are sometimes mineralized'with sulfides.

Throughout the area 1,270 stream-sediment, soil, and rock samples were collected and analyzed by atomic absorption spectrophotometry (Cu-Pb-Zn) and by emission spectrography (30-element scan). Stream-sediment fractions ( -80 mesh) show copper anomalies in the Hetta Inlet area and strong lead, zinc, beryllium, zirconium, and silver anomalies along Cholmondeley Sound. 
Distinct rare-earth anomalies in the Kassa Inlet area are probably the geochemical signature of the Devonian(?) volcanic rocks there. Some of the anomalies found in the study area may be the geochemical signature of undiscovered mineral deposits.

\section{SCOPE OF PRESENT INVESTIGATIONS}

This report summarizes three field seasons of a geologic mineral appraisal in a well-known copper mining djstrict on Prince of Wales Island west of Ketchikan. Field work began in 1970 and was completed in 1972. Geologic mapping of about $720 \mathrm{~km}^{2}$ was com. pleted at 1:40,000 scale (fig. 1). Geologic field assistants were J.C. Pray and T.K. Bundtzen. Marilyn Herreid worked gratis as boat handler, expeditor, and cook all three seasons. Most of the stream-sediment samples were taken by Pray and Bundtzen. During the latter part of the work, both did much detailed mapping around Copper Mountain, Cholmondeley Sound, and Kassa Inlet. D.L. Tumer of the University of Alaska Geophysical Institute joined the field party in 1972 and collected $40_{\mathrm{K}-{ }^{4}} \mathrm{Ar}$ age dating samples, the results of which have been published (Turner and others, 1977).

The generally excellent outcrops along shores of inlets and lakes were mapped with the aid of two 13-foot inflatable boats. Geology along the shore was plotted from 1960 U.S. Forest Service 1:20,000-scale black-andwhite aerial photographs. Foot traverses along the shore were difficult. Mapping above timberline was done on foot from air-supported spike camps and helicopter landings. Steep valley walls account for a large percentage of the area and are accessible only on foot. Although much of the bedrock is covered with moss, berry bushes, 'devil's club,' trees, and glacial till, out-

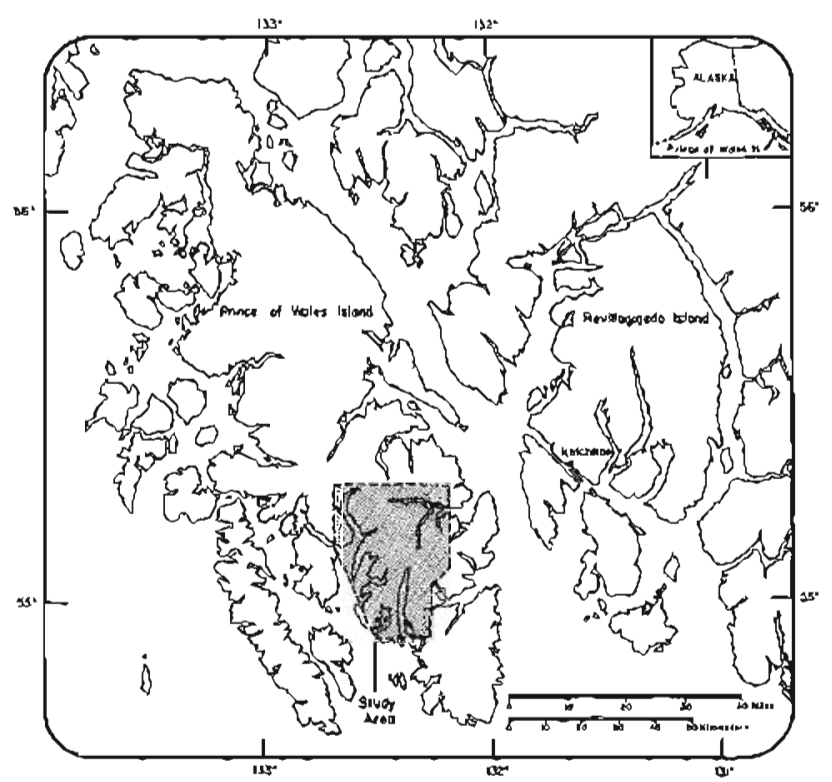

Figure 1. Location of study area, Prince of Wales Island, southeastern Alaska. crops along small creeks, beneath roots of wind falts, and along cliffs provided valuable data during geologic mapping.

In this report, linear dimensions have been expressed in the metric system; however, the English system has been retained for weights and altitudes. During discussion of rock units, the reader is referred to the geologic map (pl. 1).

\section{PREVIOUS INVESTIGATIONS}

Brooks (1902) looked briefly at prospects on Cholmondeley Sound and Hetta Inlet in 1901 and described the history of prospecting in southeast Alaska. From 1905 to 1908 the Wright brothers made wide-ranging geological investigations in southeastern Alaska. They produced a reconnaissance map of the Copper Mountain area (Wright and Wright, 1906), reported developments in the area (Wright, 1907, 1908), and published a reconnaissance report on the Ketchikan and Wrangell mining districts that contained a 1906 geological map of the Copper Mountain area (Wright and Wright, 1908). Detailed mapping by C.W. Wright in 1908 was later published (Wright, 1915); his work also includes a regional reconnaissance map of southeastern Alaska.

Chapin $(1916,1918)$ briefly described mineral prospects at Keete Inlet, Nutkwa Lagoon, Green Monster Mountain, and the areas northeast of Sulzer. Buddington and Chapin (1929) showed the area on their 1:500,000 geologic map of southeastern Alaska. Twenhofel and others $(1949$, p. 17-20) described the prospects at Lime Point and Nutkwa Lagoon. Kennedy (1953) contributed an excellent geologic study of the origin of the skam deposits in the Jumbo basin. Condon (1961) composed a useful geologic map of the Craig $1: 250,000$ quadrangte from previous sources of information and his own aerial photographic interpretation. Eberlein and Churkin (1970), Churkin and others (1970), and Churkin and Eberlein (1977) have provided valuable fossil and radiometric age control for the area.

\section{GEOGRAPHY}

The area mapped is part of Prince of Wales Island, the largest island in southeastern Alaska; the eastern border of the map area is about $50 \mathrm{~km}$ west of Ketch. ikan (fig. 1). The area is composed of steep, heavily forested mountains and long ocean fiords. Inlets include Klakas, Hetta, Kassa, Nutkwa, Keete, and the West and South Arms of Cholmondeley Sound (hereafter referred to simply as "West Arm" and "South Am"). Copper Mountain, 3,916 feet above sea level, is the highest peak on Prince of Wales Island.

A crude pattern of land forms in the map area are due to erosion of a structurally complex terrane. Klakas Inlet and South. Arm are allgned along a major northtrending fault, whereas the upper reaches of Hetta tnlet and West Arm are aligned with the West Arm fault. Several of the Larger north-northwest-flowing creeks are 
localed in fracture zones. Uplands are made of resistant rock such as intrusives and siliceous schisls. In some areas, sinkholes form an interconnecting network of hazardous, steep-walled pits, 6 lo $35 \mathrm{~m}$ in diamcter. In areas covered by vegetation, these pits indicate that the bedrock is marble or calcareous schist.

Accordant ridge tops throughout the area are remnants of an older surlace of moderate relief (fig. 2) that las been scoured by a Pleistocene ice cap and subsequent valley glaciers of Wisconsin age (Pewe, 1975). Modern stream valleys are classic U-shaped glacial valleys wilh lakes and bogs in bedrock depressions and are mantled with up to several meters of till.

The ocean inlets (fiords) are glacial troughs with floors extending several hundred leet below sea level. Except where major streans drain into inlels, the shores are steep and have abundanl bedrock exposures.

The dimate is cool and wet. In January the mean daily minimum temperature is $30^{\circ} \mathrm{F}\left(-1^{\circ} \mathrm{C}\right)$; in July the mean daily maximum is $64^{\circ} \mathrm{F}\left(18^{\circ} \mathrm{C}\right)$. The mean annual precipilation is $406 \mathrm{~cm}$ (160 inches) (Wahrhaflig, 1965).

Principal industries are logging and fishing, and in the past, mining. Small percentages of the available commercial slands of Sitka spruce, hemlock, and cedar have been logged. Commercial salmon, halibut, and shrimp lishing occurs mainly in Hetta lnlet. At the turn of the century, several mineral deposits, most notably the Jumiso Mine, were mined for copper, silver, lead, and gold.

The area is accessible by boat and aircraft from Ketchikall. Roads and tralls are rave; there are shorl logging roads near Miller Lake on South Arm and north of Jumbo Creek on Hella lnlet. Ruins of an old corduroy wagon road from Hetta Inlet lo West Arm were still in existence in 1972. At the Jumbo Mine. a $3 \cdot \mathrm{km}$. long irail from the lower adil to the beach is in fairly good condition. The remains of the old aerial tram at Jumbo were still visible.
'There are lew permanent residents in the area. Hydaburg, a small fishing village, is $13 \mathrm{~km}$ northwest of Eek, on Sukkwan Strail. The Alaska Department of Fish and Game maintains weirs on creeks draining into Hetta Cove, South Arm, and on KJakas Lake, a king-salmon spawning area. David Drury had a small semipermanent logging camp on the east shore of South Arm. In the pasl, coastal Indians chipped desigus on boulders along the beach. These petroglyphs can be found along Helta Inlel in the tidal zone.

\section{GEOLOGIC UNITS}

\section{WALES GROUP}

\section{INTRODUCTION}

Brouks (1902) named the regionally metamorphosed rocks (marble, phyllite, and schist) on Prince of Wales Island the Wales Series and considered them to be probably Silutian or older. Many of the rocks he origimally included in this unit are now mapped as Ordovician, Silurian and, near Ketchlkan. Mesozoic. Buddington and Chapin (1929) mapped unfossiliferous regional metamorphic rocks as Wales Group of "probable Devonian to pre-Ordovician age," and attempted to exclude Ordovician and younger rocks whenever pos. sible.

In this report the more strongly metamorphosed rocks are classified as Wales Group. They contrast with nonfollated Middle Ordovician Descon Formation and Devonian and younger bedded rocks nearby. All of the Wales Group rocks in the area mapped appear to have had the same metamorphic history, but could include rocks of different ages. In the vicinity of Eek Point near the western edge of the map area (pl. 1), Wales Group schists and melakeratophyre may grade upward, with a gradual decrease in metamorphlsm, into the rocks of the

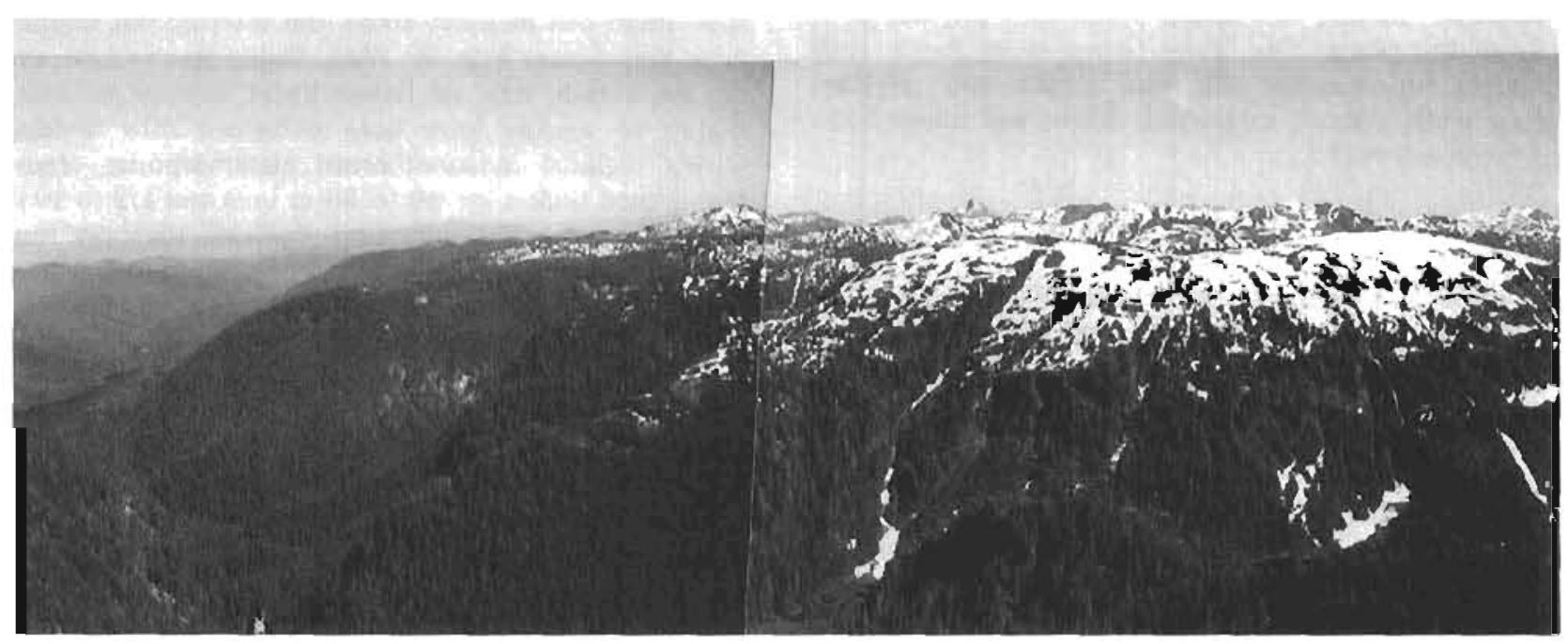

Figure 2. Accordant ridge tops showing the preglacinl lerrane, looking southeast from near the top of Gieen Monster Mountain. West Arm is on the left. 
Descon Formation. The gradual nature of this transition makes the exact placement of the Descon-Wales contact difficult. Because green schists ${ }^{3}$ and metakeratophyres were inapped to the western boundary of the mapped area, the problemmatical Descon-Wales contact was not delineated during this study. In the east-southeast portion of the area, the Wales Group is thrust under the Descon Formation along the Keete thrust.

The Wales Group is a thick pile of volcanogenic turbidite, mudstone, tholeitic(?) marine keratophyre, and related volcanic rocks and carbonate that have undergone greenschist-facies metamorphism (Winkler, 1967). It varies in composition over its aerial extent (pl. 1).

On the west, near Eek Point, the Wales Group is predominantly green tuffaceous schist and dark-gray phyllite. Scattered metakeratophyre beds make up to 15 percent of this section. Near Deer Bay metakera. tophyre and metakeratophyre lapilli\{?) tuff are of mappable size. Occasional beds of mafic metavolcanic rocks, marble, siliceous schist, and quartz, sericlte schist are present in the section. Near Corbin Point a $300-\mathrm{m}$. thick section of quartz-sericite schist overlies the green tuffaceous schist unit. Between Eek and Corbin Points the Wales Group section is about $3,400 \mathrm{~m}$ thick. These units extend southeast into Kassa Inlet. Near Hetta In-. let this entire section is overlain by a thick thrust sheet of Wales Group marble and dark-gray phyllite.

To the east along the south side of West Arm, metafelsite beds and megascopic albite grains in the Wales Group section pinch out at the entrance of South Arm. In addition, metabasalt nows increase in abundance in the Wales Group section eastward from Hettr Inlet to South Arm. Rocks on the north and south sides of West Arm are displaced by the West Arm cault. On the north side of the fault the Wales Group consists largely of homogeneous green-gray schist without megascopic albite, whereas on the south side the mafic metavolcanics, marble, and green schist and phy!lite constitute the group. The Wales Group along South Arm consists of abundant siliceous schists and phyllite, green schist without megascopic albite, and minor basic metavolcanic rocks.

\section{MARBLE (Wm)}

Marble is a distinctive unit in the Wales group. Thin marble beds are interbedded with the Wales Group schlsts throughout much of the map area. South of West Arm a thrust sheet consists of marble and minor green schists.

Most of the marble is very light to medium-gray finegrained crystalline rock that weathers medium gray. Near intrusive contacts it is recrystallized into a coarser grained very light gray rock. In some areas it has thin

\footnotetext{
${ }^{3}$ In this report the tarm 'greenschisi' means mafic meta-ignoous rock that has a schistose texture. 'Green schist' is a schist with a distinctive green color but is nat necessarlly metaigneous.
}

color or composition bands parallel to bedding; elsewhere it is massive with no hinl of beoding on fresh surfaces. Minor folds within marble beds are common. Beach outcrops are pitted by solution. Intersecting solution pits up to $30 \mathrm{~m}$ in diameter and $10 \mathrm{~m}$ deep in upland areas make foot travel hazardous, particularly west of Big River.

In some areas medium-gray fine-grained marble with dolomitic nodules contains a large percentage of crosscutting, very light gray crystalline calcite velnlets with sharp contacts. The rock imperceptibly grades into a very light gray crystalline marble with no dolomitic nodules. In other areas very light gray marble and medium-gray limestone occur close enough to suggest that the color change is not due to metamorphism. An aureole of very light gray crystalline marble up to $200 \mathrm{~m}$ wide is present around the Copper Mountaln pluton, suggestive of recrystallization by the intrusive.

Buddington and Chapin (1929) report finding "possible coral Pragments" of Sllurian appearance at Limc Point. Neither we nor Eberlein (pers. comm., 1972) found any fossils during ficld work in Wales Group rocks. The marble (Wm) and dark gray phyllite (Wp) in the upper thrust plate at the north end of Hetta Inlet make up a major member of the Wales Group. Wm and Wp may be younger than the Wales Group rocks on Hetta Inlet and Sukkwan Strait, since units there underlic(?) them.

\section{DOLOMITE-RICH MARBLE (Wdm)}

Dolomite-rich marble crops out at Hetta Inlet and in the Blg River thrust sheet on West Arm. Similar-appearing but less extensive replacements(?) of marble by dolomite exist in the Wales Group on South Arm.

On the north shore of West Arm dolomite forms thick, planar, fine-grained medium- to-light-gray beds that stand out in relief above the intorlayered marble. Near the contact with the Wales Group green schist, and on the islands west of Sunny Point, tabular dolomite bodies in marble have been deformed into boudins during regional dynamothermal metamorphism. These lens.shaped bodies are 10 to $30 \mathrm{~m}$ long and $1 / 2$ to $10 \mathrm{~m}$ thick. Ridges and terminations Indicate that the long axes of the boudins plunge steeply 45 to 80 degrees southwest. Elsewhere there are highly irregular dolomite. bodies that stand up in reliel on shoreline outcrops (fig. 3), Usually, irregular, folded dolomite bodies have marble beds draped around them, suggesting deformation of the rocks after deposition of the dolomite.

On the north shore of Divide Head, dolomite in marble forms thin partings parallel to bedding and small subangular lumps several centimeters across. In a few places there are many dolomite veinlets crosscutting the marble.

On the west shore of Hetta Inlet a thick marble bed in the phyllite-marble-green schist (Wpmg) $1 / 2 \mathrm{~km}$ south of Perry Creek las rounded irregular masses of 


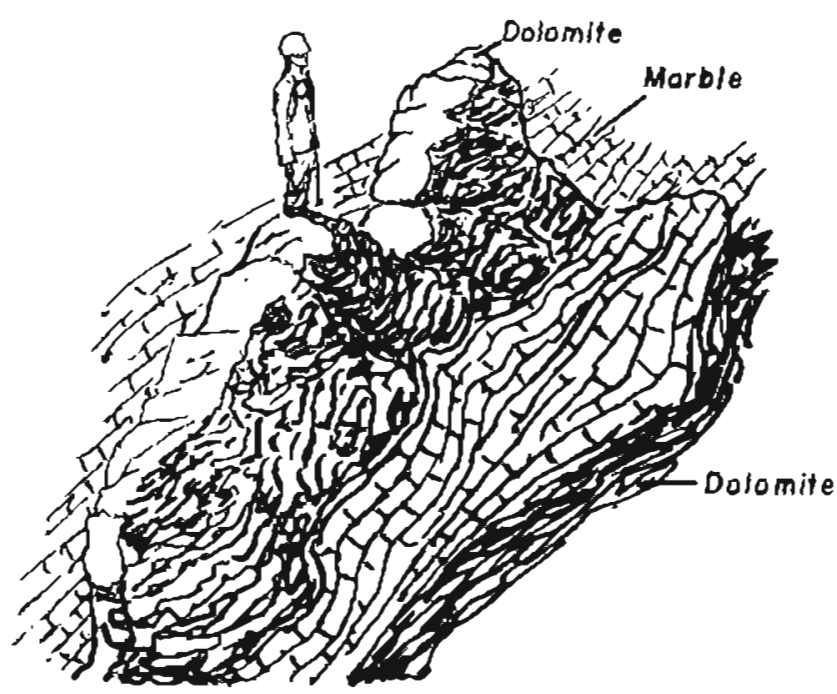

Figure 3. Sketch of two lange dolomite boudins surrounded by marble (Wm), north shore of West Arm.

pinkish-gray dolomite up to $1 \mathrm{~m}$ thick. These are somewhat elongated with the enclosing marble and show evidence of plastic llow. The rock is essentially identical to dolomite-rich marble units on West Arm.

\section{DARK-GRAY PHYLLITE (WP)}

Phylite is a major unit of the Big River thrust sheet and of the northern portions of Hetta Inlet, near Gould Island, where it is interbedded with thick beds of marble. It is also present in the hornfels zone southeast of Dell Island. Scattered beds of phyllite occur along West Arm (included with the Wpmg unit) and adjacent to a fault zone on the west shore of Nutkwa Inlet.

This rock unit has finely crenulated foliation surfaces and commonly cleaves into 2-cm-thick plates. It is dark gray and line size except in shear zones, which have many deformed quartz veinlets.

\section{PHYLLITE, MARBLE, AND GREEN SCHIST (Wpmg)}

This is a heterogeneous unit of the Wales Group that consticutes all the islands in West Arm. It occurs on the south shore of West Arm and makes up a similar lithoiogy on Hetta Inlet. These rocks are greenish- to darkgray phyllite, greenish-gray, llmy, sericitic tuffaceous schist with twinned albite crystals, and marble. Unit Wpmg overlies the marbie (Wm) and dark-gray phyllite (Wp) in the Big River thrust sheet.

\section{GREEN TUFF ACEOUS SCHIST (Wg)}

Green tulfaceous schist is the most abundant rock along Hetta and Kassa inlets (fig. 4) forming great thicknesses of well foliated greenlsh-gray schist, interbedded with occasional metakeratophyre, and basic metavolcanic layers $1 / 4$ to $3 \mathrm{~m}$ thick. West of Eek Point the rocks grade into green and gray albite-bearing phyllites of identical composition.

The green tuffaceous schist is typically greenish gray to greenish black, fine grained with thin lenticular alternating quartzose and chloritic layers that range from $1 \mathrm{~mm}$ to several centimeters thick. The rock commonly contains a scattering of white $1 / 2$-to 3 -mm-long grains of albite that make up as much as 5 percent of the rock. The foliation swirls around the grains, indicating that' they formed prior to the end of deformation. The folia. tion of the rock is due to the platy orientation of chlorite flakes. Almost everywhere foliation is parallel to composition bands in the green-schist and metakeratophyre beds.

The rock is believed to have originated as chloritic mudstone with a scattering of albite grains of tuffaceous origin (fig. 5). The minerals present are quartz, large subangular twinned albite (An 0 to 5), chlorite, carbonate, iron ore, leucoxene, and very minor actinolite. Biotlte is rare, except in thermally metamorphosed rocks.

On the west shore of Hetta Inlet, shearing is more pronounced than recrystallization. Deeper in the section, on the east shore of Hetta Inlet, recrystallization has resulted in a more schistose fabric. Here the albite crystals have lost their lath shape and become part of an in. creasingly equant-grained granoblastic fabric. Large, twinned albite grains are preserved even in the rocks with granoblastic matrix, but it is not possible to differentiate tuffaceous mudstone from porphyritic metakeratophyre tuff once the albite has been recrystallized to granoblastic grains.

\section{METAKERATOPHYRE TUFF(?) AND RELATED ROCKS (K, Kxt, Kd)}

Beds of metakeratophyre tuff(?), metakeratophyre nows, and metaspllite occur in the green tuffaceous schist (Wg) of the Wales Group, particularty in the northern shores of Hetta Inlet and Sukkwan Strait near Eek Point. When of mappable size, these rock types are found on plate $I$ as subunits within the green tuffaceous schist $(\mathrm{Wg})$. On the east shore of Hetta Inlet and on Kassa Inlet they are somewhat less abundant. The rhyolite unit mapped in the Jumbo Basin by Kennedy (1953) is metakeratophyre. To the east on the West an South Arms, there is only minor green tuffaceous schist (Wg) and almost no metakeratophyre tuff(?) and related rocks.

Metakeratophyre turf(?), the dominant metavolcanic rock type, occurs as consplcuous, nearly massive porphyritic metafelsite beds $1 / 4$ to $3 \mathrm{~m}$ thick in green tuffaceous schist and phyllite and rarely makes up more than 10 percent of any particular section of the Wales Group (fig. 6). These beds parallel foliation and layeting in the Wales Group schists and have contacts that range from sharp to gradational over a lew centimeters. The metakeratophyre beds, usually light to medium gray, 


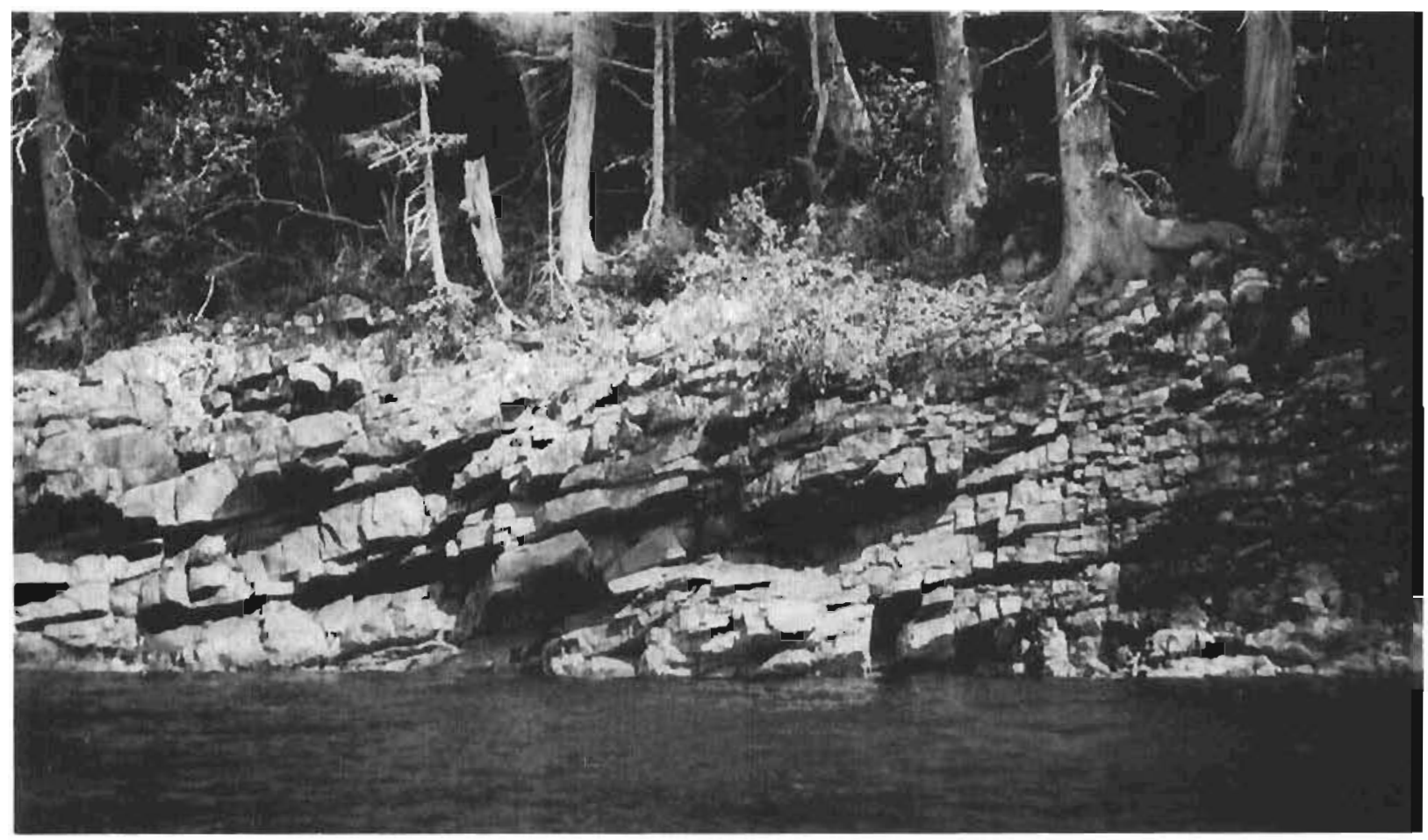

Figure 4. Wales Group Hritn tuffaceous schist along the shore on the north side of Keete Inlet. near the entrance.

sometimes lake on a green or blue hue because of theis chlortle content. The unfoliated or slightly foliated metafelsite usually contains about 3 percen l macroscopic albite phenocrysts. A smaller percentage of megascopic quartz anhedra are usually present. The metakeratophyre tuff(?) beds are more brittle than the enclosing green. schist beds and are slightly stretched as a result. Fractures that formed in the metakeratophyre beds during brittle deformation are often filled with quartz veinlets. The megascopic evidence for the luffaceous origin of the felsic beds is their appurnt igneous lexture (blastoporphyritic metafelsite) and their thinness ( $1 / 4$ to $3 \mathrm{~m}$ ).

A photomictograph of metakeratophyre tuf?(?) ([ig. 7) shows the distinctive albite phenocrysts in a finer grained matrix. The albiles are $1 / 2$ to $3 \mathrm{~mm}$ long, often euhedral, but show slightly ragged borders. They often form in groups of several crystals that display complex lwins that form a checkerboard pattern. Bent phenocrysts are somelimes present. The albite microlites(?) in the groundmass have albite twinning and ragged borders, are lath shaped (length to width ratio up to $10: 1$ ), and may be tracliytic. Otirer minerals that make up the groundmass are equant quartz grains, chlorite tlakes and veinlets, carbonate, magnetite(?), and leucoxene,

Blastoporphyritic metakeratophyre lapilii(?) Lurf forms thin beds on the east shore of Nutkwa Inlet. A typical than section shows albite phenocrysts(?) wilh carlsbad and albite twinning and ragged borders. The groundmass consists of quart $z$, albite, chlorite, opaques, and leucoxene. Twinned albite microlites(?) surround the pisenocrysts(?) in a trachytic or fluidal patlern. Because the beds are thon $(\leq 1 \mathrm{~m})$, this texture may have originated as turf. 'Tle curt fragnents are large enough (up to $3 \mathrm{~cm}$ ) to preserve a primary igneous texture. Outer botders of the lapilli(?) are only rarely preserved and generally not visible.

Along the north and south shores of Deer Bay (pl. 1)

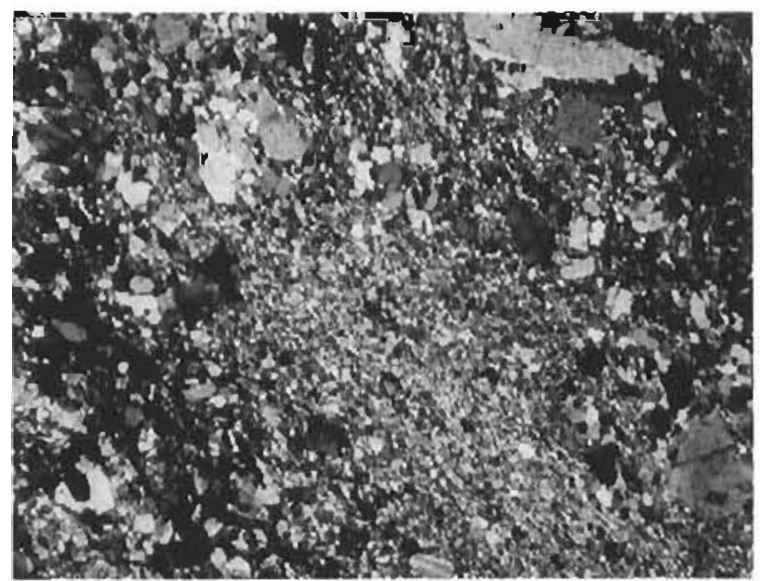

Figure 5. Pholomicrograph of Wales Group green tuf. faceous selsist $\left(W_{g}\right)$, west shore, Hella Inlel. Sheared lapilsi in a fine-grained matrix has produced a blastoporphyritic lexture. 


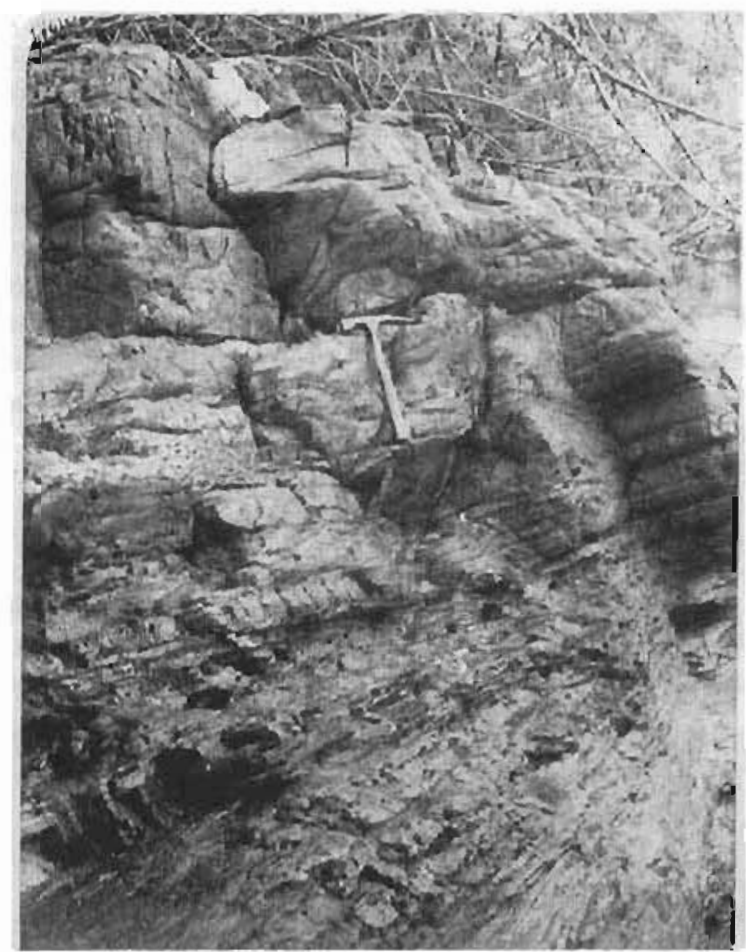

Figure 6. Metakeralophyie tuff(?) beds on west side or Helta Inlec, $7.3 \mathrm{~km}$ south of De(r) Bay. The rock below the pick is green tuf faceous schist (Wg).

are several graded crystal tuff(?) (Wkxt) beds up to 30 $m$ thick that range from conrse fragmental rock at the base to fine-banded green-gray phyllite at the top. Figure 8 shows a photomicrograph of a metakeratophyre crystal(?) tuff from a coarse-grained basal bed at Deer

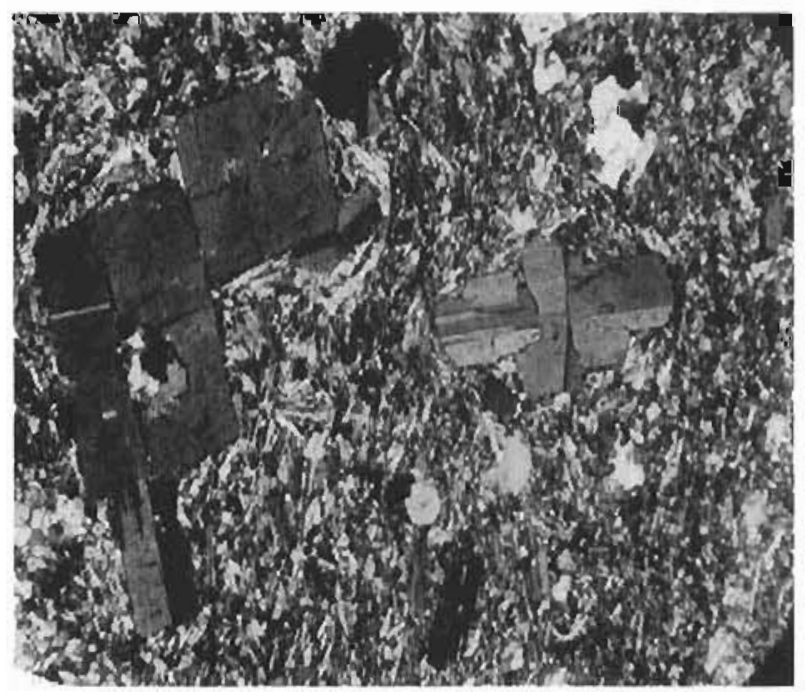

Figure 7. Photomicrograph of metakeralophyre turf(?) from bed about $30 \mathrm{~cm}$ thick show's in fig. 6 (crossed nicols).
Bay. Lapilli(?) fragments containing complexly twinned albite crystals occur in a chlorite-rich matrix and likely originated as a pyroclastic accumulation.

Green chloritic metakeratopliyre flows crop out over a width of $300 \mathrm{~m}$ in a cove west of Eek Point. They are bluish- to dark-greenish-gray phyllitic anygdaloidal porphyrilic metalelsites. Twinned, dusty abite phenoblasts $\left(\mathrm{An}^{-3}\right.$ ) are up to $3 \mathrm{~mm}$ long. Almono-shaped amygdules up to $1 \mathrm{~mm}$ in cliameter are composed of fine-grained quartz, carbonate, and epidote. The groundmass in most specimens consists of subparallel twinned albite microlites(?) to $0.1 \mathrm{~mm}$ long in a field of finer grained albite, chlorite, carbonatc, and maguetite. Carbonate veinlets and pods cut the rocks. The metakeratophyre is quite similar to tuffaceous schist (Wg). but the rather well-ctystallized subparallel albite micro. lites(?) in the groundmass and the presence of amygdules indicate a volcanic flow origin.

Metaspillte hows and tuff(?) (not indicated on plate 1) are exposed on Sukkwan Strait west of Eek Poinl and on the east side of Hetta Inlet near the Copper City mine (pl. 1). About $1 \mathrm{~km}$ west of Eek Point melaspillite flows crop out over a width of $100 \mathrm{~m}$ and consist of bluishgray fine-grained rock and flowage bands, 1/2-10 2-1/2cm-long almond-shaped amygelules, and irregular metaspillite bombs up to $1 \mathrm{~m}$ long. The melaspillites in thin seclion (fig. 9) contain carlsbad-albite twinned albite and actinolite phenocrysts(?) to $1 \mathrm{~mm}$ long in a groundmass of divergent albite, chlorite, epidate, acicular actinolíte, and tiny opaque grains. The bombs are composed of epidute, ncicular tremolite, and quartz. Thin metaspillite tufr(?) beds outcropping at and near the Copper City mine are chlorite schists that contaln patches of relsite and granoblastic quartz-albite in a rock largely composed of chlorite, epidote, sericite, and magnetite.

According to Dickenson (1962), "Quartz keratophyre

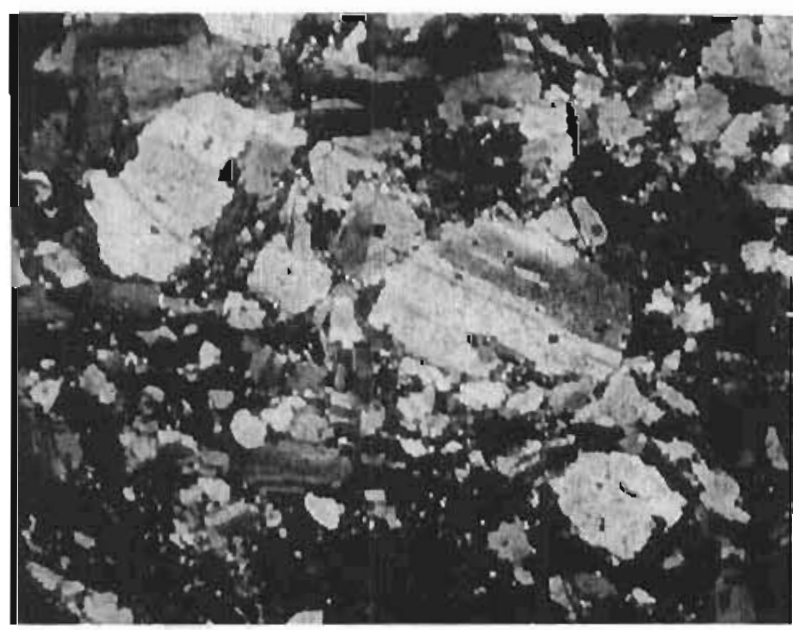

Figure 8. Photomicrograph of metakeratophyre crystal(?) tuff from south shore of Deer Bay (crossed nicols). 
may be defined as felsite or lelsophyre composed dominantly of albite and quarlz forming an interlocking groundmass mosaic of microscopic anhedral and subhedral crystals. Most quartz keralophyres that have been described carry phenocrysts of quartz and albite as well."

This description fits the metakeralophyres in the Wales Group, except that the original quartz phenocrysts may now be represented as composite groups of quartz. anhedra. In addition, albite phenocrysts are more abundant than quartz in the Wales Group metakeralophyres.

Most of the albite phenocrysts cound in the metalelsitic and metabasaltic rocks previously described are believed to be igneous. Albite veinlets do not cut Wales Group melakeratophyres, and albite rims on the more calcic plagioclase are usually lacking. According to universal stage measurements made on 4 grains of albite from a metakeratophyre tuff(?) near Nutkwa Inlet and from 12 grains of albite from a similar locality west of Eek Point, the albite is An $2( \pm 2)$, between a high- and low-temperature state: $2 \mathrm{~V}_{z}$ on two grains ol abite from the Nutkwa Inlet locality is $87-88^{\circ}$ (fig. 10), which also suggests an intermediate thermal state. According to Donnelly (1963), these properties are typical of albite phenocrysts that crystallized in a quarlz-keratophyre melt rather than by later albilization.

Chemical analyses of five Wales Group metakeratophyre tuff(?) samples and a metaspillite tuff(?) show the distinctive sodic-rich nature ( $\mathrm{Na}_{2} \mathrm{O}$ of $4.95-6.77$ percent) of the Wales Group metakeratophyre and metasplllitic volcanic rocks. In addftion, the metakeratophyres range from intermediate to felsic compositions. Peek (1975) reported similar chemical oxide analyses from Wales Group(?) netavolcanic tuffs at Niblack Anchorage, which show Na-rich compositions.

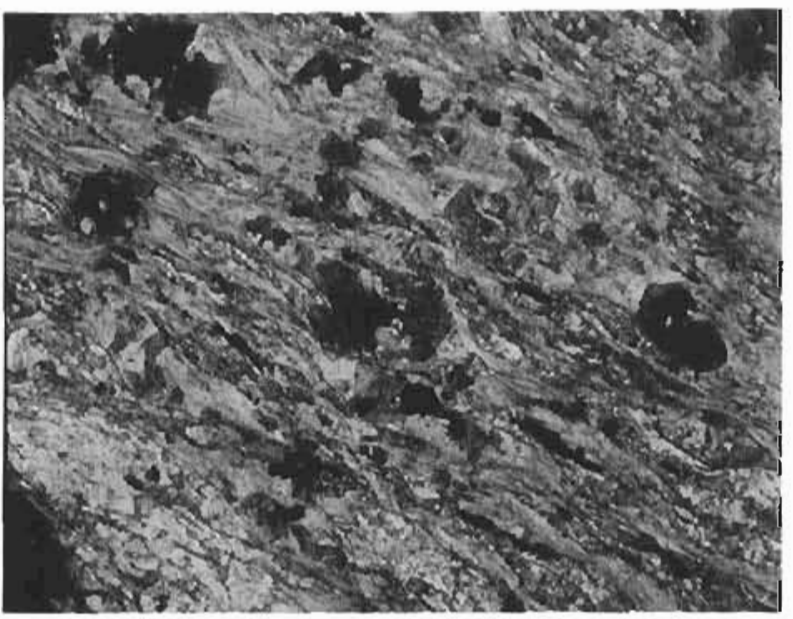

Figure 9. Photomicrograph of schistose metaspillite tuff, $1.4 \mathrm{~km}$ west of Eek Point. Colorless tremolite overgrowtiss on actinolite seen in grailus in central and left-central parts of section (crossed nicols).
A plot of the analyses on an alkal-F-M diagram (p. 28) suggests that the Wales Group metavolcanic rocks may be part of a differentialed tholeittic suite (Carmichael and others, 1974). However, dark.greenisls-gray metasedimentary phyllites and greenschists on Hetta Inlet and west of Eek Point often contain uniformly distributed albite grains in their muddy matrlxes, which indicates secondary albitization during metamorphism. Also, some of the phenocrysts in the inetaspillites and metakeratophyre probably have been albitized. Evidently there are both melamorphic and igneous albite in rocks of the Wales Group.

\section{QUARTZ SERICITE SCHIST (Ws)}

A 300-m-thick section of dark-gray quartz sericite schist (Ws) underlies Wales Group green tuffaceous(?) schist ( $W g$ ) on Hetta Inlet. This rock unit is well
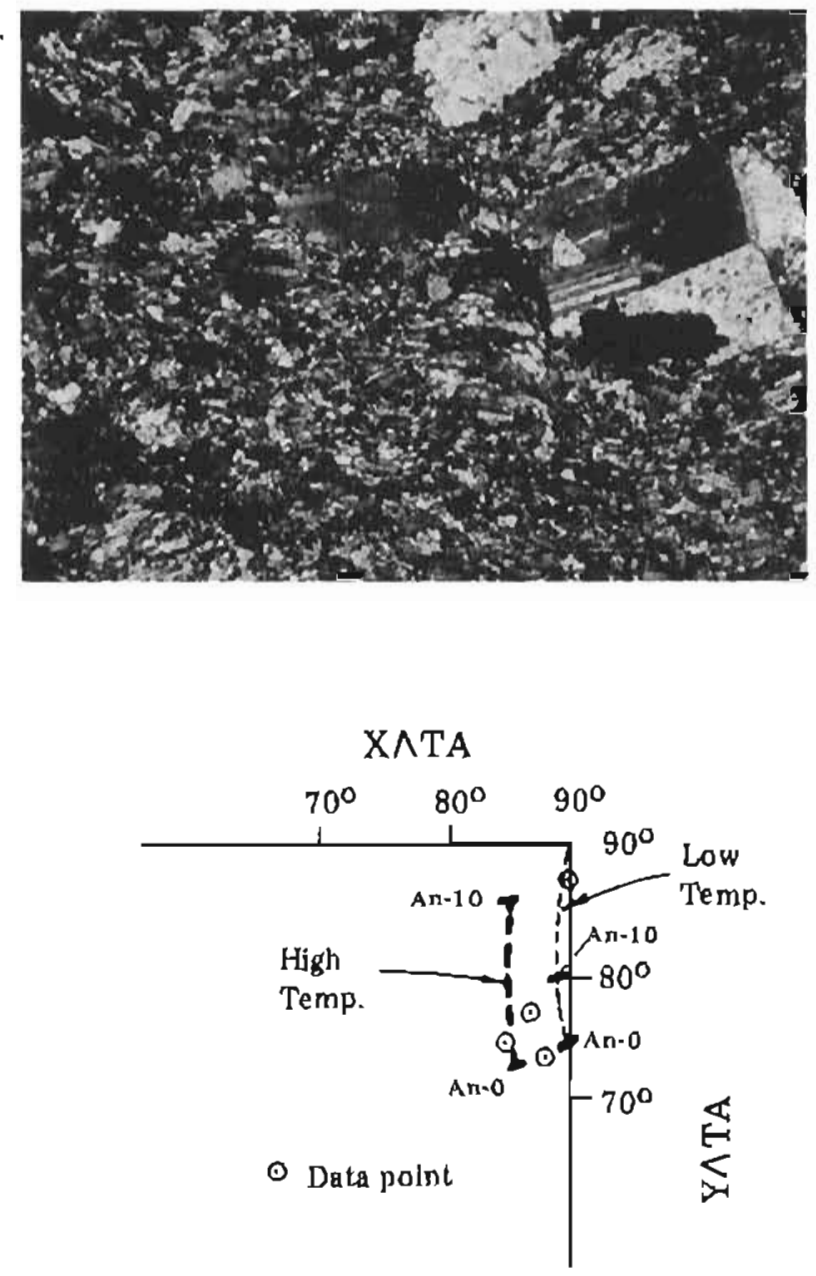

Figure 10. Photomicrograph of metakeratophyre tuff(?), $0.5 \mathrm{~km}$ north of Nutkwa Indet. Universal stage data on four grains in this section of albite are also shown. The albite twin axis measurements are plotled according to Slemmons (1962, plate 2). 
Poliated and crenulated. Locally in the schist there are marble bands a few centimeters thick. Quartz veins, many of which are less than $5 \mathrm{~cm}$ thick, parallel and crosscut foliation, and many are stretched and folded with enlargements in the hinge zones. Quartz sericite schist (Ws) on Hetta Inlet south of the mouth of Jumbo Creek is somewhat gradational with the overlying Wales Group green tuffaceous schist (Wg).

In thin section the rock is primarliy inne-gralned granoblastic quartz and minor albite, with trains and scattered aligned shreds of sericlte and chlorite and masses of carbonate; synkinematic biotite grains to 0.2 $\mathrm{mm}$ in diameter make up about 2 percent of the rock. There are a few fairly large partly sericitized albite crystals in typical rock samples. These crystals are up to $0.5 \mathrm{~mm}$ in diameter, have albite twinning, and may be related to the albile found in Wales Group metavolcanic rocks. The quartz-sericlte scluist may be a tuffaceous equivalent of some metakeratophyre flow rocks previously described. Some quartz-sericite schist zones are evidently associated wills sulfide mineralization at $\mathrm{Ni}$ black Anchoragc (Herreid, 1964; Peek, 1975) and in the study area (p. 36).

\section{SICICIFIED SCHIST (W\&s)}

Mappable zones of greenish gray to gray quartuose schist are found throughout the area, particularly near Cholmondekey Sound and Copper Mountain. Quarlz appears as veinlets and boudins that make up to 50 pey. cent of the rock. Zones associated with sulfide mineralization are discussed in the Mineral Deposits section of the report.

\section{PHYLLI'TE AND LIMESTONE (Wpl)}

A carbonate unit less metamorphosed than the Wales Group marble ( $W(m)$ is present at the south end of Divide Head. It consists of thin-bedded, medium- to dark-gray, fine- to medium-grained limestone interbanded with dark-gray slaty phyllite, crenulated green. ish-gray phyllite, and greenish-gray graywacke. Calcite veinlets, irregular quarta lenses, and dolomilized areas crosscul bedding in the unit. The Wpl unit displays distinctive granular weathering in the limestone in beach outcrops, a contrast with the hackly, pitted Wales Group marble. The phyllite beds have a more roughly weathered surface than the Wales Group green tuffaceous schist. Macroscopic folds are locally abunJant in this unit.

\section{MIGMATITTC GNEISS (Wgm)}

A banded migmatite gneiss unit is exposed along the northeast shore of Sunny Cove on the West Atm of Cholmondeley Sound. It ranges in texture from banded quartz diorite gmeiss to decussate amphibolite and fine-grained well-foliated schisl. The unit is cut by irregtłar feldspar veins ([ig. 11). The schist has kink bands geometrically identical to those in the enclosing Wales Group schists.

In thin section, the rock is seen to consist of fine. grained granoblastic albite-twinned andesine, quartz. garnet. scattered magnetite grains, and large ragged horn. blende grains with many unreplaced quartz inclusions. The hormblende is partly altered to chlorite and the feldspar is partly altered to epidole and sericite. Knotled schist $0.8 \mathrm{~km}$ from the head of Sunny Cove contains rolled, dark-green to yellow actinolite and albite augen in a fine-grained greenschist composed of quartz, albite, chlorite, epidote, actinolite, and magnetite.

The mignatitic gneiss is in intrusive(?) contact with Wales Group schist along its southeast margin. Exposures show a sharp, planar, ventcal contact without shearing that crosscuts foliation in gmeiss and Wales Group greenschist. The Wgm unit may represent a metasubvolcanic plug intrusion into green schist $(\mathrm{Wg})$ related to the Wales Group volcanism. At Sunny Cove there is no contact-metamorphosed aureole around the body of migmatitic gneiss.

\section{AGE OF THE WALES GROUP}

Published K-Ay data (Turner and others, 1977) indicate that the Wales Group was Involved in a regional

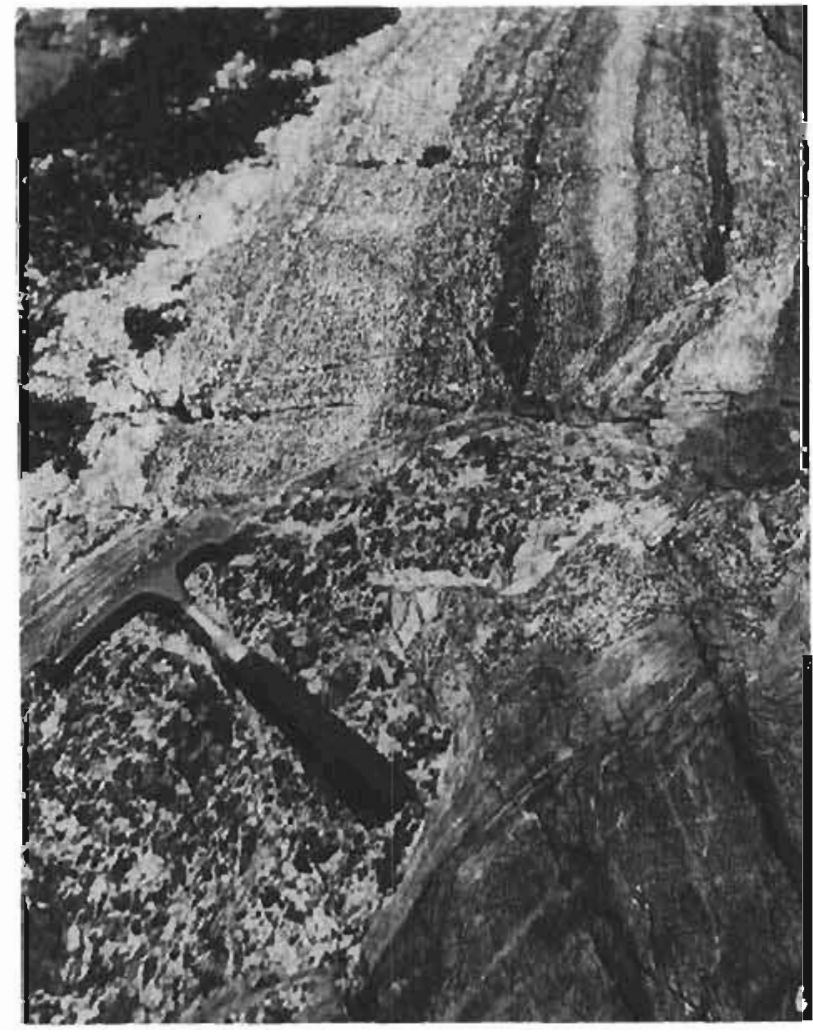

Figure 11. Migmatitic gneiss on northeast side of Sunny Cove, $2 \mathrm{~km}$ northwest of Sunny Point. The dark grains and streaks are hornblende. 
Whermal event that cooled to argon-blocking temperatures about $475 \mathrm{~m} . y$. ago. The evidence for this conclusion is shown on $40_{\mathrm{K}} 40_{\mathrm{Ar}}$ rad isochron diagram, on which are plotted homblende and tremalite data from two actinolite schists on Hetta Inlet near Eek Point, from a whole-rock metakeratophyre from the west side of Hetla Inlet, and from a mignatitic gnelss incruding the Wales Group on the West Arm of Cholmondeley Sound.

The two dated actinolite schists contain broken and rotated relict crystals of actinolite in a matrix of chlorite, albite and tremolite. The actinolites show incipient overgrowths of tremolite. These textural re. lationshlps and the presence of interbedded metakeratophyres indicate that the dated schists represent original volcanic ash layers in the Wales Group and that the relict hornblende represents a primary volcanic mineral that has partially altered to tremolite during greenschist-facies metamorphism (Turner and others, 1977).

On the basis of a preliminary $\mathrm{Pb}-\mathrm{U}$ zircon age by Saleeby, Churkin and Eberlein (1977) have reported that metamorphic rocks of the Wales Group at Ruch Bay are intruded by an undeformed trondiljemite body that is believed to have crystallized at least $730 \mathrm{~m}$.y. ago. Assuming that this age will be confirmed by additional $\mathrm{Pb}-\mathrm{U}$ dating, these workers have proposed that a greenschist-facies melamorphism in the Wales Gtoup pre. ceded the intrusion sometime during the Precambrian. Churkin and Eberlein's zircon Pb-U age was apparently unaffected by the event that resel the K.Ar system to the isochron age of $475 \mathrm{~m} . \mathrm{y}$. The radiometric age data reported by 'Turner' and others (1977) is not inconsistent with a Precambrian assignment to the Wales Group. If Churkin and Eberlein's conclusions are cor. rect, the K-Ar data Indicate that a second thermal event affected the Wales Group aiter a Precambrian(?) metamorphic event.

Eberlein (pers. comm.) found cobbles of green schist: he belleves to be of Wales Group orlgin in the Lower Ordovician Descon Formation sedimentary rocks west of the map area. During this study metakeratophyre(?) dasts were found in Descon Formation sedimentary rocks on Klakas Inlet. No fossils have heen found in Wales Group rocks thus far and we are tentatively assigning the entlre group to the Precambrian, although It may be a geologic unit thal extends into the early Paleozoic.

\section{DESCON FORMATION}

\section{INTRODUCTION}

The Descon Formation along the west side of Prince of Wales Island consists of "a thick sequence of coarse- and fine-grained maxine rocks, predominantly graywacke type with interbedded basaltic volcanics and minor limestone" (Giberlein and Churkin, 1970). Ac- cording to Eberlein (pers. comm., 1972), the rocks on the north shore of Sukkwan Strait west of the map. area are similar to the Descon Formation and are mainly andesitic mudstone, probably Middle or Late Ordovician, as shown by fossil evidence several kilometers to the nortli.

Along Klakas Inlet there is a section of uninetamorphosed Descon(?) Formation about 6,500 m thick, truncated at the base by the Keete Iniet underthrust and at the top by an angular unconformity. The oldest sedimentary rocks exposed are a sequence of about $1,000 \mathrm{~m}$ of strongly sheared but thermally unmetamorphosed flysch(?) deposits that consist of conglomeratic graywacke, siltstone, and argillite interbedded with basic volcanics rocks and marble. Overlying this sequence is about $3,500 \mathrm{~m}$ of unsheared graywacke and banded mudstone that is overlain by about $1,500 \mathrm{~m}$ of pillow basalt, which has been intruded by Silurian or older (probably Late Ordiviclan) granodiorite and alas. kile. The graywacke and banded mudstone unit is correlated with the Descon Formation graywacke dcscribed by Eberlein and Cluurkin (1970).

Graywackes, volcanic, and associated rocks on South Arm $(O d s, O d v)$ are tentatively classified with the Descon Formation. They are lithologically similar to the Descon(?) Formation on upper Klakas Inlet, althougl penetrative deformation is lacking in the section on South Arm. The unil is largely made up of massive medium-gray argillite with local thin-bedded mudstone, pebble conglomerate, spilite, and rhyolite tuff(?). A 30-m-thick unit of gray limestome is present in the section.

Clasts in Descon rormation graywackes and sillstones on South Arm suggesl deposition by mudslides or lurbidity currents. Sharp local Colding in inter[ingering silistone and pebble conglomerate indicates that slumping occurred shorlly after the time of deposition.

\section{SPILITE(?) (Ods) AND MIXED VOLCANIC ROCKS (Odv)}

Spillte(?) (Ods) crops out in two areas along South Arm. It is dark-greenish-gray, nonfoliated, and abundantly porphyritic, with albite phenocrysts to $4 \mathrm{~mm}$ Iong in a less abundant matrix of chlorite masses with fibrous zeolite(?) cores, leucoxene, and carbonate. The alblte phenocrysts are not cored by more calcic plagioclase and one clicmical analysis (table 2, No. 11) shows spilitic affinities for this malic volcanic unit (Ods).

Mixed volcanic rocks (Odv) including andesite llows and rhyolitic pyroclastic rocks are exposed adjacent to the spilite(?) (Ods) along the east side of South Arm. The andesile is medium to greenish gray and aphanitic, of ten showing pillow structures. Pillows in the andesites are 1 to $2 \mathrm{~m}$ in diameter and appear right-side up. Rhyolitic pyroclastic rocks are made up of line lithic grains (to $0.9 \mathrm{~mm}$ long) of rhyolite(?) in a matrix of 
glass, dusty iron oprques, and secondary carbonate. The rhyolite grains are feisite with abile microlites not unlike the metakeratopliyre found in the Wales Group.

Because both the spilite(?) (Ods) and mixed volcanic rocks $(\mathrm{Odv})$ lack penetrative deformation and are apparently interbedded with Descon Formation mudstones (Odm), they have been tentatively assigned to the Descon Formation. Complex laulting, however, has separated them from the Wales Group schists to the north and the major Descon Formation sedimentary units to the south.

\section{SHEARED CONGLOMERATIC GRA XW ACKE (Odsg)}

The sheared, unfoliated conglomerates, graywacke, siltstone, argillite, limestone, and minor mafic voicanics of the Odsg unit occur at the base of the Descon Formation on upper Klakas Inlet and at the end of South Arm. The conglomeratic rocks vary greatly in composition and texture. Some of the argillite has slaty cleavage, whereas the volcanic rocks and graywackes usually have none.

Typical intraformational conglomerate at the north end of $\mathrm{KJak}$ as Inlet contains rounded, unstretched clasts of Iresh porphyritic andesite and grayish-red argillite in a grayish-red slate matrix. At othey localities in the Odsg unit, greenish-gray conglomeratic gray wacke interbedded with grayish-red argillite contains floating angular andesite clasts. Figure 12 shows a typical 0 dsg conglomerate from the north west shore of Klakas Inlet.

Some conglomerates conlain very lange clasts. Along the west shore of Klakas Inlet, slaggy-weathered conglomeyatic beds with a limy matrix contain rounded basalt and marble boulders up to $1.5 \mathrm{~m}$ in diameter. Conglomeratic rocks in the Odsg unit evidently pormed in a highenergy environment, perhaps on a steep submarine slope.

The interbedded graywacke beds are massive, unsheared, greenish gray, up to $5 \mathrm{~m}$ thick, and range from silt to sand. They usually contain a subordinate amount of pebble. to cobble-sized clasts of chert, mudstone, and metavolcanic rocks.

Minor but distinctive arglllite and siltstone beds are intercalated with gray wacke and conglomerates through. out the Odsg section. They are typically greenish gray to dark gray with bands from 1 to $20 \mathrm{~cm}$ thick. Bedding. plane shear is very common, and much of the rock is often composed of sheared lenses differing silghtly in grain size and composition. A distinctive argllite variant in the Odsg section is the grayish-red beds, $1 / 4$ to $1 \mathrm{~m}$ thick, exposed at the north end of Klakas Inlet and on South Arm. These beds served as markers for mapping the Odsg section. Distinctive reddish-gray oxidized zones derived from nearly in-place noat boulders of reddish. gray argillite are found along the northern shores of Klakss Inlet at intervals of 50 lo $80 \mathrm{~m}$.

A few fragmental basalt flows both with clasts in an aphanitic matrix and without clasts are present in the
Odsg unit, particularly near the top of the section. Some basalt examined in thin section contains calcic plagioclase (An 50-70), but in others the plagioclase has apparently been albitized.

Interbedded conglomerale and marble beds are common In the upper $600 \mathrm{~m}$ of the Odsg section. At one locality a detrital marble bed contains angular basalt clasts.

The Odsg unit appears rightside up. A faulted sedimentary(?) conlact separales Odsg from the overlying Odm unil.

\section{BANDED MUDSTONE (Odm)}

Units of flyschlike banded mudstone, ranging from $10 \mathrm{~cm}$ to $300 \mathrm{~m}$ thick, are interlayered with gray wacke for about $8 \mathrm{~km}$ along Klakas Inlet. These well-bedded unsheared rocks are in sharp contrast to the underlying, pervasively sheared, poorly bedded Odsg unit.

The banded mudstone unit is composed of thin rhythmic beds of sillstone and argillite 0.5 to $10 \mathrm{~cm}$ thick, with occasional thicker beds of graywacke. Silt-

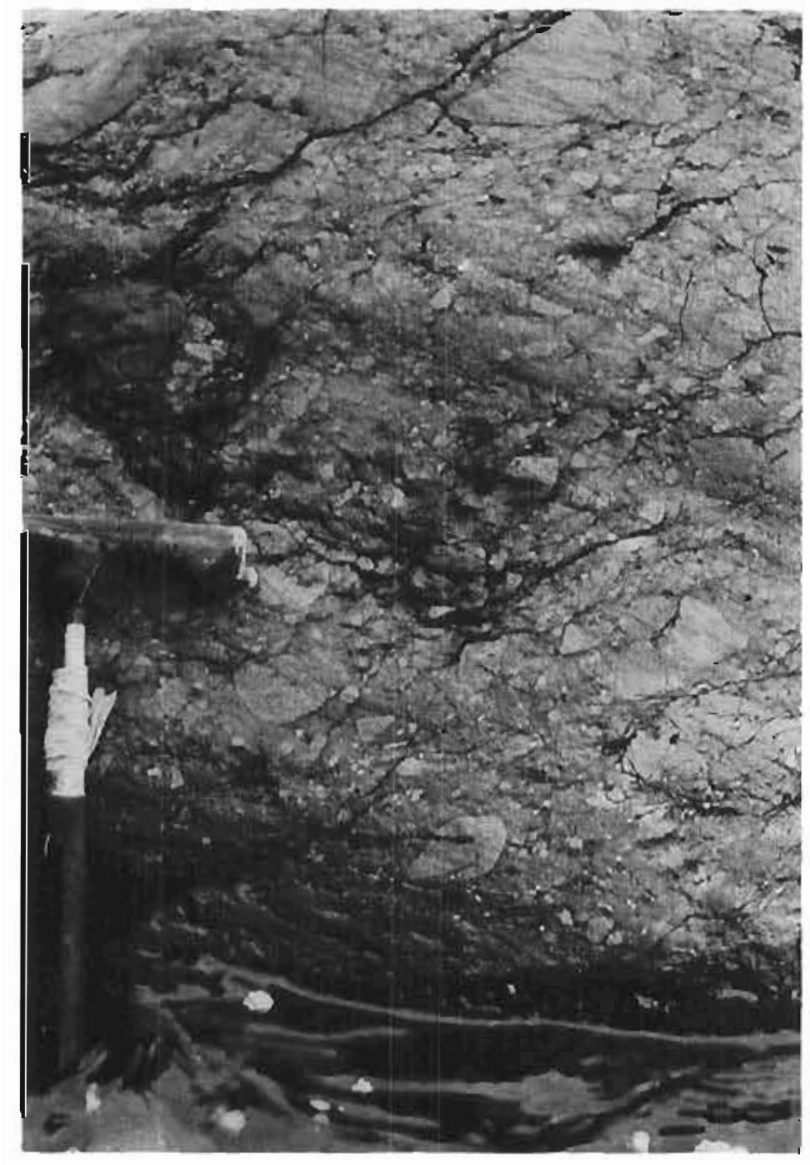

Figure 12. Descon Formation sheared conglomerate of the Odsg unit with red argillite and graywacke pebbles in a sheared argillaceous matrix. West shore of Klakas Inlet, $2.5 \mathrm{~km}$ from its head. 
stone beds as thin as $1 \mathrm{~cm}$ grade from coarse at the base to line at the top. They have sharp bottom contacts that are irregular in places because of the scouring or. the underlying argillite. Contacts of siltstone beds with the overlying argillite beds may be sharp or gradational, planar or interfingering. Wisps of argillite are found in the siltstone. By use of these features, the tops of beds can usually be determined. Minor folds and crenulations are not found. Except for a large area of slaty cleavage and quartz veining east ol Klakas Lake, cleavage was generally alssent.

Gray wacke beds from 1 to $3 \mathrm{~m}$ thick are common in the Odm unil. On the north shore of the bay west of Klakas Lake, a 1-m-thick graywacke bed interbedded with mudstone contains intraformational clasts of thinbedded mudstone foating in the central porlion (ng. 13). The graywacke and intraformational clasts were likely emplaced simultaneously as a turbld mudflow. The thin, graded mudstone beds were probably deposited at the outer margins of turbid mudnows. The argillite beds hal are not the graded tops of mudstone beds probably originated as abyssal mud.

Limy rocks are nearly lacking, but two beds of slagweathered, limy matrix conglomerate simllar to those in the underlying Odsg unit are present near the base of the unit. These support the interpretation that the Odsg and Odm units are conformable, despite the presence of shearing along the contacl.

\section{GRAYWACKE (Odg)}

Gray wacke beds are massive, greenish gray, 1 to $5 \mathrm{~m}$ thick, and range in size from silt to sand. Individual beds are not banded and do not vary in grain size. Pebbles and occasionaly larger clasts of chert or banded mudstone noating in the central portions of beds indicate an origin as submatine mud flows or lurbidity currents. Commonly, thin-banded mudstone layers less than 30 $\mathrm{cm}$ thick are interbedded with the gray wacke at stratigraphic intervals of 3 to $30 \mathrm{~m}$. These mudstones are identical with those Pound in the Odm unil.

Albite gralns are visible in some outcrops and a thin section of conglomeratlc gray wacke on the west shore of KJakas Inlet, $40 \mathrm{~km}$ from its head, reveals closely packed subangular clasts of metakeratophyre(?) (quartz-albite metafelsite containing albite phenocrysts). A similar outcrop, although chloritized, is present on the ridge $3 \mathrm{~km}$ southwest of the extreme head of the iniet. The presence of metakeratophyre(?) as clasts in the Odg unit suggests that source rock of at least part of the Descon Formation is the Wales Group.

\section{ARGILLITE (Oda)}

Near the top of the banded mudstone-graywacke sequence $(0 \mathrm{dm})$ on the east shore of Klakas Inlet are two sections of argillite (Oda) up to $100 \mathrm{~m}$ thick (or one section, repeated by (aulting). The unit is dark gray, with thin ballds of a very dark gray slate and a few limestone concretions up to $1 \mathrm{~m}$ in diameter.

\section{BASALT (Odb)}

Mafic volcanic rocks at the lop of the Descon(?) Formation section on Klakas Inlet are at least $1,200 \mathrm{~m}$ thick. The rocks are greenish gray and form steep, rocky shorelines. Most of the rock unil (Odb) is massive, joinled, and lacks pillow structure. (Locally isolated pillows in fragmental rocks or angular blocks. occur in a flow-rock inatrix.) A lypical oulcrop has angular 2. to $10 \mathrm{~cm}-\mathrm{cong}$ fragments of limy, light. greenish-gray aphanitic basall that stand oul on weath. ered surfaces above the background of the same rock. In thin section the rock is seell to have an interstitial texture. There are dusly-albitized(?) plagioclase laths $(0.2 \mathrm{~mm}$ long) in a dark matrix of devitrified glass that contains chlorite and epidote and amygdules of calcile and quatiz epidole. Thin sections with plagioclase fresh enough for the determination of composition show albite-rich basalt or spilite, which indicates al. bilization of more calcium-rich plngioclase.

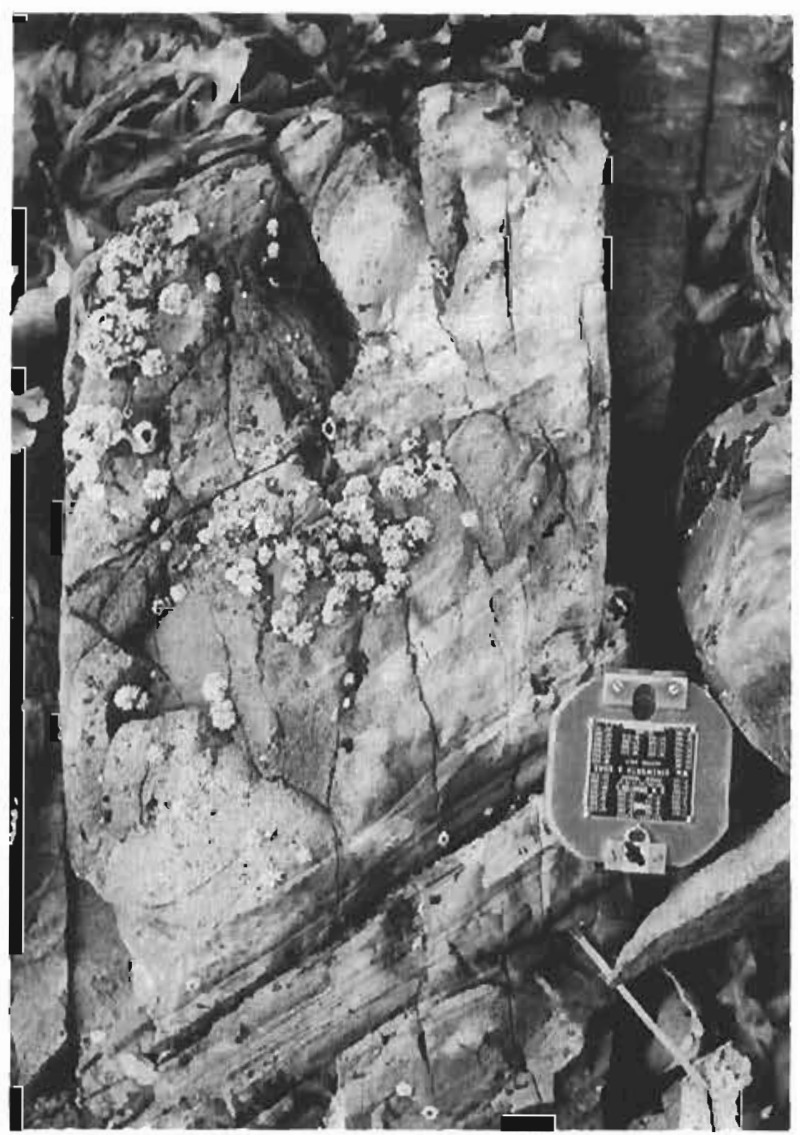

Figure 13, Descon Formation banded mudstone and graywacke with loaling mudstone fragment (parl of Odm unit), easl shore of Klakas iniet near outlet from Klakas Lake. 
Two chemical analyses (table 2, Nos. 6, 12) and alkali-silica diagram (p. 28) slow the alkaline nature of these Descon basalts.

\section{AGE OF THE DESCON RORMATION}

'The age of the Descon Formation has been estab. lished as Middle Ordovician to Silurian on the basis of fossil collections made on the west side of Sukkwan Island (Eberlein, pers. comm.). More recent graptalice collections made on Klakas Ynlet (Eberlein. pers. comm.) generally confirm the assignment of the rock units to the Descon Formation. Although the volcanic and sedimentary units on South Arm (Ods and Odv) could be part of the Wales Group, they are assigned to the Descon Formation.

\section{SILURIAN(?) IGNEOUS ROCKS}

\section{ALTERED GRANODIORITE (Sgd)}

Saussuritized granodiorite and alaskite are present along the northern edge of Max Cove. This is probably the southwest edge of a large pluton that forms the mountain northeast of Max Cove, which corresponds with the location of a prominenl aeromagnetic high (Rossman and others, 1956). The rock is an albitized gramodiorite breccia wilh fragments cemented by alaskite.

In thin section some of tlye dark breccia blocks are seen to be made up of saussuritized feldspar and fresih poikilitic hornblende with ragged borders. In coorser grained rock the dark breccla fragments are albitized granodiorite. There are fresh, euhedral, green hormblende crystals, tabular crystals of saussuritized albite with albite twinning, and irregular grains of potassium feldspar and quartz. The alteration of the plagloclase feldspar was probably deuteric. A chemical analysis of a sunple (table 2, No, 16) from this plutun shows it to have calc-alkaline affinities, as do Paleozolc intrusive rocks at Bokan Mountain (Mackevett, 1957).

Potassium-argon dating reported by T'urner and others (1977) of hornblende ill deuterically altered granodiorite on the north shore of Max Cove gives a minimum age of $421 \mathrm{~m} . y$. (Inid-Silurian or older). This rock type may be part of the same sulte of intrusives as the quarte diorite and quartz monzonite complexes near Bokan Mounlain, $15 \mathrm{~km}$ to the east, which liave potassiumargon ages of $432 \pm 13$ and $410 \pm 13 \mathrm{~m} . \mathrm{y}$., respectively (Lanphere and others, 1964).

\section{ALASKITE (Sa)}

Alaskite, which has a distinctive micrographic texture, forms a long, eliptical plutonic body on both sides of Klakas Inlet, where it intrudes(?) into the Descon Formation. The alaskite is medium grained and commonly weathers to a pale yellow. In many outcrops the rock is crackled into 2- to 8-cm-wide blocks that are cemented by thin dolomite-sericite-magnetite seams (fig. 14). Feldspar phenocrysts are visible in some localities. There are no malic minerals. In thin section the rock is mainly subhedral grains of perthite and albite, with some quart\%. The Peldspars have been extensively sericitized and their margins are embayed by quartz. In their central portions partial replacement by quartz formed lacy micrographic intergrowths of quartz albite and quartz perthite. The rock has been cut by younger dolomite-sericite-magnelite-chlorite veinlets. The alaskite contains about 30 percent perthite.

The alaskites on both sides of Klakas Inlet appear similar, and are probably related to a cominon pluton. The micrograpilic intergrowths are similar and both areas are cut by carbonate-sericite-magnetite-leucoxene veinlets.

The age of the alaskite is believed to be the same as the dated granodiorite (Sgd) described above. Alaskite is found as a cement in a gramodiorite (Sgd) breccia al Mrax Cove.

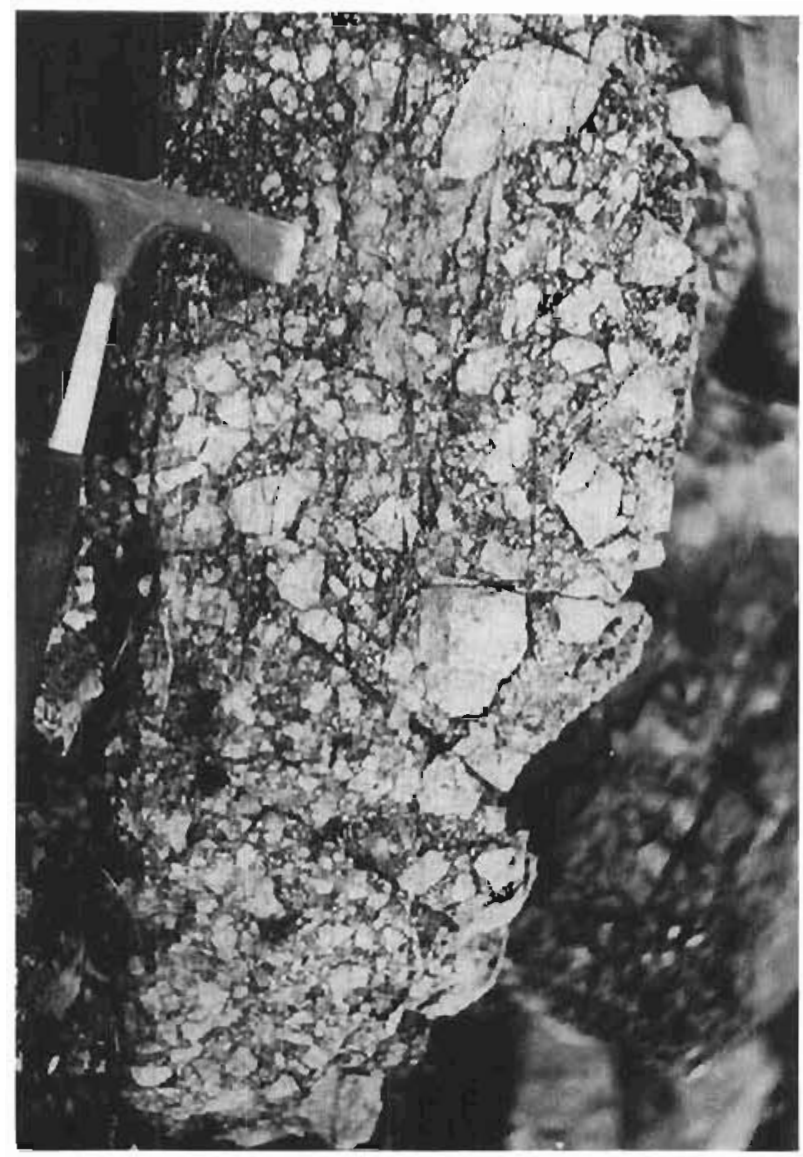

Figure 14. Silurian crackled alaskite cemented by dolomite. Boulder on eastern shore of Klakas Inlet, neak Max Cove. 


\section{KERATOPHYRE(?) (Sk)}

Sills and dikes of keratophyre(?) cut Descon Formation rocks on Klakas Inlet. The rock is ligh t-gray felsite that weathers to coarse, grayish-orange rubble in beach exposures. Some bodies are aphanitic near the central portions and contain visible feldspar laths near the contacts with the country rock.

In thin section the rock displays euhedral twinned albite laths up to $2 \mathrm{~mm}$ in a fine-grained granoblastic matrlx composed mostly of equant albite and quartz grains with minor sericite. Twinned plagioclase microlites are not as common as in the groundmasses of Wales Group metakeratophyre on Hetta Inlet, but otherwise the rocks are similar. No chemical analyses of this rock type are available, and assignment as keratophyre is based on mineralogy.

The keratophyre(?) sills posidate the Middle Ordo. vician and are probably Silurian. They cut the Descon Formation on Klakas Inlet and are peripheral to Silurian plutons. However, they also could be related to the Cretaceous plutons in the area.

\section{DEVONIAN BEDDED ROCK UNITS}

\section{INTRODUCTION}

Devonian bedded rocks are represented by a $2,000-\mathrm{m}-$ thick section of unfoliated dark-gray argillites and siltstones, greenish- to medium-gray siltstones and graywacke, and conglomerate. There is a 'basal' conglomerate near the base of the section. Andesitic volcaric rocks capping the sediments could be younger than the Devonian. Figure 15 is an approximate section of the Devonian rocks between Klakas and Keete Inlets.

\section{BASAL CONGLOMERATE AND RED BEDS (Dbc, Dar)}

Devonian rocks are separated from the underlying Descon Formation by a transgressive unconformity. The contact is marked by an unsheared basal conglomerate containing clasts derived locally from the underlying rocks. Progressing northward the most abundant clasts change from granodiorlte to dark-gray argillite to grayish-red argillite.

The basal conglomerate (Dbc) is costsest on the north shore of Max Cove, where 14 contains cobbles, gravels, and boulder conglomerate witl granodiorite clasts up to $3 \mathrm{~m}$ across. These clasts are similar to the nearby dated pluton that intrudes the Descon Formation. Other clasts include basalt, felsite, red argillite, and black slate. The gravels interfinger with overlying fossiliperous limestone.

On the west shore of Klakas Inlet, the Devonian basal conglomerate (Dbc) overlies alaskite (Sa) and contains fragments of that rock up to $12 \mathrm{~cm}$ ucross in a gray. wacke matrix.

North of the alaskite ( $\mathrm{Sa}$ ) pluton the Devonian basal conglomerate beds are less coarse grained and contain no granitoid clasts. The basal rocks (Dar) are typically medium reddish-gray graywacke or siltstone and distinctive purple to grayish-red argillite, with scattered angular to subangular 1 - to $5 \mathrm{~cm}$ clasts of white-weathering, dark-gray argillite and greenish-gray siltstone. At the north limit of the basal conglomerate beds, in the Keete Inlet drainage, the graylsh-red beds (Dar) and pebbles in gray wacke derived from the Descon Formation are common.

Some of the beds in the lower part of the Devonian section-particularly the graywacke, mudstone, and red argillite beds are identical in composition and texture to rocks in the Descon Formation below the unconformity and could be tectonic slices of the Descon Pormation.

ARGILLITE-SILTSTONE (Da), SILTSTONEGRAYWACKE (Dsg), PEBBLE-CONGLOMERATE (DPc), LIMESTONE (DI), AND FELSITE PEBBLE CONGLOMERATE (Dkpc)

Above the basal conglomerate the Devonian bedded rocks, for the most part, become finer grained and consist mainly of argillite, siltstone, limestone, and minor pebble conglomerale (fig. 15). This 1,800 -m-thick sec. tion is capped by andesite breccias, lows, and volcaniclastic rocks.

The predominant rock type is a heterogeneous unil of dark-gray siltstone and dark-gray argillite (Da) (fig. 16). Directly above the basal conglomerate (Dbc), the Da unit consists of about $600 \mathrm{~m}$ of dark-gray sillstones and subordinate dark-gray argillite. Within the lower $100 \mathrm{~m}$ of this $\mathrm{Da}$ section are subordinate but distinctive dolomitic concretions, usually 0.1 to $3 \mathrm{~m}$ thick and a few meters long (fig. 15). The concretions are fainuly banded and usually parallel the siltstone beds. Some banding in the concretions is oriented slightly oblique to the sedimentary layering within the $\mathrm{Da}$ unit. These dolomitic concretions may represent open space lillings with bands being successive water levels during filling. Some evidently filled while the beds were horizontal, others during tilting. In the upper $1,200 \mathrm{~m}$ of the Devonian-sedimentary section the $\mathrm{Da}$ unit becomes finer grained and consists of dark-gray argillite and sub. ordinate siltstone.

Within the Da unit are subordinate but mappable beds of intraformational pebble conglomerate (Dpc), siltstone and graywacke (Dsg), and locally lossiliferous (e.g. Max Cove) limestone (DI). These subordinate units are generally less than $20 \mathrm{~m}$ thick and lense out along strike. Pebbles in the Dpc unit consist of argillite, siltstone, and graywacke, some possibly derived from the underlying basal conglomerate (Dbc) unil. $\Lambda$ typical exposure of the Dsg unit contains a series of $15-\mathrm{cm}$-thick greenish.gray beds that grade from graywacke at the base to siltstone at the top and are separated by $1 . \mathrm{cm}$ partings of argillite. Limestone (DI) al Max Cove is light gray, essentially nonbanded, and very finely re. 
Meters

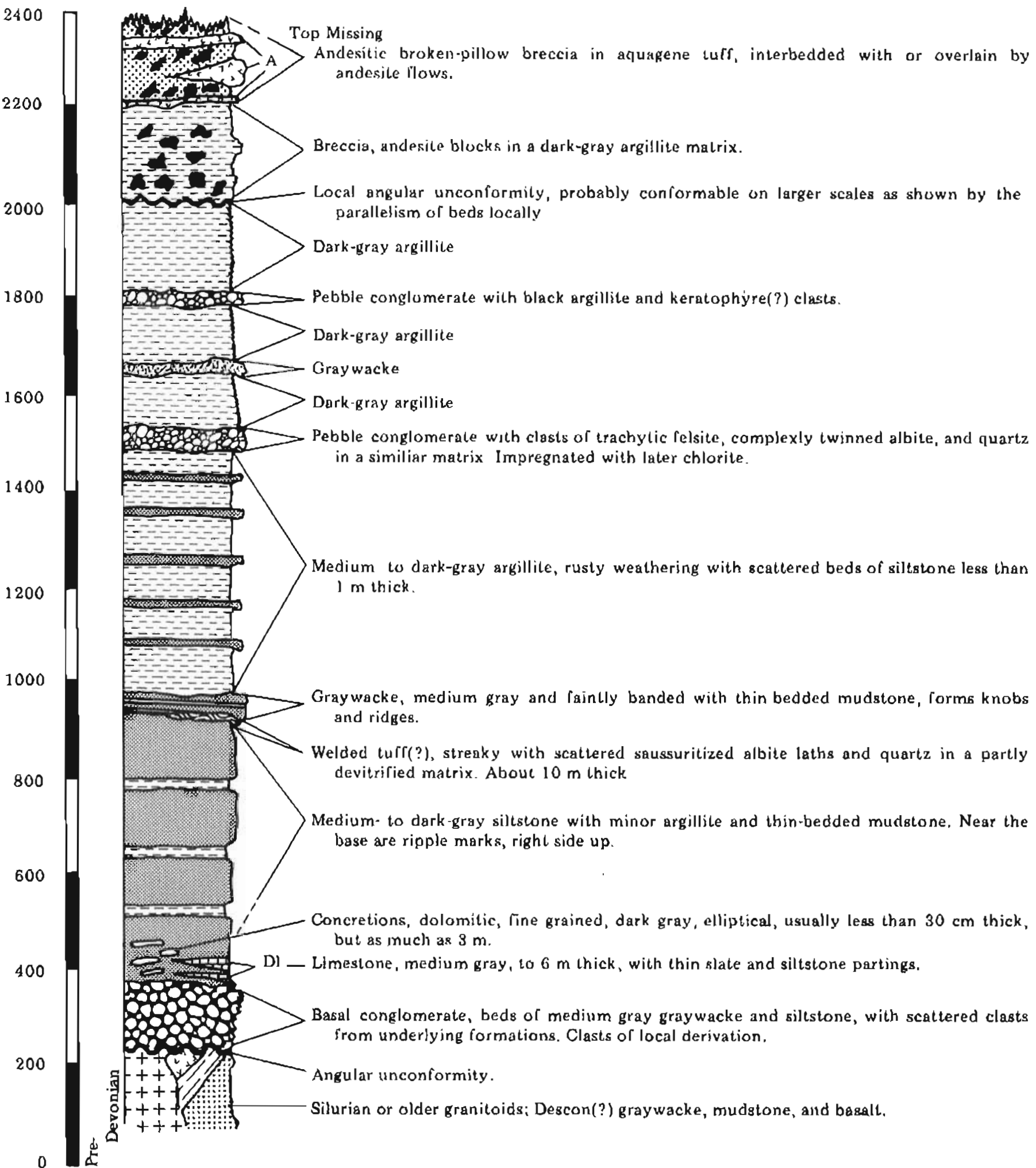

Figure 15. Devonian stratigraphic section between Klakus and Keete Inlets (thicknesses are approximate). 
crystallized and contains small dolomitic inclusions.

In the upper part of the Devonian sedimentary seclion (fig. 15), the Da unit is interbedded with 10. to 30-m-thick beds of greenish-gray clastic rocks (Dkpc) derived from a lelsite(?) that consists of twinned plagio. clase and quarti grains. Interbedded wilh the conglomerates are subordinate greenish-gray argillite and siltstone.

\section{AGE}

Clurkin and others (1970) have identified graplolites in the Da unit that are latest Lower Devonian or earljest Middle Devonian. They found fossils al four locallies in Klakas and Kassa Inlets in black slate. apperently in the upper beds of the dark-gray argilite unit. The diagnostic Cossil is a graptolite Mongraplus pacificus, of 'Praguian' or possibly a slightly younger horizon that extends into the Middle Devonian.

A coral reef located in the $\mathrm{Dl}$ unit above the unconformity at the base of the Devonian section on the north shore of Max Cove (pl. 1) was first reported by Budding. ton and Chapin (1929). According to Churkin and others (1970), it is "limestone rich with tabulate corals and stromatoporoids...apparently long-ranging species that cannot be assigned to any specific part of the Devonian."

\section{ANDESITE(?) (Dand)}

Devonian(?) andesite forms an outcrop band of sub. marine andesitic tu[f, flows, and sedimentary breccia that extends from Keete Inlet south to the edge of the map area, east of Kassa Inlel. On Kassa Inlet this unit crops out as shoreline cliffs of distinctive unfoliated greenish-gray, blocky. locally amygdaloidal, aphanilic andesile flows and tuff. In the flows, calcite stringers that cut the rock weather to give the surface a blocky crackled appearance with blocks about $3 \mathrm{~cm}$ in diameter. The llows in thin section sloow devitrified glass with diffuse carbonate patches and liny magnetite grains. Eise where the rock is a slightly foliated, aphanitic tuff with 6-cm-long andesitic fragments. Pillows were not recognized on Kassa Iniet. Northeast of the head of Kassa Inlet the andesite is amygdaloidal welded(?) tuff with a streaky appearance in outcrop and contains shard-shaped chlorite masses. In upland areas east of the head of Kassa Inlet the rock is mainly conglomerate, made up of rounded to angular andesitic clasts $1030 \mathrm{~cm}$ long in a matrix of black slate and thin-bedded silt. stone pebbles.

Along the south shore of Keete Inlet, nearest the thrust fault (pl. 1), the unit is believed to be a hyaloclastite broken pillow breccia (Carlysie, 1963). It has irregular, rounded andesite pillows with chilled borders in a matrix of darler, grit-sized porphyry fragments. This is cut by similar andesile dikes with chilled borders. Nearby, there is andesite composed of angular $1 \cdot \mathrm{cm}$ fragments. Fartler east, the rock is a sedimentary breccin made up of angular andesite and thin-banded mudstone blocks in a dark.gray argillite inatrix. This sequence of tuff on the west and the sedimentary breccia on the east al Kassa and Keete Inlets may not hold true for the mass of the unit in between.

The Devonian(?) andesite (Dand) unit generally parallels and is roughly conformable with the underlying Devonian argillice (Da) unit, but local uncon. formilies do exist between the two units. Devonian("?) andesite (Dand) is the youngest bedded deposil in the map area. It is tentatively considered to be Devonian on the basis of regional correlation with the Devonian St. Joseph volcanic rocks on the west coast of Prince of Wales Lsland (Eberlein and Churkin, 1970).

\section{PALEOZOIC(?) DIKES (Pdk)}

\section{INTRODUCTION}

Dikes in the study area vary in composition, texture, age, and orientation. They are andesitic and basaltic, line-grained and diabasic and intride along joint sets,

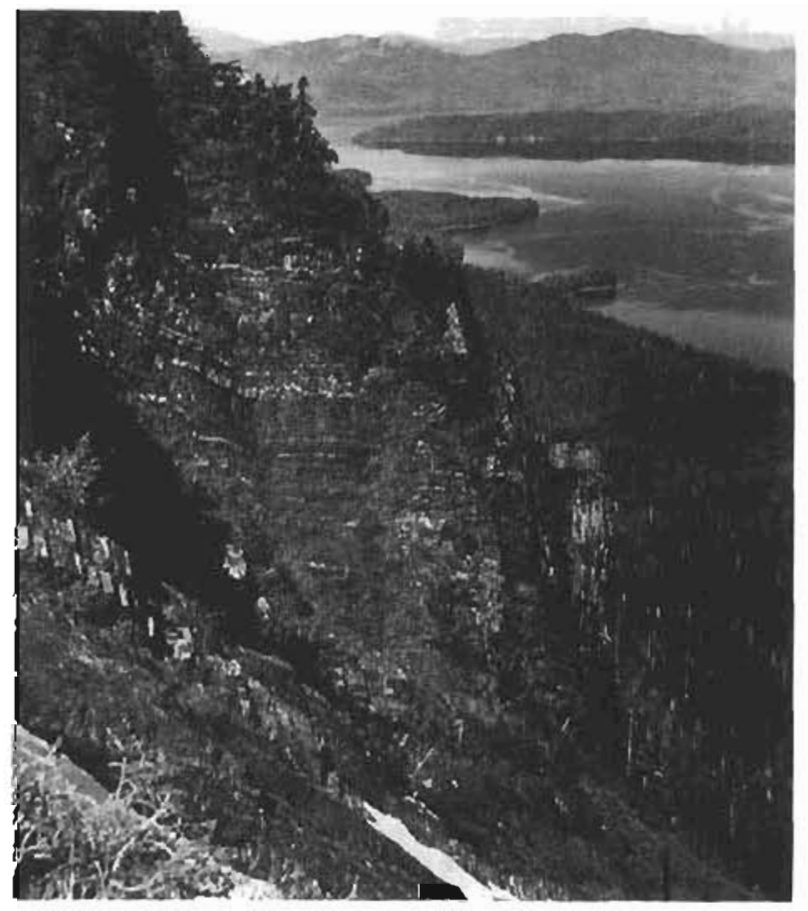

Figure 16. Devonian argillite and siltstone (Da), Kcele and Nulkwa lnlels in background. 
There are a few felsic dikes related to nearby plutonic bodies. Compositions categorized in this section are based on hand-specimen and thin-section examination. Because of their small size, most dikes are not shown on plate 1.

\section{FELSITE DIKES}

Several quartz-albite-felsite dikes in the Klakas Inlet area near Max Cove are probably related to the nearby earty Paleozoic(?) granodiorite pluton (Sgd) on Max Cove.

\section{AMYGDALOIDAL PORPHYRITIC BASALTIC ANDESITE DIKES}

Dikes of basaltic andesite along Hetta Inlet and Sukkwan Strait cut both the Wajes Group and the Descon Formation rock units. They have chilled borders, are conspiciously greenish black, and are made up of fine-grained, randomly oriented, rather sericitized andesine-to-labrodorite laths with intersitial clinopyroxene, basaltic hornblende, and magnetite grains. Pyroxene and plagioclase phenocrysts are $2 \mathrm{~mm}$ long. Olivine is locally psuedomorphosed by patches of carbonate, chlorite, and opaques. Many dikes, but not als, contain amygdules of carbonate fringed with chlorite. Lamprophyre(?) inclusions were observed in one dike.

\section{PORPHYRITIC DIABASE DIKES}

Diabase dikes are the most common type in the map area. Their textures range from that of coarse-gxained basalt or andesite to diabase and often have chilled borders, and their composition ranges from basic ande. site to basalt. Groundmass plagioclase laths are albite twinned. The albites range in length from 0.7 to $2.0 \mathrm{~mm}$ and vary from An-40 to An-60. Between the plagioclase laths are smalter grains of fresh pyroxene and magnetite(?) with patches of chlorite and carbonate. Chlo. rite makes up 5 to 20 percent of the rock. Some rocks have a trace of brown biotite in the groundmass.

Porphyritic basaltic diabase follows a fault with a meter or so of left lateral offset at Copper City (p.42). This dike is $4 \mathrm{~m}$ wide, vertical, and strlkes $\mathrm{N} .35^{\circ} \mathrm{W}$. It has chilled borders and contains rounded clusters of mafic minerals up to $2 \mathrm{~mm}$ in diameter. In thin section the rounded clusters are composed of serpentine and iron opaques, pseudomorphic after olivine, in a diabasic matrix. The diabasic matrix is made up of slim, divergent, albite-twinned labradorite Iaths (An.60) up to $2 \mathrm{~mm}$ long with interstitial grains of fresh clinopyroxene, iron opaques, patches of chlorite, and brown horn. blende.

Porphyritic diabase of andesitic composition cuts Wales Group metakeratophyre tuff on the east shore of Nutkwa Inlet. This dike is similar to the diabase described above, except that the plagioclase is An.45, brown biolite replaces brown bornblende, and the plagioclase laths are shorter (up to $1 \mathrm{~mm}$ long). There are phenocrysts of sericitized plagioclase up to $5 \mathrm{~mm}$ long, fresh clinopyroxene(?), and serpentine-jron opaques pseudomorphic after olivine.

\section{AMYGDALOIDAL PORPHYRITIC ANDESITE DIKES}

These dikes and small sills are up to $3 \mathrm{~m}$ thick and have chilled borders. A typical example is a sill on the west coast of Nutkwa Inlet, which is made up of tinegrained, randomly oriented, much sericitized and leucoxenized albite-twinned andesine laths separated by patches of chlorite, carbonate, and leucoxene. Phenocrysts are sericitized and leucoxenized plagioclase up to $5 \mathrm{~mm}$ long. Amygdules are calcite rimmed by chlorite. These al tered rocks contain no pyroxene.

\section{THERMALLY METAMORPHOSED DIKES}

Thermally metamorphosed dikes of variable composition are common in the hornfels aureole around Copper Mountain and on the north shore of West Arm. Some of these dikes, because of their large euhedral homblende phenocrysts in a saccharoidal plagioclase and hornblende matrix, have the appearance of lamprophyre dikes. A thin sectlon from a I-m-thick dike on the west end of Gould Island shows it to be a partly. recrystallized porphyry dike with late poikilitic hornblende and altered relict plagioclase phenocrysts. This groundmass is made up of irregular-shaped hornblende and zoned plagioclase microlites (cores, An-45; rims, An-30). Zoving is believed to be the result of partial decalcilication during contact metamorphism.

A typical andesite dike that has been thermally metamorphosed in the hornfels zone southwest of Gould Island has zoned feldspar microlites with blurred margins probably due to extensive recrystallization. The feldspar cores are An-55 and the rims are An-40. Chlorlte grains are larger and more distinctive than other less thermally metamorphosed dikes. Another dike nearer the intrusive shows chlorite replaced by diopside. The plagioclase grains (An-45) retain albite twinning but their margins are blurred because of recrystallization.

\section{STRUCTURE}

None of the Paleozoic(?) dikes are foliated and most that intrude the Wales Group have chilled borders with the enclosing schist. Most dikes are steeply dipping and have two preferred orientations across the map area. The most frequent width of dikes is $0.6 \mathrm{~m}$ on Hetta Inlet and $0.3 \mathrm{~m}$ on Chomondeley Sound (fig. 17). There are from 10 to 50 dikes per $\mathrm{km}^{2}$ along Hetta Inlet north of Hetta Point (versus 5 to 15 per $\mathrm{km}^{2}$ throughout the rest of the map area).

Most of the dikes dip more than $70^{\circ}$. The steepness and two-directional orientation of dikes is illustrated in 


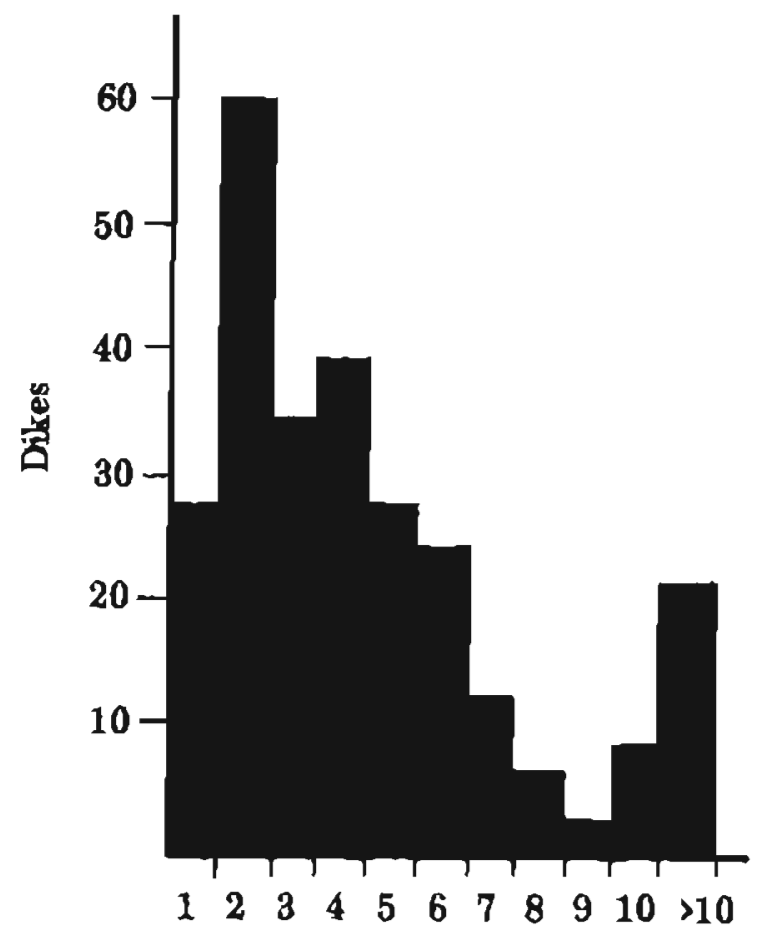

Width (ft.)

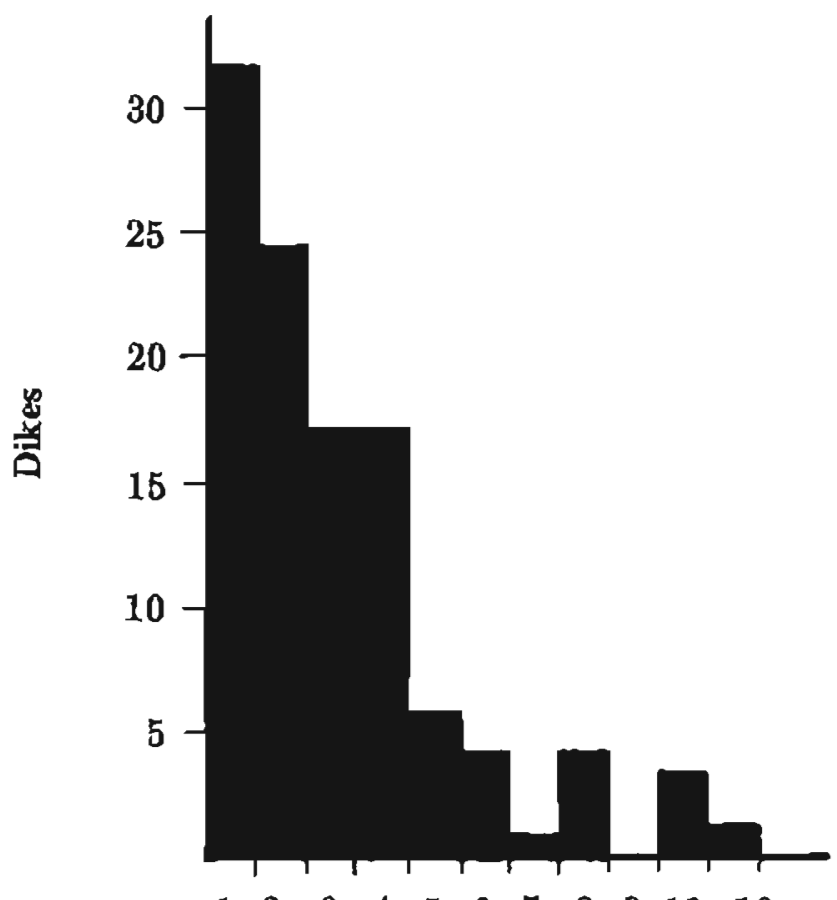

$\begin{array}{lllllllllll}1 & 2 & 3 & 4 & 5 & 6 & 7 & 8 & 9 & 10 & 10\end{array}$

\section{Width (ft.)}

Figure 17. Dike measurements in Hetta Inlet and Cholmondeley Sound. Paleozoic(?) mafic dikes intrude the Wales Group, Descon Formation, and Devonian sedimentary and volcanic rock units, Left. Hetta Inlet dikes (246 measurements). Right - West and South Arms, Cholmondeley Sound (108 measurements).

figures 18 and 19 , which record 400 dike orientations in the map area. The most frequent dike direction along Hetta Inlet, N. $60^{\circ} \mathrm{W}$, is at roughly a $120^{\circ}$ angle to the most frequent dike direction along the South and West Arms of Cholmondeley Sound, which is N. $60^{\circ}$ E. A similar conjugate system of mafic dikes is present at McLean Arm, $50 \mathrm{~km}$ to the southeast (Forgeron and LeRoy, 1971).

\section{AGE}

Andesite and basalt dikes of a conjugate system intrude the Wales Group and Descon Formation throughout the map area as well as the Middle Devonian rocks on Klakas and Kassa Inlets, but do not clearly cut Cretaceous igneous bodies. Some of these dikes may be related to volcanism found in the various rock sequences. Leavens (1967) believes the altered mafic dikes within the Copper Mountain skarn zone are related to epidote mineralization; if this is true, some mafic dikes could be of Cretaceous age. A few keratophyre(?) and felsite dikes related to the Silurian plutons on Klakas Inlet are probably of Silurian age.

\section{CRETACEOUS INTRUSIVE ROCKS}

\section{ALTERED PORPHYRITIC DIORITE (Kdip)}

Small plutonic bodies averaging $2 \mathrm{~km}^{2}$ of altered porphyritlc diorite intrude the Wales Group, the Descon Formation, and Lower Devonian rock sections in the south-central part of the map area (pl. 1). Thin sections from nine different bodies showed mineralogical compositions ranging from syenite to diorite. Textures are prophyritic to seriate with plagioclase phenocrysts ranging up to $5 \mathrm{~mm}$ long. Plagioclase phenocrysts are twinned, unzoned, and lath shaped, and have been altered to albite. All bodies contain pyroxene, often partly altered to chlorite, and some contain biotite; none have hormblende. Perthite content ranges from 0 to about 55 percent. Accessories are sphene, leucoxene, ilmenite, and apatite. Alteration by saussuritization of originally calcic-plagioclase produced albile, epidote, and sericite. Partial chloritization of the pyroxene and biotite has also taken place.

A Kdip pluton that incrudes the Wales Group on the south side of Keete Inlet is composed mainly of lacy intergrowths of guartz and albite without mafic minerals and courd be called an alaskite. The rock is cut by chlorite, sericite, magnetite, and carbonate veinlets. The Kdip pluton at the east side of Keete Inlet in- 


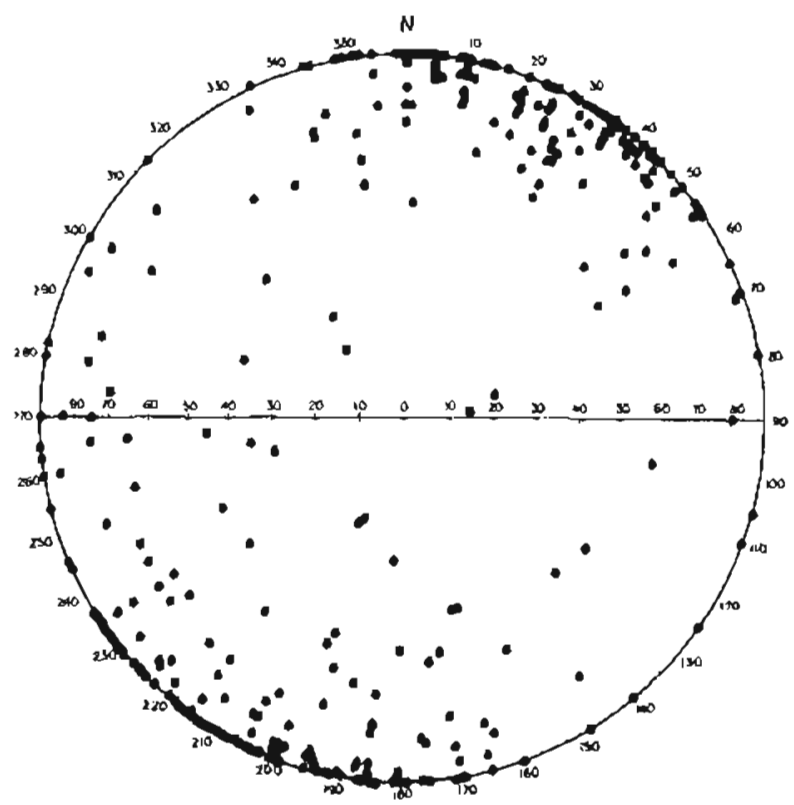

Figure 18. Attitudes of 292 dikes along shoreline of Hetta Inlel north of Hetla Cove.

trudes into Devonlan sediments. Here it is slightly crackled and made up of medium-grained perthite with small amounts of interstitial fine-grained quartz, carbonate, and chlorite veinlets.

\section{GRANODIORITE (Kgdi)}

The Copper Mountain pluton is a heterogeneous intrusive body with many roof pendants and satellite bodies and is surrounded by a wide-contact metamorphic aureole. The mineral deposits and crystal localities that have made the district famous are in this aureole, particularly where the pluton intrudes Wales Group calcareous rocks.

The central part of the Copper Mountain pluton is mostly granodiorite, whereas its margins and other granodiorite plutons are varied. Kennedy (1953) noted compositional changes from syenite to gabbro over a few hundred meters within the border phase of the Copper Mountain intrusive. Locally, dark early Intrusive rock is cut by lighter colored intrusive rock. At other localities epidote veins and other skarn minerals replace the igneous rock.

A marginal mixed zone of inclusion-charged hornblende gabbro separates the Gould Island and Copper Mountain plutons along the narrow channel south of Gould Island. The inclusions are angular to rounded epidotized gasbro, amphibolite, and fine-grained mafic rock. Near the contact are patches of coarse-grained metasomatic(?) amphibolite with hornblende crystals up to $15 \mathrm{~cm}$ long (fig. 20). The rock is cut by inclusionfree granodiorite dikes that are probably the same age as the central Copper Mountain intrusive. In some places

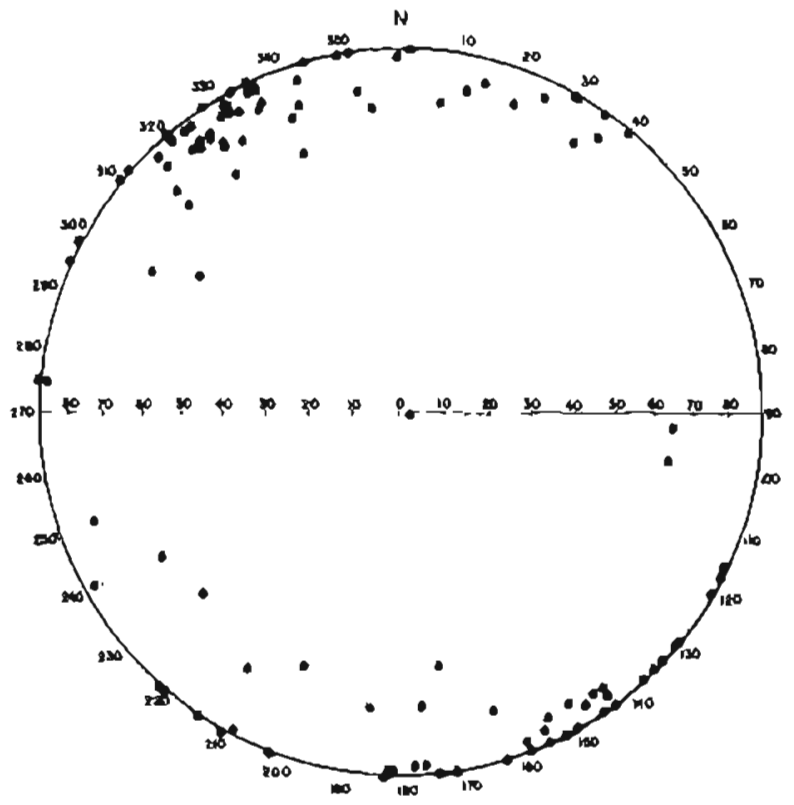

Figure 19. Attitudes of 108 dikes along South and West Arms, Cholmondeley Sound.

these septa are gabbro breccla cemented by granodiorite.

farther east, on the south shore of Portage Bay, the marginal zone is composed of faulted skarn, marble, gabbro, and hornfels cut by inclusion-free granodiorite dikes and aplite veins. These contact areas show the vigorous nature of emplacement of the plutons. On the ridge north of Copper Harbor, the granodionite is partly transformed to skam along its west conlact (pl. 1 and p. 37.38).

The Copper Mounlain pluton is mainly granodiorite with some mon\%onite, quartz monzonile, and diorite (lable 1). It has large poikilitic polassium feldspars with abundant inclusions of plagioclase and mafic minerals. In thin section, plagioclase is subhedral and normally zoned with cores ranging from An-20 to An-40 (rims were not determined). Mafic minerais are strongly pleochroic green to straw-yellow homblende, slightly greenish pyroxene, and minor amounts of browis biotite. The granodiorite usually contains 0.3 to 2.0 percent magnetite. Apatite is an abundant accessory. The large anhedral potassium feldspars are up to $5 \mathrm{~mm}$ in diameter and were the last mineral to crystallize in the magma, perhaps before intrusion into the present crustal level. Potassium feldspar veinlets also cul the rock, indicating postcrystallization potassium enrichment. Chemical an. alyses of the two Copper Mountain pluton samples show quartz monzonite and diorite composition (table 2, Nos. 18, 19).

\section{EPIDOTIZED GABBRO AND DIORITE (Keg)}

Epidotized gabbro and diorite make up the small $\left(3 \mathrm{~km}^{2}\right)$ pluton on the north side of Green Monster 
Table 1. Modes of selected granodiorite and related rocks (Kgdi) (bosed on Jooo points counted per stained siab)-in percent. ${ }^{I}$

\begin{tabular}{|c|c|c|c|c|c|c|c|c|c|c|}
\hline Type ${ }^{2}$ & Unit & Sample & Quartz & Plagioclase & $\begin{array}{c}\mathrm{K} \\
\text { feldspar }\end{array}$ & $\begin{array}{l}\text { Mafic } \\
\text { minerals }\end{array}$ & $\begin{array}{l}\text { Accessory } \\
\text { minerals }\end{array}$ & Alteration & Location & Remarks \\
\hline Granodiorite & $\begin{array}{l}\text { Hetta Lake } \\
\text { pluton }\end{array}$ & $70 \mathrm{C} 110$ & 21 & $\begin{array}{l}57 \text { normal zoning, } \\
A n^{2} 40\end{array}$ & 7 & $\begin{array}{l}14 \text { biotite } \\
\& \text { horn- } \\
\text { blende }\end{array}$ & $\begin{array}{l}1.1 \text { magnetite } \\
\text { apatite sphene }\end{array}$ & Fresh & $\begin{array}{l}\text { West end } \\
\text { Hetta Lake }\end{array}$ & $\begin{array}{l}\text { More biotite than } \\
\text { average. K-Ar aver- } \\
\text { age age-hbde. } 103 \\
\text { m.y., biotite } 105 \mathrm{~m} . \mathrm{y} \text {. }\end{array}$ \\
\hline Granodiorite & $\begin{array}{l}\text { Copper } \\
\text { Mtn. plu- } \\
\text { ton }\end{array}$ & 700194 & 18 & 48 zoned, An-35 & $\begin{array}{l}18 \text { poi- } \\
\text { kilitic } \\
\text { perthite }\end{array}$ & $\begin{array}{l}14 \text { horn- } \\
\text { blende }\end{array}$ & $\begin{array}{l}1.2 \text { magnetite } \\
\text { apatite sphene }\end{array}$ & $\begin{array}{l}\text { Plagioclase } \\
\text { flecked by } \\
\text { sericite }\end{array}$ & $\begin{array}{l}\text { Summit } \\
\text { Lake, } \\
\text { south side, } \\
\text { near out- } \\
\text { let }\end{array}$ & Honey-yellow apatite. \\
\hline Granodiorite & $\begin{array}{l}\text { Copper } \\
\text { Mtn. pla- } \\
\text { ton }\end{array}$ & $70 \mathrm{C} 197$ & 17 & $\begin{array}{l}56 \text { zoned }(2 \mathrm{~mm}) \\
\text { An } 40\end{array}$ & $\begin{array}{l}10 \text { poi- } \\
\text { kilitic } \\
\text { large }\end{array}$ & $\begin{array}{l}15 \text { horn: } \\
\text { blende \& } \\
\text { bjotite }\end{array}$ & $\begin{array}{l}1.3 \text { magnetite } \\
\text { apatite sphene } \\
\text { fluorite(?) }\end{array}$ & Fresh & $\begin{array}{l}\text { Summit } \\
\text { Lake, } \\
\text { south side, } \\
1.4 \mathrm{~km} \\
\text { from out- } \\
\text { let }\end{array}$ & \\
\hline $\begin{array}{l}\text { Quarlz dio- } \\
\text { rite }\end{array}$ & $\begin{array}{l}\text { Copper } \\
\text { Mtn. plu- } \\
\text { ton }\end{array}$ & 700198 & 17 & $50, A_{n} \cdot 25$ & $\begin{array}{l}2.3 \text { poi- } \\
\text { kulitic } \\
\text { large } \\
\text { with } \\
\text { plagio- } \\
\text { clase in- } \\
\text { clusions }\end{array}$ & $\begin{array}{l}18 \text { biotite, } \\
12 \text { horn- } \\
\text { biende }\end{array}$ & $\begin{array}{l}0.3 \text { magnetite } \\
\text { sphene } \\
\text { feucoxene }\end{array}$ & $\begin{array}{l}\text { Partly } \\
\text { sericitized }\end{array}$ & $\begin{array}{l}\text { Summit } \\
\text { Lake, } \\
\text { south side, } \\
1.6 \mathrm{~km} \text { from } \\
\text { outlet. }\end{array}$ & \\
\hline Diorite & $\begin{array}{l}\text { Copper } \\
\text { Mitr. plu- } \\
\text { ton }\end{array}$ & $70 \mathrm{C} 426$ & 4 & $60, A n-35$ & 4 & $\begin{array}{l}28 \text { pyro- } \\
\text { xene } \\
\text { tminor } \\
\text { hom- } \\
\text { blende } \\
\text { biotite }\end{array}$ & $\begin{array}{l}1.9 \text { magnetite } \\
2.4 \text { pyrite }\end{array}$ & $\begin{array}{l}\text { Fresh, } \\
\text { cut by } \\
\text { sericite } \\
\text { veinlets }\end{array}$ & $\begin{array}{l}\text { Portage Bay, } \\
\text { south shore, } \\
1,0 \mathrm{~km} \text { from } \\
\text { Gould I. }\end{array}$ & $\begin{array}{l}\text { Border phase } \\
\text { brecciated } \& \\
\text { intruded by } \\
\text { granodiorite } \\
\text { chemical } \\
\text { analyses in } \\
\text { table } 2, \text { No. } \\
19 .\end{array}$ \\
\hline
\end{tabular}


Mountain and a few areas near the margins of the Copper Mountain pluton. This rock is olive green and forms bold outcrops that are darker, nore rounded, and rougher than the average rock of the Copper Mountain pluton. Epidote has replaced gabbro in irregular, rather angular masses that range from a lew millimeters to several meters in diameter. Few epidote velnlets cut the rock. Enlarged masses along the veinlets are believed to be feeders for the epidotization of the gabbro (lig. 21). Ln thin section the replacement origh of the epidote masses is clearly shown by the gradational embayed contacts with the gabbro. The gabbro is made up of medium-sized subhedral crystals of labradorite (An-555 ), smaller amounts of hornblende and pyroxene, and minor ilmenite(?), sphene, and apotite. Much of the plagioclase has been slight]y sericitized. The epldote masses embay the surrounding gabbro and contain relict gabbro minerals in their outer portions.

The progressive alteration of accessory magnetite also demonstrates the replacement origin of the epidote masses. Magnetlte gralns are unaltered in Presh gabbro but have thin rims of spirene near epidote masses and are seamed with chlorite. In the outer $5 \mathrm{~mm}$ of the masses, the magnetite grains become progressively more dilorltized. The resultant rock within the $5-\mathrm{mm}$ transition zone is granular epldote with scattered, rounded, sphene-rimmed chlorite grains of the same irregular shape and size as the accessory magnetite in the fresh gabbro.

The gabbro and diorlte were probably epldotized shorly after intrusion and solidification-about the same time that pyrometasomatism occurred in the surrounding bedded rocks. One chemical sualysis of epidotized gabbro near Gould Island (table 1, No.

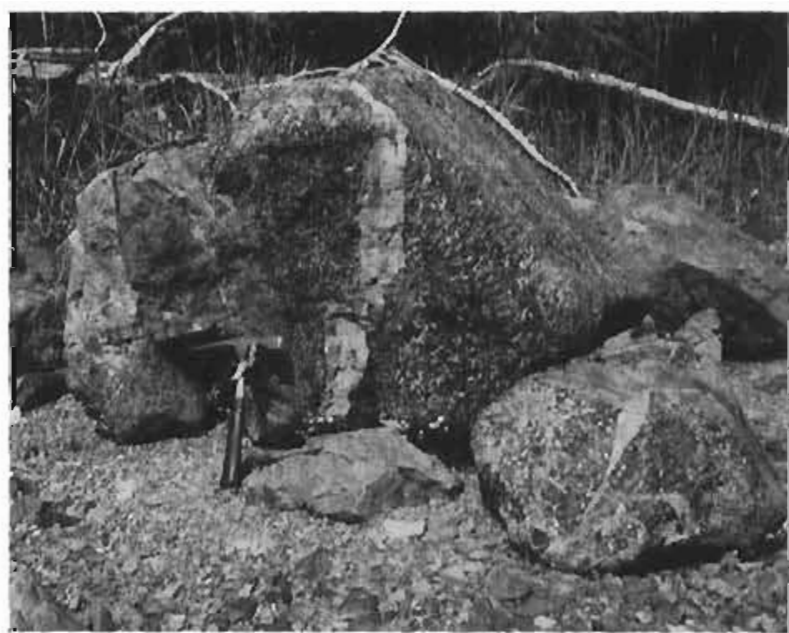

Figure 20. Migmatite from the marginal zone of the Copper Mounlain pluton. Beach baulders nearly in place on the southwest shore of Gould Island show fine-grained diorite, coarse-grained amphibolite, and aplite veins.

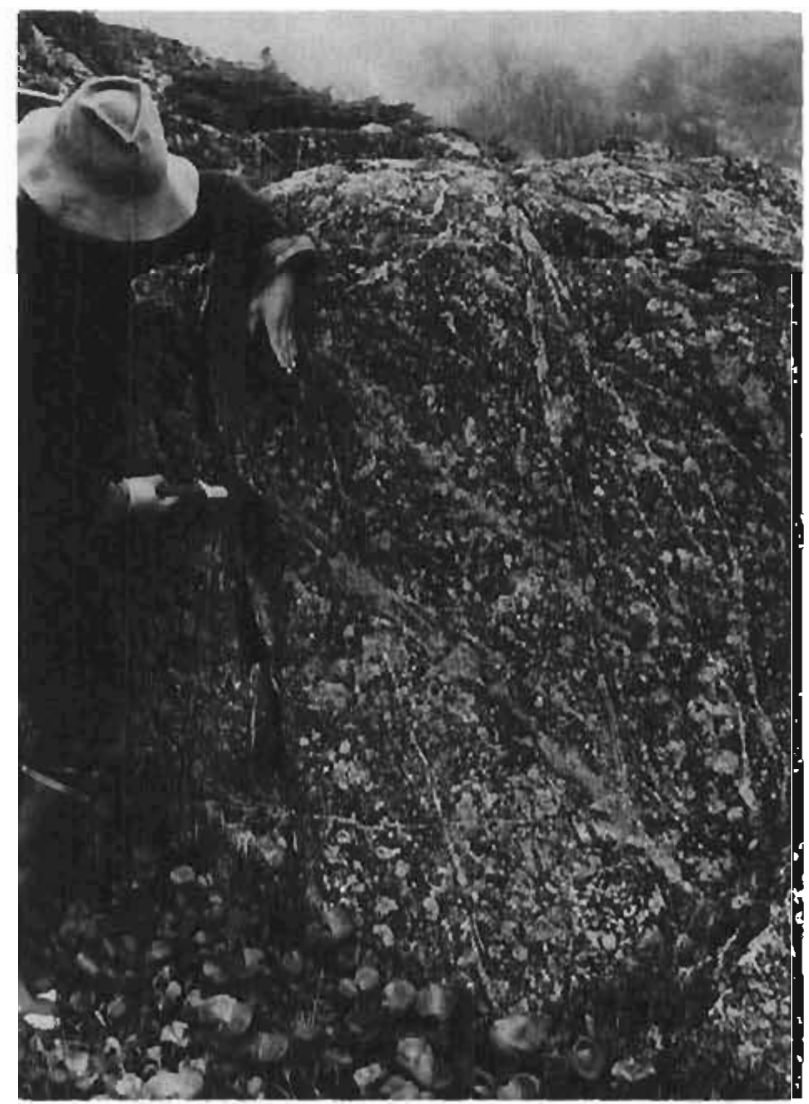

Figure 21. Epidotized gabbro on the ridge west of Lake Marge. Lighter colored masses are epidole. A few $0.5-$ to $25 \cdot \mathrm{cm}$-thick feldspar quartz veins with miniseule amounts of chalcopyrite are present along this ridge.

17) suggests that $\mathrm{SiO}_{2}$ has left the system and $\mathrm{CaO}$ has entered it.

\section{BRECCIA DIKES (Kbd)}

Fragmental dikes, $15 \mathrm{~cm}$ to $60 \mathrm{~m}$ thick, occur on Klakas Inlet near small porphyritic diorite plutons (Kdip) and intrude dark-gray Devonian siltstone and argilite $(\mathrm{Dz})$. Clasts are rounded to angular, usually 2 to $6 \mathrm{~cm}$ in diameter, but range from sand size to $30 \mathrm{~cm}$ long. The clasts are syenitic felsite, porphyry tic alaskite, dark-gray slate, and massive fine-grained pyrite. They fit compactly in a sparce chlorite matrix and are veined and partly replaced by carbonate; there is no quartz or pyrite velning. Although the breccia dikes in the Devonian sediments have not deformed thin siltstone beds, larger clasts have deformed the walls in a few places.

The breccia dikes were probably emplaced by surges of high-pressure $\mathrm{CO}_{2}$-rich gas charged with rock fragments from bedrock at depth. Such an origin is com patible with the rounded to angular shape and lace of 
sorting of the fragments, the lack of quartz veining, and the presence of carbonate illteration. The alaskite and syenilic relsite are prohably derived from Silurian or older alaskite and granitic rocks (Sgd, Sa) below the preDevonian unconformity.

\section{AGE}

Six hornblende and biotite separates of the grano. diorite (Kgdi) plutons throughout the Craig A-2 quadrangle yield concordant ages averaging $102 \mathrm{~m} . \mathrm{y}$. This age is believed to approximate the time and emplaceinent and crystallization of the plutons (Turner and others, 1977). Contact relationships suggest (Jat the Keg plutons intruded before the main $\mathrm{Kgdi}$ intrusive event.

Altered porphyritic diorite (Kdip) is younger than the Lower Devonian and, judging from its lithologic affinities to the Kgdi plutons, probably representis an eaxly manifestation of Cretaceous magma generation. These rocks, however, are too altered to be suilable for the $40 \mathrm{~K}^{-40}$ Ar age-dating ine thod. Breccia dikes (KDd) are thought to be Cretaceous for the same reason.

\section{THERMALLY METAMORPHOSED ROCKS}

\section{HORNFELS (Kh)}

An aureole of hornfels surrounds the Copper Mountain pluton (Kgdi) and its outliers at Helta Lake, Gould Lsland, and north of Portage Bay. Hornfels aureoles also surround epidotized gabbro (Keg) and the granodiorite (Krdi) pluton at 2546 mountain near the Keete Inlet thrust. Near the intrusive the aureole is garnet-bearing hornblende hornfels grading inco atbice-epidote hornfels away from the plutonic body.

Metalliferons skarns derived from calcareous and igneous rocks have been discussed in detail by Wright (1915) and Kennedy (1953); some are described in the mineral deposits section (p. 32-4.6).

The hornfels aureole is well exposed at the west end of Gould Island. Here, at the outer edge, the intrusive is gabbro with epidote clots and pyrometasomatic acicular homblende crystals up to $15 \mathrm{~cm}$ long.

Near the conlact with the gabbro, the hornfels is greenish black and composcd of fine, nondirectional grains of biotile, magnetite, and apatite in a turbid granoblastic quartiz-andesine matrix. This rock is cul by numerous irregular quartz veins. These have margins of granoblastic quartz and irregular cores of sieve-textured diopside(?), garnet, and hornblende. The garnet-cored veins are ubiquitous near the intrusives and indicale that the inner aureole belongs to the hornblendehornfels metamorphic lacics. In the field the reddish garnel-cored veins with white margins mark this facies clearly.

Al the west end of Gould Island, the inner zone of hornblende-hornlels gives way to an outer zone of albite-epidote hornfels at distances of 150 to $600 \mathrm{~m}$ from the contact. The albite epidote hornfels is a finegrained, dark-gray to greenish-black rock composed of randomly oriented biotite in a fine-grained matrix of quartz and feldspar. Scatlered relict albite phenocrysts suggest the original rock was green tuffaceous schist (Wg) of the Wales Group. In the outer part of the albite-epidute hornfels zone, near the northwest end of Gould Island, the original fine-grained green tuffaceous(?) schist is largely replaced by chlorile and magnelite and the rock is cul by epidote veinlets.

The ouler margin of the aureole is well exposed on the coast of Helta Inlet, just $100 \mathrm{~m}$ east of Dell Island, where green luflaceous(?) schist is silicified, has rusty pyritized zones, epidote veinlets and patches, and seams of sericite, magnetite(?), and chlorite that parallel loliation. The relict albite phenocrysts(?) are cloudy, poorly twinned, and were not noticed in outcrop. On Dell Island itself the green tuffaceous(?) schist is fresh appearing and has 5 percent twinned macroscopic albite. The felsic groundmass is about the same in the two rocks.

The depth of formation of the horntels is probably $3 \mathrm{~km}$ or less; this estimation is based on the contact metamorphic mineral assembledges on Green Monster Mountain, where there is a $30 \cdot \mathrm{m}$-wide band of monticellite, calcite, chlorite, and sericite skarn along the east contact of the epidotized gabbro. According to Winkler (1967, p. 44) "at temperatures realized in nature, montecellite can form only at very low $\mathrm{CO}_{2}$ pressures, at most, a few hundred bars." A depth of $1 \mathrm{~km}$ in average rock is equal to a geostatic pressure of 250 bars.

The geometry of the hornfels at Copper Mountain and mountain 2525 plutons suggest that these intrusions may have angled up from depth at a northwest-southeast plunge ( $p l .1)$. The hornfels zones are wide (up to $6 \mathrm{~km}$ ) on the southeast edges of the plutons and narrow $(<1 \mathrm{~km}$ ) on the northwest edges.

The porphyrilic diorite plutons (Kdip) have minor irregular hornfels zones, sometimes only a few meters thick. In some areas homfels are near (but nol along) the igneous contact. These bodies were apparently intruded to very shallow depths, as indicated by the breccia dikes (Kbd) along Klakas Inlet west of Max Cove, where very little thermal alteration of country rack occurred during intiusion and where little (if any) hornfels was formed.

\section{ACTINOLITIC HORNFELS (Kah)}

A sheet of hornfels up to $150 \mathrm{~m}$ thick caps the ridge northeast of Hetla Lake. The hornfels (Kah) is a fineto medium-grained, nearly unfoliated, and unbanded dark-greenish-gray rock composed of unoriented acicular actinolite, albite, epidote, and leucoxene-ilmenite mineralogy. Along the westem and northem edges, the 
gently dipping sheet is distinctly dipferent from lhe underlying thick-bedded and steeply dipping sequences of hornfels and marble (pl. 1). The edge of the sheet, which is thin and underlain by marble, is much broken by solution pits in the marble. Many of these pits have marble on the botlom and amphibolite on the rim. 'The surface of the underlying ruck was uneven when the overlying sheet was emplaced. In the exposures at the north end of the sheet, the actinolitic hornfels is a mas. sive metabasite either in thrust contact with or unconformably overlying older bedded rocks. The sheet recrystallized without developing much foliation because of the lack of shearing in the massive unit. Along the eastern contact with the Wales Group, the aclinolite hornlels becomes banded with quartzose layers and is difficult lo distinguish from the normal Wales Group green schist.

\section{AGE}

Hornfels (Kh) is believed to have lormed at the same time or alter the crystallization of the Copper Mountain pluton (Cretaceous). A $40 \mathrm{~K}^{-40}$ Ar radiometric age of actinolite in the actinolite hornfels (Kah) near Hetta Lake of $216 \pm 4 \mathrm{~m} . \mathrm{y}$. (Turner and others, 1977) suggests that the Cretaceous Copper Mountain pluton has partially reset the radiometric age from the Middle Ordovician thermal event.

A sample of actinolite-bearing hornlels (Kh) from Dell Island gave an apparent age of $141+4 \mathrm{~m}$.y. (Tumer and others, 1977) and is believed to represent a nearly complete resetting of the Wales Group metamorphic age by the emplacement of the Copper Mouniain pluton.

A zone of biotite hornfels crops out for a short distance along the west side of Cholmondeley Sound. Biotite in the hornfelsed zone is discordant to foliation in the Wales Group schist country rock. This biatite was dated at $355 \pm 11 \mathrm{~m} . \mathrm{y}$. (Turner and others, 1977). There is no exposed intrusive body in the area that could account for the hornfels. The apparent age represents either 1) a partial reselting of the 475-m.y.old Wales Group metamorphic age or 2) the thermal manifesta. tions of a buried Paleozoic intrusive.

\section{STRUCTURE}

\section{SMALLSCALE FEATURES ASSOCI ATED WITH PENETRATIVE DEFORMATION}

\section{FOLIATION}

Foliation occurs pervasively in the Wales Group but is rarely found in the Descon Formation. The foliation in the Wales Group is due to parallel orientation of cilorite flakes that payallel composition layers in most outcrops. Only rarely does foliation cut compositional banding. In most localities the compositional layering in the Wales Group represents original bedding that ranges from vague color bands to well-defined beds of metakcratophyre, tuifaceous schist, and marble. Most of the Wales Group green schist $(\mathrm{Wg})$ is made up of atternating llyin quartzose and chloritic laminae.

\section{CRENULATIONS}

In much of the Wales Group are crenulations about $1 \mathrm{~mm}$ apart with axes parallel to nearby minor folds. In some outcrops two directions of crenulations are visible on different layers. Commonly there are chioritic streaks on foliation surfaces that parallel crenulations or define a second direction of lineation.

In many outcrops crenulations are deflected by later small folds or kink bands with axes parallel to the crenulations. The early (E) and late (L) linear features in figure 22 show that later small fold or kink bands deflect earlier crenulations. Apparently, there were two periods of penetrative deformation, with much wobble in axial direction.

\section{MINOR FOLDS}

Minor folds in the Wales Group are usually 2 to 15 $\mathrm{cm}$ in wavelength. Most are recumbent so that in pro. Dle, they are $S$ or $Z$ shaped, having formed during periods of penetrative rotational shear. The local direction of rotation is perpendicular to the fold axes. The colds (pl. 1), as seen looking down the plunge of the fold axis.

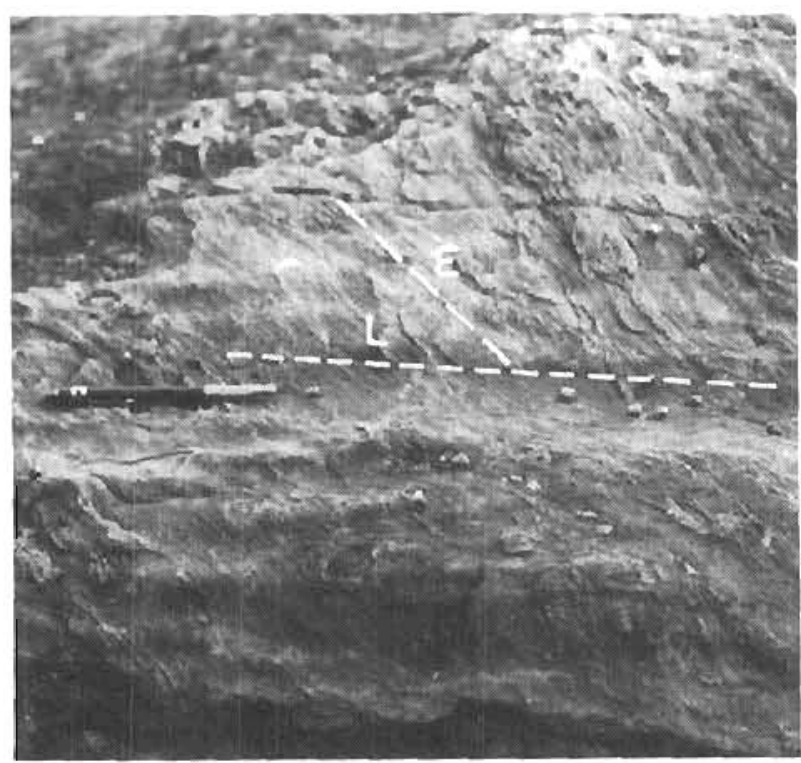

Figure 22. Foliation surface in Wales Group green schist. Earlier erenulalions (E) are gently folded by later, nearly horizontal folds (L) at the northwest comer of Kassa Inlet. 
Minor folds are a conmon feature of penetrative regional deformation. Minor folds in one oulcrop are usually pacallel to crenulations and chloritic streaking in nearby outcrops.

\section{BOUDINAGE}

Many dolomite and quartz layers in the Wales Group units show boudinage structure. This is well illustrated by dolomite layers on the north side of West Arm thint lave been pulled apart and show 'sucking-in' of the adjacent marble at necked parts and around the ends of the boudin. The boudins are up to $3 \mathrm{~m}$ thick and $20 \mathrm{~m}$ long. Their long axes are steep (S. $80^{\circ} \mathrm{W} ., 85^{\circ} \mathrm{plunge}$ ) and parallet the early lold axes.

\section{KINK BANDS}

The latest structural features in the Wales Group are crosscutling zones of kinking in the foliation that form bands a lew centimeters thick. Both single and multiple bands that split and join are found. These kink bands occasionally grade into cleavage and secondary foliation (fig. 23). Axes of kink bands are shown on place 1 .

\section{LARGE-SCALE IAULTS AND FOLDS}

\section{THRUST FAULTS}

The Big River thrust sleet is a complexly folded and faulted sheet of Wales Group marble (Wm), dark-gray phyllite (Wp), and minor greenschist (Wg) that has been thrust over the Wales Group green schist (Wg) and quartz sericite schist (Ws) at the lime of or before regional folding. Thrusting has been definitely identified only near Big Rlver. In other places Coliation and bedding in the thrust sheet are more or less parallel to loliation in the rock units, although the thrust conlacl shows extreme shearing in these localities.

On the slope southwest of the mouth of Big River (pi. 1), the thrust surface truncates Wales Group units below it at an angle of $40^{\circ}$. A greenschist layer in the Wales Group marble (Wm) above the thrust is also truncated. Two $\mathrm{km}$ to the south, two thick marble beds (Wm) in the lower plate strike into the thrust and are apparently truncated.

A thrust system crosses the east shoreline of Helta Inlet south of Jumbo Creek in an area of unusually abundant colds. These folds are parallel to the earlier

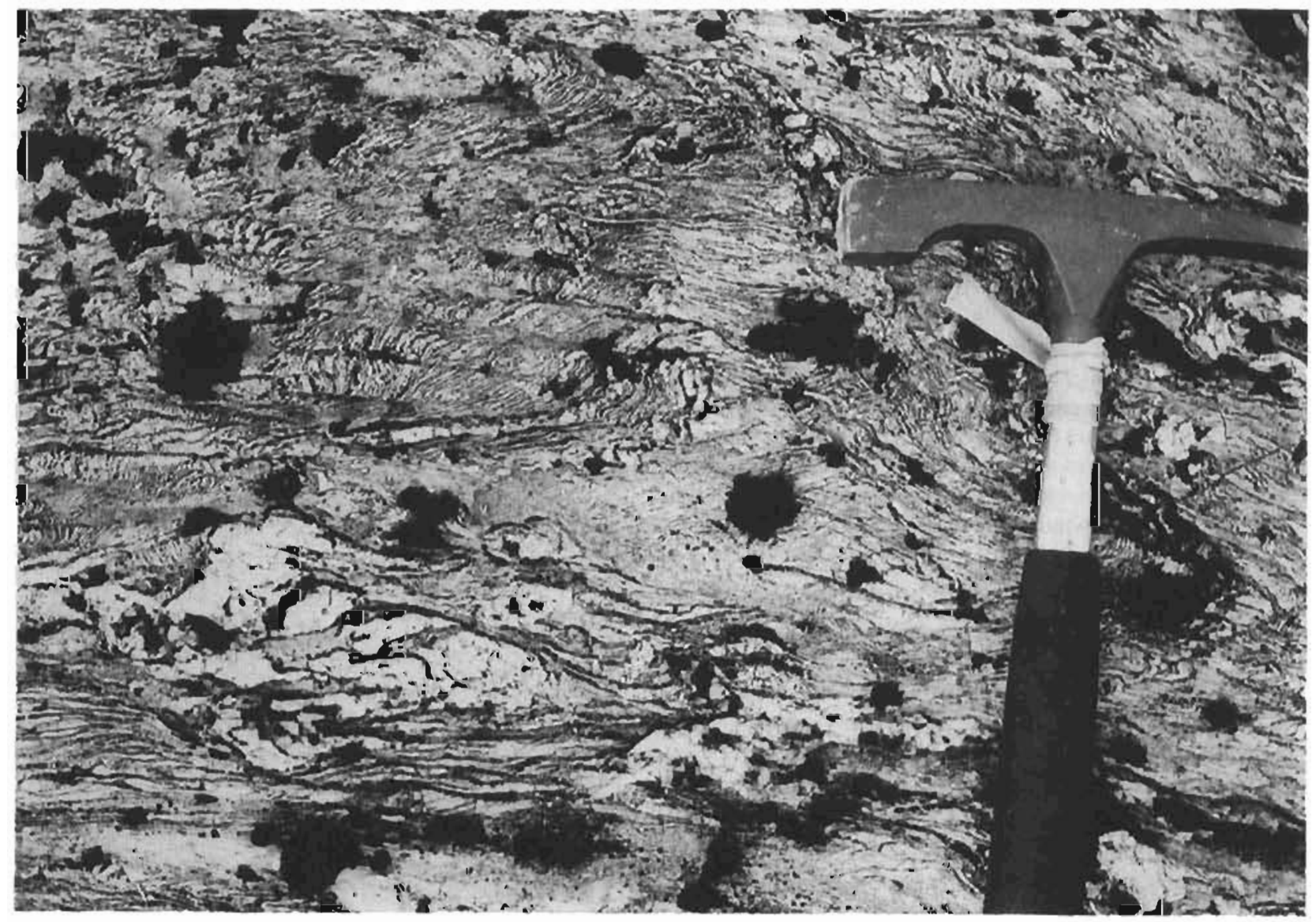

Figure 23. Silicious Wales Group Schist near Summit Lake. Drag-folded quartz is cut by younger cleavage. 
minor fold direction nearby, which suggests that the thrusting occurred at the same time as the penetrative deformation (synkinematic thrusting). The folds are overtumed to the east.

Thick sections of interbedded marble and hornfels (Kh) east of Summit Lake, northeast of Helta Lake, and at Hetta Mountain may be faulted parts of the Big River thrust sheel. The well-defined hornfels sheet (Kah) northeast of Hetta Lake rests partly on the Big River thrust sheet.

At the west end of West Arm, marble Pault blocks (pl. 1) are interpreted as part of the Big River thrust sheet dropped down along normal faults. These faults are about vertical and cut across bedding in the marble. Farther east, at Divide Head and across on the north shore of West Arm, horst and graben normal faulting dies out and the Big River thrust fault is exposed. The thrust sheet bere has been folded into a synctine. The marble is parallel with the underlying schist and partiy dolomitized.

The Keete Inlet thrust brings Wales Group schist under unmetamorphosed Lower Devonian and Descon Formation rocks. The nature of the fault movement is based on the following observations: 1) the fault, where measureable, dips under the sediments and away from the Wales Group rock units at roughly $25.40^{\circ}, 2$ ) its strong curvature, which causes a $90^{\circ}$ change in direction in $14 \mathrm{~km}$, indicates that it is a shallow-dipping fault, and 3) both the pervasive shearing of the Wales Group green schist for up to $450 \mathrm{~m}$ from the fault and the lack of shearing in the sediments on Keete Inlet indicate that the dip-slip movement was thrusting and that the green schist was an active agent.

\section{AGE OF THRUSTING}

The Big River thrust sheet probably moved contemporaneous with the latest major folding episode in the layered rock section. This is suggested by the parallelism of larger scale folds in the thrust sheet with those in the underlying rocks. In addition the thrust is folded into a syncline near Big River. Movement on the thrust sheet northeast of Hetta Lake evidently ceased before Cretaceous plutonism.

The Keete Inlet thrust clearly cuts Middle Devonian sedimentary rocks but is intruded by a Cretaceous granodiorite (Kgdi). Thus the age of thrusting in the map area is believed to have taken place during a post-Middle Devonian-pre-Gretaceous interval. Some minor low. angle movement along older thrust faults may have occurred during intrusion of the Copper Mountain pluton.

\section{HIGH-ANGLE FAULTS}

The map area is cut by north and northwest-trending steep faulis. The Klakas Inlet fault is the clearest example of a north-trending pault. A left-lateral strike. slip movement of $2-1 / 2 \mathrm{~km}$ is shown by offset of the lower sheet of the Keete Inlet thrust. On the divide between Klakas Inlet and South Arm, the fault has a vertical shear zone $1 \mathrm{~m}$ wide that trends north from Klakas Intet to the south half of South Am and is probably offset by a northwest-trending cross fault at West Arm near Cholmondeley Sound. It apparently does not extend across West Arm.

Prominent nortbwest-trending lineaments extend through the southern part of Prince of Wales Island. Several major northwest-trending lault zones that extend for a number of kilometers in the map area include the East Finger, Deer Bay, and West Arm faults.

The north-trending high-angle paults are generally cut by the more prominent northwest-trending fracture series. Neither set appears to have significant stratigraphic displacement, although both sets produced offsets of up to $5 \mathrm{~km}$. Radial high-angle faulting adjacent to the Copper Mountain pluton likely resulted from stress created by the intrusive episode in Cretaceous time.

\section{FOLDS}

The Wales Group has undergone two periods of folding, the latter of which warped the Wales Group, the Descon Formation, and the Middle Devonian rocks into rather broad northwest-trending fold structures. A regional anticline, possibly the Dolomi-Sulzer anticline (Peek, 1975), may be the axis of a broad northwest. plunging anticlinorium that shapes the present configuration of Wales Group rocks in the map area (pl. 1). These larger fold structures have been complicated by several periods of thrust faulting and high-angle fracturing.

\section{WHOLE-ROCK MAJOR OXIDE ANALYSES OF IGNEOUS ROCKS}

Whole-rock chemical analyses of 12 plutonic, volcanic, and metavolcanic rocks are given (table 2 ) and shown on triangular alkali-F-M diagrams and an alkall silica diagram (fig. 24-27). The results of the analyses have been discussed individually in the rock-unit sections of the text.

\section{ELEMENTAL GEOCHEMISTRY}

The geochemical sampling and trace-elements analysis program was aimed at determining the metal content of the Wales Group rocks and defining mineralized zones within the map area. In an area of about $740 \mathrm{~km}^{2}, 1,130$ stream-sediment and soil samples (table 3$)^{4}$ and 140 rock samples (table 4$)^{4}$ were taken for 30 -element analysis. Rock samples were composite chip samples taken of shoreline outcrops of Wales Group rocks and channel samples from mineralized zones and prospects.

${ }^{4}$ Tables in back-cover pocket. 
Table 2. Bulk chemical analyses of 12 plutonic, volcanic, and metavolcanic rocks from the Craig A.2 quadrangie and vicinity, and 13 examples from literature

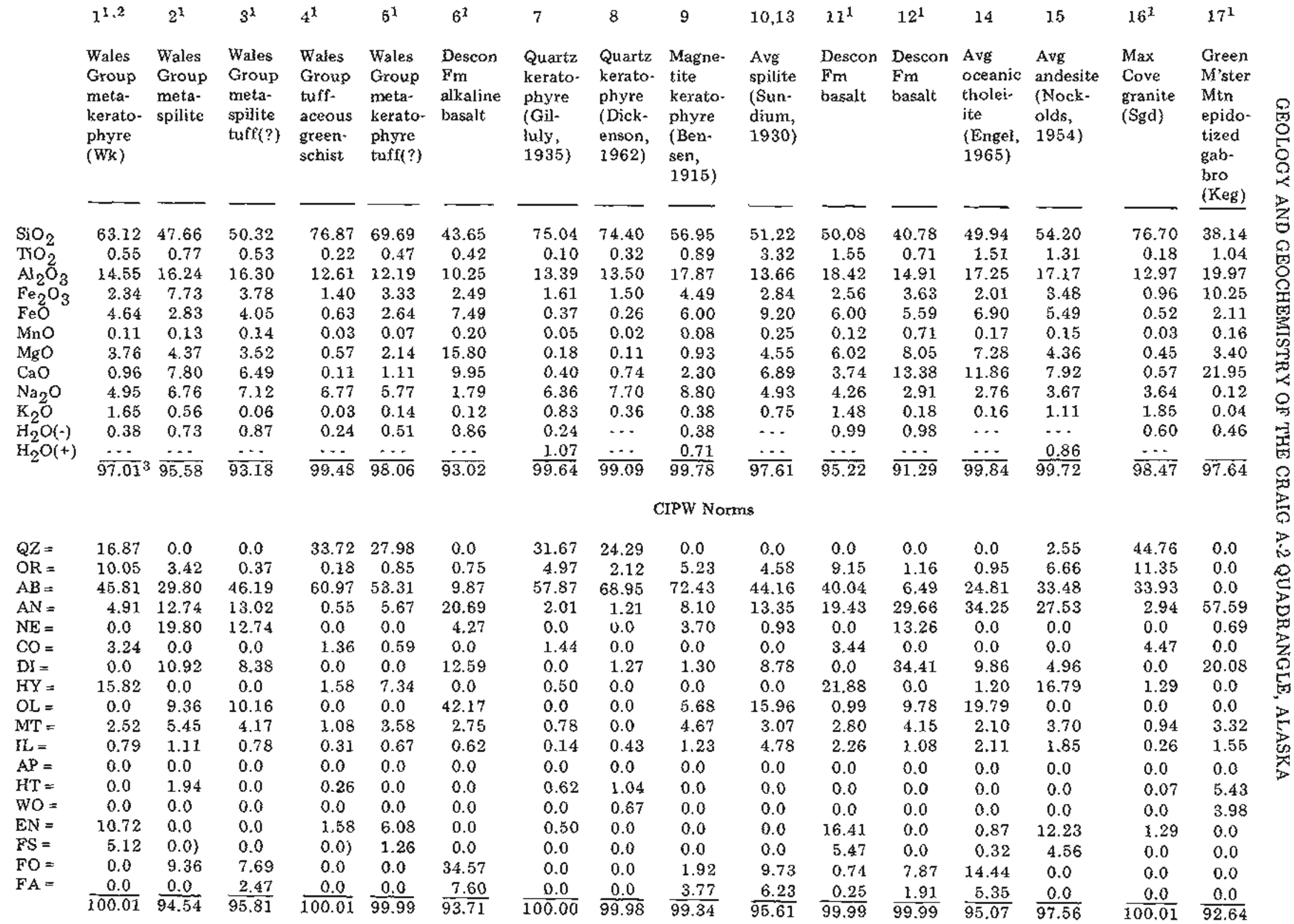




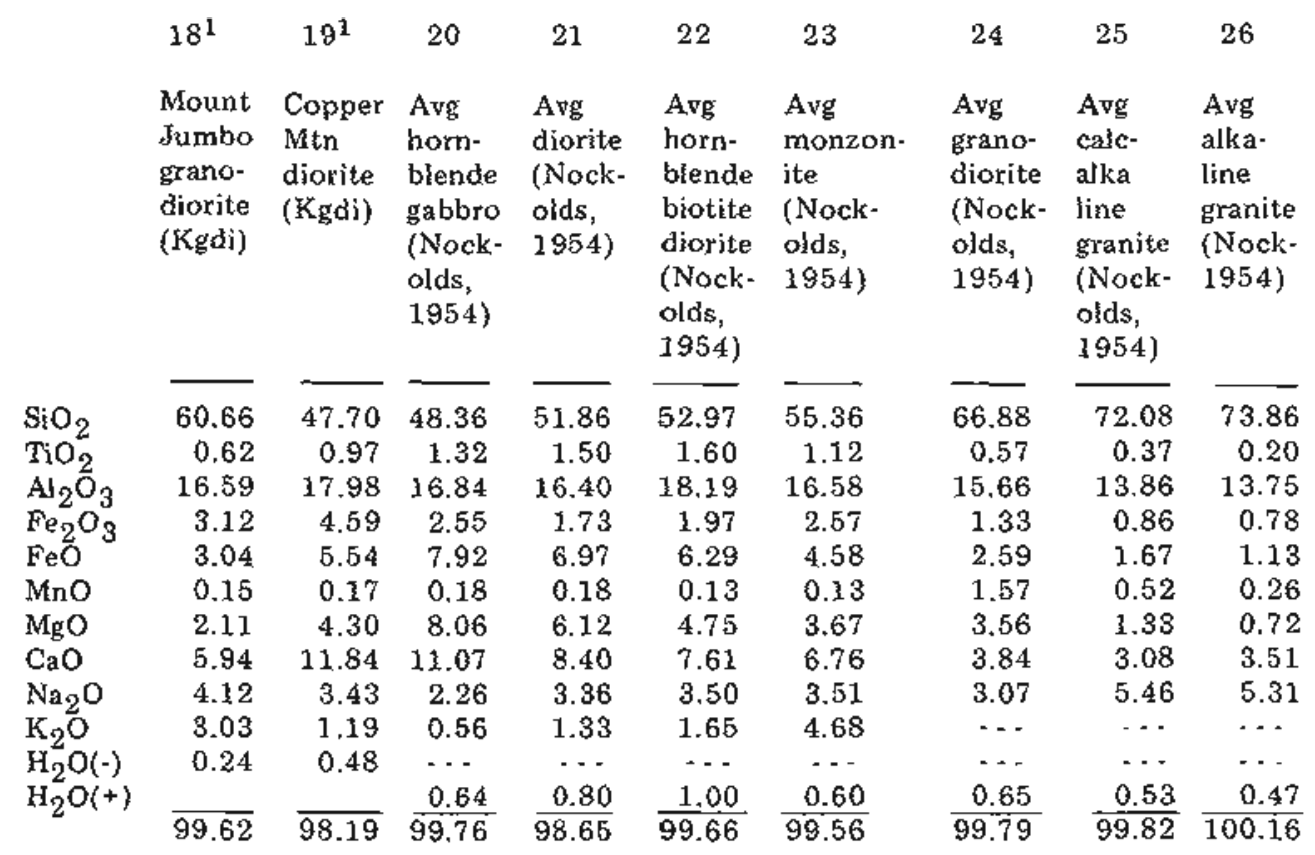

\begin{tabular}{lccccccccc}
$\mathrm{QZ}=$ & 10.01 & 0.0 & 0.0 & 0.0 & 0.0 & 0.0 & 20.21 & 27.19 & 29.48 \\
$\mathrm{OR}=$ & 18.05 & 7.22 & 3.34 & 8.01 & 9.87 & 27.87 & 18.39 & 32.88 & 30.78 \\
$\mathrm{AB}=$ & 37.31 & 23.42 & 20.50 & 30.75 & 31.83 & 28.84 & 34.95 & 28.19 & 32.01 \\
$\mathrm{AN}=$ & 17.98 & 30.97 & 34.51 & 26.24 & 29.43 & 15.79 & 16.65 & 6.73 & 3.63 \\
$\mathrm{NE}=$ & 0.0 & 4.93 & 0.0 & 0.0 & 0.0 & 1.75 & 0.0 & 0.0 & 0.0 \\
$\mathrm{CO}=$ & 0.0 & 0.0 & 0.0 & 0.0 & 0.0 & 0.0 & 0.0 & 0.52 & 1.24 \\
$\mathrm{DI}=$ & 9.30 & 23.49 & 8.39 & 6.50 & 3.53 & 7.21 & 0.50 & 0.0 & 0.0 \\
$\mathrm{HY}=$ & 3.10 & 0.0 & 3.49 & 9.68 & 17.78 & 0.0 & 6.83 & 3.06 & 1.75 \\
$\mathrm{OL}=$ & 0.0 & 3.65 & 21.02 & 11.61 & 1.45 & 10.65 & 0.0 & 0.0 & 0.0 \\
$\mathrm{MT}=$ & 3.29 & 4.93 & 2.69 & 1.84 & 2.09 & 2.71 & 1.41 & 0.92 & 0.83 \\
$\mathrm{IL}=$ & 0.87 & 1.39 & 1.86 & 2.13 & 2.26 & 1.57 & 0.80 & 0.53 & 0.28 \\
$\mathrm{AP}=$ & 0.0 & 0.0 & 0.0 & 0.0 & 0.0 & 0.0 & 0.0 & 0.0 & 0.0 \\
$\mathrm{HT}=$ & 0.0 & 0.0 & 0.0 & 0.0 & 0.0 & 0.0 & 0.0 & 0.0 & 0.0 \\
$\mathrm{WO}=$ & 0.0 & 0.0 & 0.0 & 0.0 & 0.0 & 0.0 & 0.0 & 0.0 & 0.0 \\
$\mathrm{EN}=$ & 2.34 & 0.0 & 2.49 & 6.63 & 11.98 & 0.0 & 4.39 & 1.46 & 0.73 \\
$\mathrm{FS}=$ & 0.76 & 0.0 & 1.00 & 3.06 & 5.80 & 0.0 & 2.43 & 1.60 & 1.02 \\
$\mathrm{FO}=$ & 0.0 & 2.68 & 15.00 & 7.95 & 0.98 & 7.66 & 0.0 & 0.0 & 0.0 \\
$\mathrm{FA}=$ & 0.0 & 0.97 & 6.02 & 3.66 & 0.47 & 2.98 & 0.0 & 0.0 & 0.0 \\
\hline & 100.00 & 100.00 & 95.8 & $96.7 \overline{6}$ & 98.24 & 96.39 & 99.74 & 100.02 & 100.00
\end{tabular}




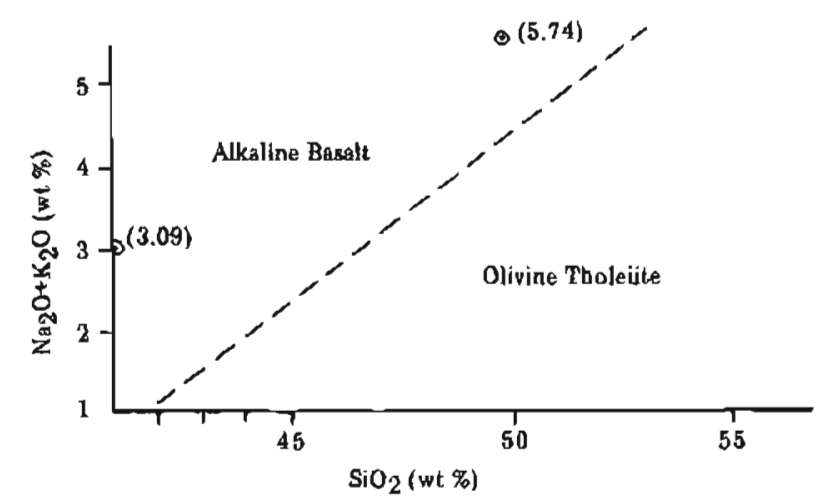

Figure 24. Alkalj-silica diagram for Hawaiian basalts (after MacDonald and Katsura, 1964) and two analyses of Descon basalt (Odb) from Klakas Inlet.

\section{ANALYTICAL TECHNIQUES}

Elemental analyses were performed at the DGGS Mineral Analysis Laboratory. Soil and stream-sediment. samples were screened to -80 mesh and rocks were pulverized. Atomic-absorption analysis was carried out

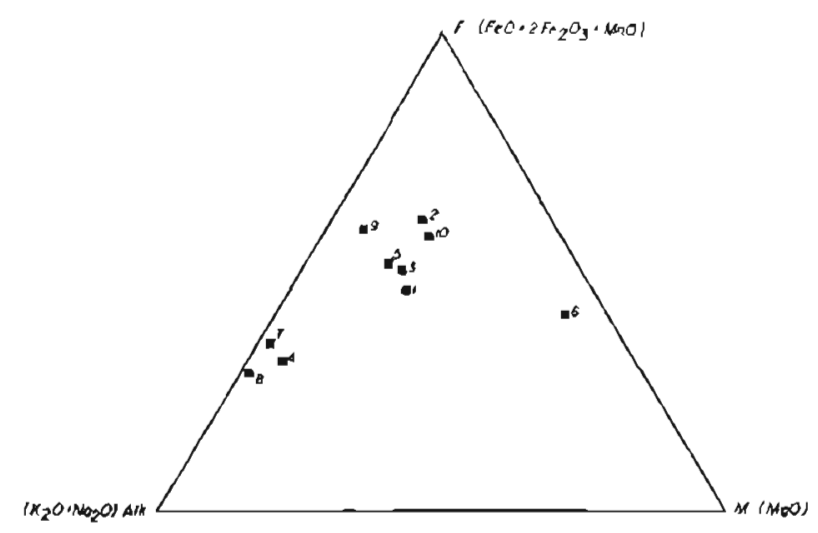

Figure 25. Alkali-F-M diagram of keratophyre tuff and spilite tuff in the Wales Group and from published information. Locations shown on plate 1.1 - Wales Group keratophyre, Nutkwa Inlet (70C 218), 2 . Wales Group metaspilite tuff, Nutkwa Inlet (70C 276). 3 - Wales Group metaspilite tuff, South Arm (71C 165). 4. Wales Group tuffaceous green schist, Hetta Inlet near Deer Bay (72C 174B). 5 - Wales Group metakeratophyre luff, Sukkwan Strait (72C 202B). 6 - Wales Group spilite turf, Sukkwan Strait (72C 202C). 7 - Quartz keratophyre (Guilluly, J, 1953, Amer. Jour. Sci, v. 229, p. 235). 8 - Quartz keratophyre (Dickenson, W.R., 1962, Amer. Jour. Sci, v. 260, p. 261). 9 - Magnetite keratophyre (Benson, N.W., 1915, Linnean Soc.s N.S. Wales Proc., v. 40, p. 199), 10 - Average . spilite, 19 analyses (Sundium, N., 1930, Geol. Mag., จ. 67, p. 9).

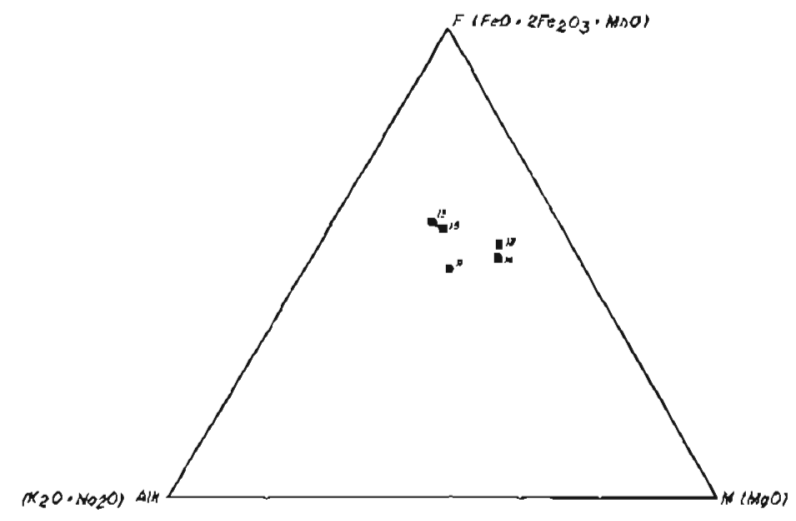

Figure 26. Alkali-F-M diagram of two basalts from the Descon Formation on Klakas Inlet and from pub. lished data. Locations shown on plate 1. 11. Descon Formation basalt from east shore, Klakas Inlet (71C 122). 12 - Descon basalt from west shore, Klakas Inlet (71C 17). 19 - Average spilite, 19 analyses (Sundium, op. cit., p. 9). 14 - Average oceanic tholeiile, 10 analyses (Engel and others, 1965, Geol. Soc. America Bull., v. 76, p. 723). 15 - Average andesite (Nockolds, S.R., 1954, Geol. Soc. America Bull., v. 65, p. 1019).

by taking a 10-g sample and digesting it in an appropriate amount of aqua regia. The digestate was diluted to $100 \mathrm{~mm}$ with distilled water and centrifuged. The elements copper, lead, zinc, and silver were aspirated

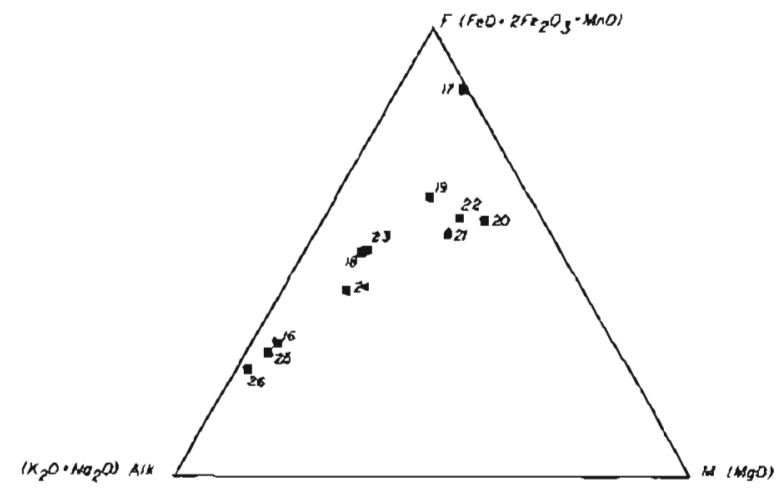

Figure 27. Alkali-F-M diagram of four granitoid rocks. Locations shown on plate 1 . Others taken from literature. 16 . Calc-alkaline granite (Sgd) from west shore, Klakas Inlet near Max Cove (71C 23). 17 . Epidotized gabbro (Keg) from Green Monster Moun. tain (72C 217). 18 - Quartz monzonite (Kgdi) from Mount Jumbo, Copper Mountain pluton (DT72 61A). 19. Diorite (Kgdi) from south shore of Portage Bay, border phase of Copper Mountain pluton (71C 426). 20. Average hornblende gabbro (Nockolds, op. cit., p. 1020). 21 - Average diorite (Nockolds, op. cit., p. 1019). 23 - Average monzonite (Nockolds, op. cit., p. 1017). 24 - Average granodiorite (Nockolds, op cit., p. 1014). 25 - Average calc-alkaline granite (Nockolds, op. cit., p. 1012). 26 - Average alkaline granite (Nockolds, op. cit., p. 1012). 
directly into the air-acetytene flame; gold was determatned following a DIBK-Aliquat 936 solvent-solvent extraction.

Emission spectrographic analyses are reported in a three-step series $1,2,5,10,20,50,100,200$, etc. in ppm or percentage. A reported value of $100 \mathrm{ppm}$ identifies the concentration as nearer 100 ppm than 50 or $200 \mathrm{ppm}$. Approximately 95 percent of the values fall within a \pm 1 reporting interval.

Cumulative frequency plots (figs. 28-30) of the copper, lead, and zinc analyses by atomic-absorption spectrophotometry for the stream sediments and soil samples were made by the method described by Lepeltier (1969). Straight parts of these curves indicate single populations of log-normally distributed sample values. Most of the curves show a positive break, indicating an excess of high values over the log-normal distribution sample values. Thresholds for copper, lead, and zinc anomalies have been taken as the lowest break in the slope of the curve. Anomalous values for elements other than copper, lead, and zinc were obtained by inspection.

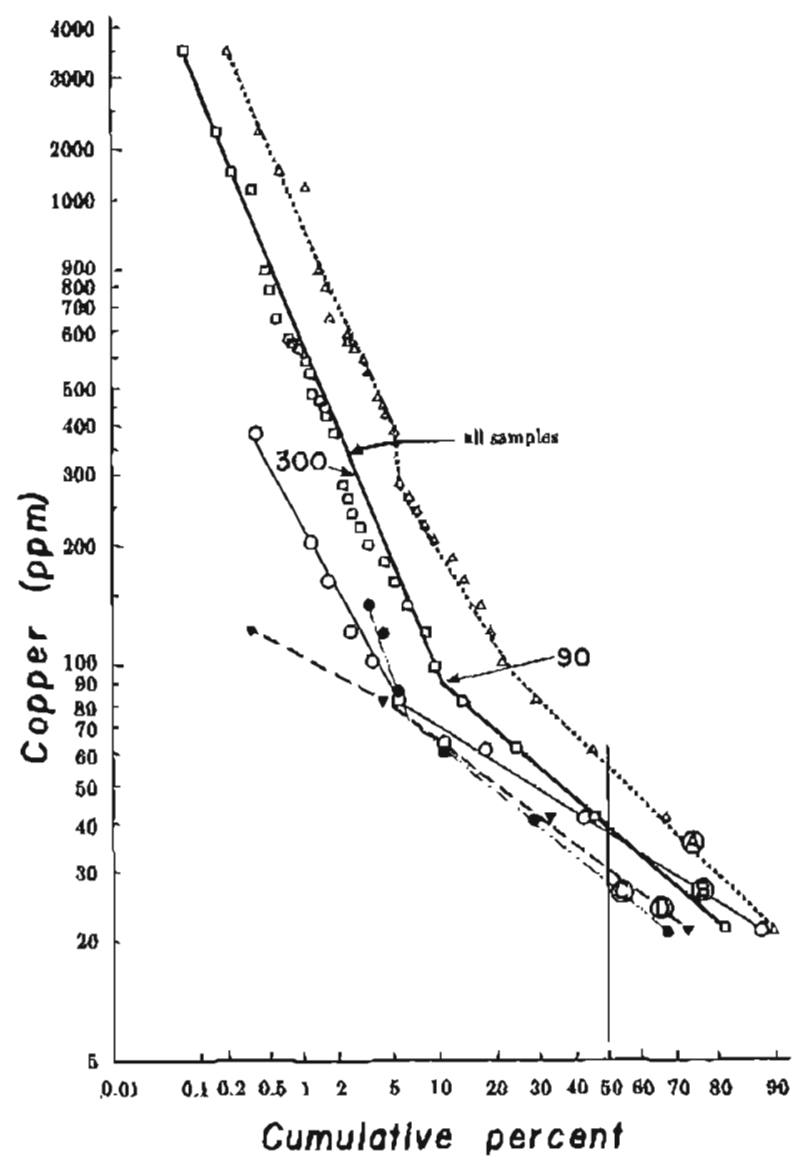

Figure 28, Cumulative frequency plot for copper in stream-sediment and soil samples. A - Copper Mountain subarea. B - Cholmondeley Sound subarea. C Kassa Inlet subarea. D - Klakas Inlet subarea.
Cumulative frequencies were plotted Por the entire area and the four subareas (Copper Mountain, Cholmondeley Sound, Kassa Inlet, Klakas Inlet) shown on plate 2. Three of these subareas are underlain by Wales Group rocks and the fourth includes all rocks south of the Keete Inlet thrust. The cumulative frequency plots show that the Copper Mountain subarea (plot A) has more copper and Cholmondeley Sound (plot B) has more lead and zinc than the rest of the map area.

Stream-sediment samples of the finest fraction available below the water line were taken on creeks at intervals of about $1 / 2 \mathrm{~km}$. All creek-mouth samples draining into salt water were taken well above the hightide line. Soll samples were usually taken in and around prospect areas and mineralized zones. Average depth of soils sampled was about $15 \mathrm{~cm}$. An effort was made to. excluode organic material in all samples.

Confidence in the reproducibility of the streamsediment sampling is given by examining sample results from the mouth of Jumbo Creek and from an unnamed creek at the north end of Hetta Lake. At the latter site (No. 218, pl. 2), an area of low relief and fine sediment, three samples were taken $15 \mathrm{~m}$ apart. Each was divided into three splits and all nine samples were analyzed. The results (table 3 ) show that the variations between sample sites $(56 \mathrm{ppm})$ and the splits of each sample $(10.20 \mathrm{ppm})$ is fairly small compared to the average copper content of the samples (175 ppm). At the moutb of Jumbo Creek (No. 99, p). 2), the copper content of two samples from the creek bed below water level taken. by different samplers 2 years apart was 600 and 675 ppm.

An indication of the effect of location on copper values of these samples (analyzed by atomic absorption spectrophotometry) is shown by three sediment samples taken at site 99 (pl. 2). In the stream bed in $30 \mathrm{~cm}$ of water, $675 \mathrm{ppm} \mathrm{Cu}$ was recorded. In the bank at water level, $745 \mathrm{ppm} \mathrm{Cu}$ was recorded. In the bank $15 \mathrm{~cm}$ above water level, $675 \mathrm{ppm} \mathrm{Cu}$ was recorded. Other elements, notably scandium and molybdenum, show considerably more variability than tho copper in these samples.

Mineralized zones, prospects, and old mines were sampled to obtain an indication of the relative grade of mineral deposits present in the map area. As part of the regional geochemistry program, random grab samples of representative Wales Group rock units were collected along the shores of Kessa, Keete, Hassiah, and Hetta Inlets and Cholmondeley Sound. Because they were analyzed along with the stream sediments, the results obtrined from stream sediments and what is thought to be background metal content in the Wales Group can be compared.

All samples containing anomalous amounts of any of the analyzed metals are shown on plate 2 and described (tables 3 and 4). Background samples taken in 1970 and 1971 are not listed in this report, but can be found in DGGS Geochemical Reports 24 and 27, respectively (Herreid, 1971; Herreid and Trible, 1973). 


\section{ANOMALOUS AREAS}

Peary Creek zinc and lead anomalies cover more than $5 \mathrm{~km}^{2}$ near the Copper Mountain pluton in an area of north- and north west-trending faults that cut marble and dark-gray phyllite bedrock. The gnomalies may be partly due to a high background in the sheared quartz-vejn-rich phyllite, but there may also be undiscovered mineral deposits in the Wales Group there.

Anomalous amounts of copper and other base metals are present in streams draining the pyrometasomatic skarn deposits on the west side of the Copper Mountain pluton. The Jumbo glory hole is near the upper part of
Jumbo Creek, about $2.5 \mathrm{~km}$ Prom the beach. At the mouth of Jumbo Creek, stream sediments average 600 ppm copper. Bedrock for most of this distance is marble, which has not inhibited the transportation of copper in the stream. Samples from Wright Creek, where several small prospects are located, also contain anomalous copper values. In contrast to this, the small creek on the south side of Copper Harbor has no known copper prospects and its sediments are not anomalous at the mouth and only slightly so near its head. There are tungsten anomalies from streams draining the northem portion of the Copper Mountain pluton contact aureole.

Small copper deposits on the east side of the Copper

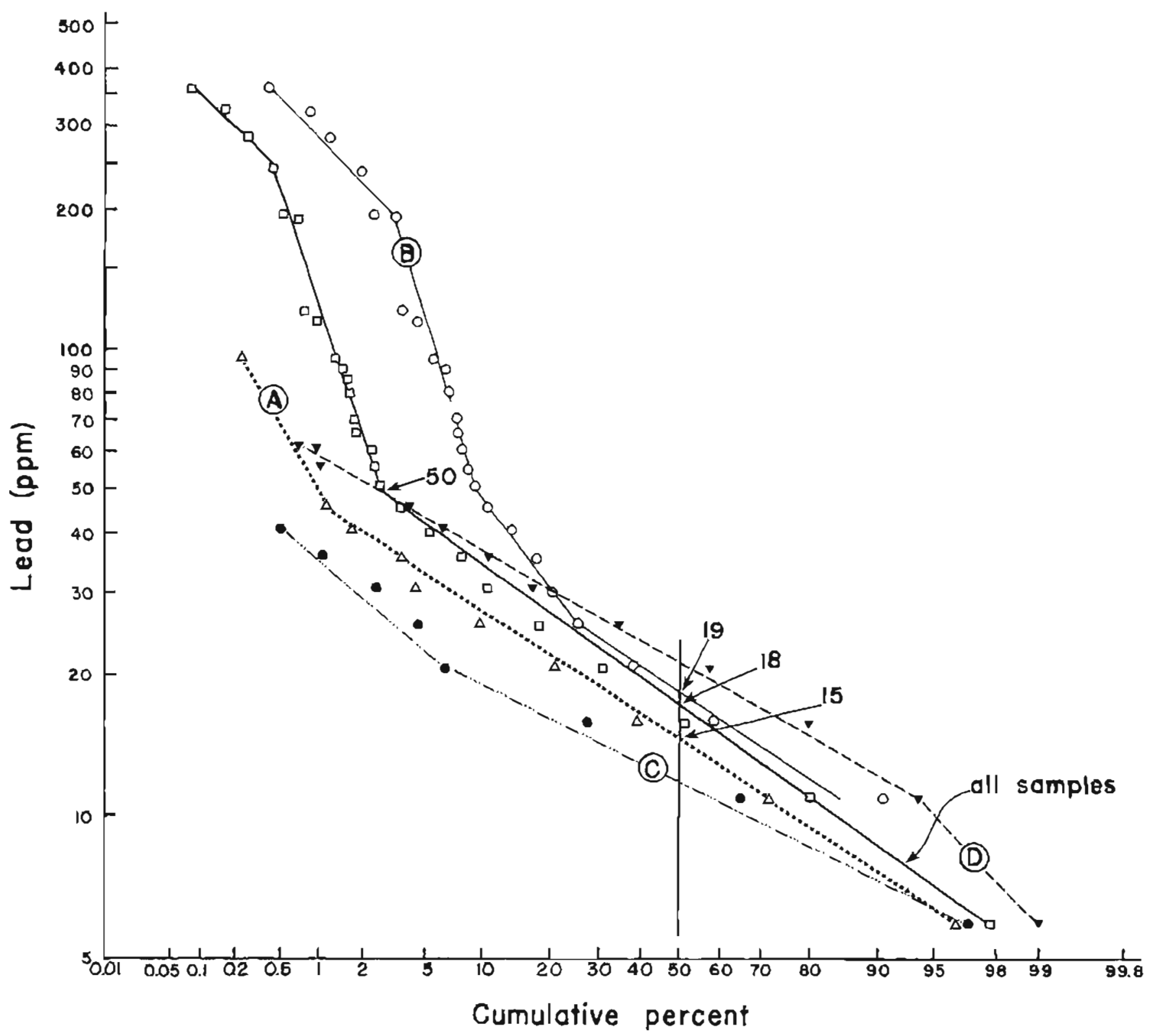

Figure 29. Cumulative frequency plot for lead. A - Copper Mountain subarea. B - Cholmondeley Sound subarea. C Kassa Inlet subarea. D - Klakas Inlet subarea. 
Mountain pluton are mirrored by anomakous copper contents in many of the small streams. The sediments in the 3-km.long creek draining inlo Hetta Lake from the north are anomalous in copper from head to mouth and in molybdenum near its head. Disseminated molybdenite is present in outcrops of skarn at the head of the creek directly west of Lake Marge. This creek would certainly lead the prospector from Hecta Lake to the Lake Marge mineralized area. However, it seems likely that there is more than one source of copper and molybdenum along

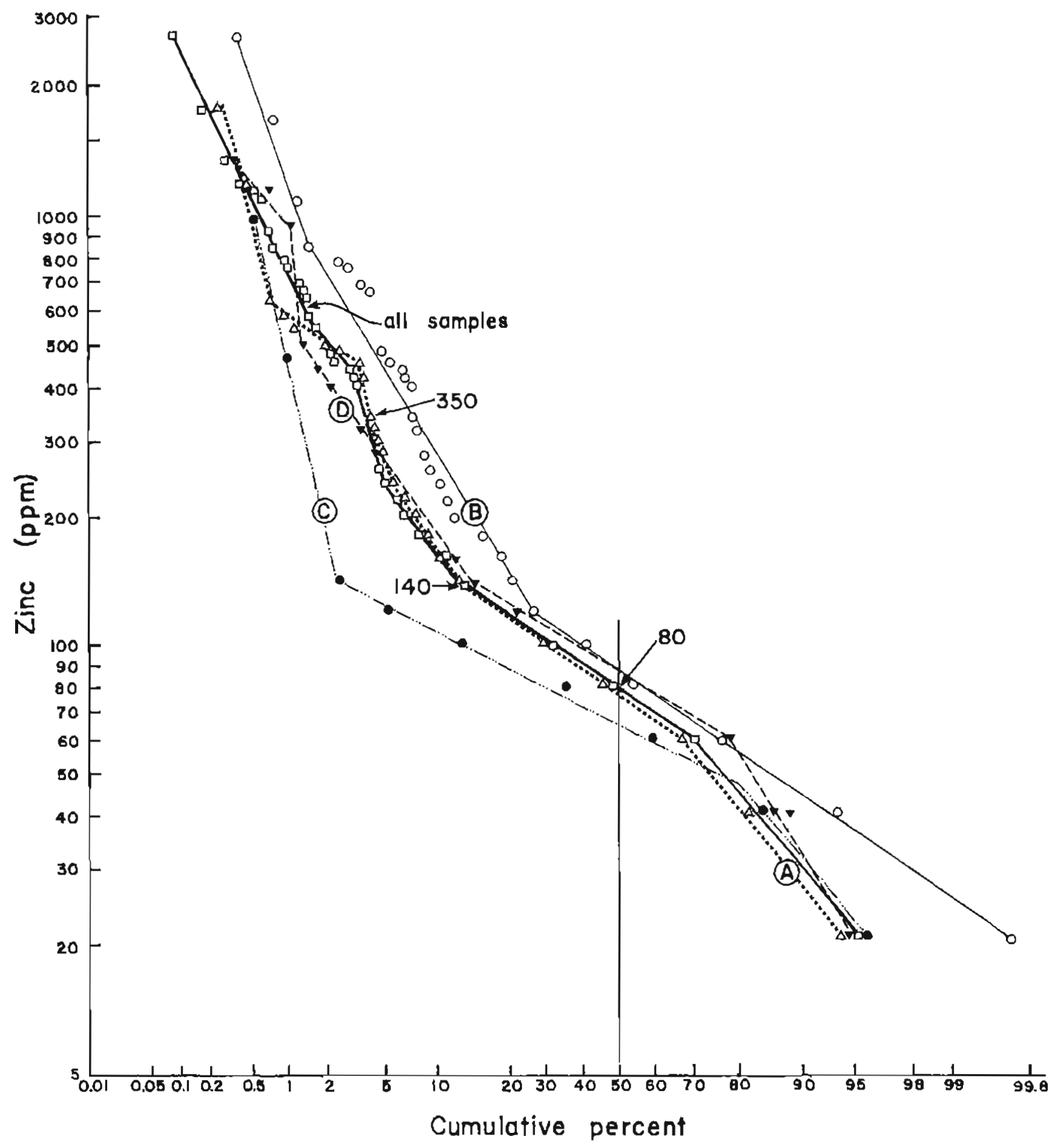

Figure 30. Cumulative frequency plot for zinc. A Copper Mountain subarea. B - Cholmondeiey Sound subarea. C . Kassa Inlet subarea. D - Klakas Inlet subarea. 
the creek drainage and the actual distance of transport of the base metals down the creek may be less than $3 \mathrm{~km}$.

High tin values from streams draining Beaver Mountain at the head of West Arm probably represent a high tin background for the granitic rocks to the nortly of the map area.

Antirnony anomalies from sediments in streams draining the south shore of West Arm may indicate mineral. ization in the Wales Oroup there.

The creek at Chomly townsite on West Arm extends along a north-northeast-trending fault parallel to the Friendship fault. The indicated lead-zinc anomalies there may originate from the lault or in the Polymetal lode-Friendship silicified-zone area. Stream sediments and soll samples taken near the Friendship silicified zone on South Arm show allomalous amounts of copper, yttrium, and blsmuth. Samples of residual soil drajning the Polymetal lode (locality 22, pl. 1) on the west shore of South Arm are highly anomalous in lead, zinc, and silver. Threshold values for copper also were detected. On the east side of South Arm, the silicified zone is anomalous in zinc and ytcrium. Farther east, beyond the area of geological mapping, stream sediments anc conspiclously anomalous in beryllium and accompanied by threshold zinc values. The beryllium anomalles probably indicate an intrusion east of the map area. Joe Walper (pers, comm.) has found zirconium mineralization in dikes on Dora Bay, just east of South Arm. The mineral he discovered is eudlalyte, a zirconium silicate, confirmed by geochemist N.C. Veach of the DGGS Laboratory.

Geochemical stream-sediment samples from streams draining the east slope of the Moonshine lead-zinc-silver deposit on South Arm (pl. 1) produced only background amounts of metals. Nearby silicified zones yield thresh. old values of zinc, yttrium, and vanadium.

The East Kinger fault zone on South Arm may be responsible for a line of antimony anomalies and thresh. old copper values on both sides of the East Finger fault. These anomalies extend from sample locations 406 to 447 (pl. 2), a distance of $7 \mathrm{~km}$.

Creeks near Klakas Intet contain scattered thresholdto-anomalous copper, zinc, cobalt, manganese, tin, and tungsten values. Along Klakas Inlet west of Max Cove is a serjes of high zinc and threshold chromium, nickel, and antimony values that may be associated with a group of small porphyritic diorite (Kdip) plutons. The large creek dralning into Max Cove from the north has a line of threshold anc and anomalous antimony values, and the large Silurian(?) granodiorite (Sgd) stock there may have a mineral potential.

Threshold-to-anomalous zinc, zirconium, and rareearthelement values show up in the stream sediments along the entire east side of Kassa Inlet. However, the rare earth anomalies may mirror the bedrock composition of the Devonian(?) andesite (Dand) there and have no economic value.

\section{MINERAL DEPOSITS}

\section{INTRODUCTION}

Known mineral deposits in the Craig A-2 quadrangle and vicinity occur in metasomatic skarns, as massive sulfide lenses in Wales Group schists, as dolomitic replacements, and in fractures that clearly cut the bedded rocks. Most of the sulfide accurrences are hosted in the Wales Group. Table 5 is a summary listing of the known mineral deposits, which have been shown on plate 1.

Although the skarn-derived deposits and stratiform mineral occurrences along Hetia Inlet are obviously of different origin, both are very similar in metallic content (table 5). They include major copper and zinc with lesser but significant amounts of molyb. denum, gold, silver, cadmium, antimony, and barium. Lead is conspicuously minor or absent. The stratiform mineralization at Lime Point, Keete, Copper City, and Corbin (localities 19,20,18, and 12, respectively) lie in the same approximate stratigraphic position in the Wales Group (pl. 1), which contains up to 15 percent melakeralophyre (WkL) and related flow rock interbedded in green tuffaceous schist (Wg). Included in this rock package are several lense-shaped pyritic-quartz-sertcite zones probably related to the known massive-sulfide deposits. Similar deposits occur within the Wales Group outside the study area at Khyham, Trocadero Bay, McLeod Bay, and Niblack Anchorage, all on Prince of Wales Island (Hawley, 1976; Herreid, 1964; Peek, 1975).

The Copper Mountain pluton, with its associated skarn-sulfide deposits, intrudes the same approximate stratigraphic sequence as the sections at Corbin, Copper City, and Lime Point. 'Thus, the metals in these skam deposits may have been derived from the leaching of the metalliferous upper(?) section of the Wales Group.

The metallic content of mineyal deposits along the South Arm of Cholmondeley Sound differs somewhat from those along Hetta Inlet to the west. They are high in lead, zinc, and silver and low in copper, molybdenum, and gold (table 5). Anomalous yttrium and bismuth occur in vein deposits. The Polymetal lode appears to be a stratiform deposit, whereas the Moonshine (locality 24), Friendship (locality 23), and associated deposits are structurally controlled veins that clearly crosscut follation in the schist.

The stratigraphy and mineral deposits of the West Shasta mining district in northern California were compared with the Wales Group rocks and mineral deposits. Both areas are floored by volcanogenic-sedimentary piles. Geologic character of the stratiform deposits in both districts is similar (Kinkel and others, 1956), and both appear to have significant amounts of sodic volcanism associated with mineralization. However, the known deposits of the West Shasta district are larger than those of the Wales Group, and Wales Group volcanism is pre-Middle Ordovician and likely Precambrian (Churkin and Eber)ein, 1977); the Balaklala 
rhyolite and associated rocks are considered Devonian (Kinkel and others, 1956).

\section{DOLOMITE DEPOSITS (D)}

Dolomite of several ages is common in the study area. The oldest dolomite occurrences are boudined lenses in Waies Group marble that are considered of primary oxigin. Veins and replacements along faults in the Wales Group at Kassa Inlet are associated with late minor folds. Veins and replacements in the Wales Group green schist at Nutkwa In]et are along steep faults and are related to mafic dikes. Dolomite veins in steep faults cut the marble of the Big River thrust sheel. Late dolomite-bearing veins occur at the Friendship silicified zone and the Moonshine lead-zinc-silver-copper deposit. At the Green Monster Mouniain prospect, a metasomatic dolomite deposit is associated with copper mineralization. In other localitjes dolomite and copper mineraliza. tion are associated along fault zones in the Wales Group. Dolomite deposits are conspicuously absent in the Descon Formation. Mast of the dolomite in the map area, whether of primary or secondary origin, is found in the Wales Group.

Some dolomite-bearing veins contain sulfide mineralization. Dolonite-quartz veins on Kassa Inlet contain pyrite and slightly anomalous values of lead, silver, and gold (sample 549, pl. 2). A dolomite-quartz vein (sample 588 , pl. 2) intruding the lower part of the Devonian bedded rocks on the west shore of Klakas inlet contains minor malachite stajn and background values of copper. lead, zinc, and silver. For $30 \mathrm{~m}$ on the west shore of Hetta Inlet, opposite Jumbo Island, three cross faults with slickensides have veins and replacements of dolomite accompanied will minor malachite stain. There is no mineralization along the fault itself; the copper carbonate is in the wall rock.

\section{QUARTZ BOUDINS AND SILICIFIED ZONES}

Quartz boudins and silicified or siliceous zolses (where inappable, showll as Wss) are fairly conmon in Wales Group rocks. Types of occurrences are 1) silicification of schist, 2) folded quartz that parallels foliation. 3) colded quartz that crossculs foliation, 4) isolated quartz lenses in fold linges, 5 ) uncolded veins extending (rom faults, 6) tabular veins in faults and joints, and 7) suffide-bearing veins in fractures.

Tabular quartz boudins more than $20 \mathrm{~cm}$ thick are uncommon in the Wales Group and Descon Forination schists and phyllites; when present they are commonly folded. The character of the quartz boudins throughout the area suggests that most of the quartz was emplaced before or during regional dynamollermal metamorphism and was probably 'sweated' out of the country rock. Tabular quartz veins less thyn $10 \mathrm{~cm}$ thick are tairly common. The quartz is believed to be deformed by gliding along the foliation planes (figs. 31, 32).
Some quartz bodies display little or no deformation, and many of the undeformed veinlets are obviously late.

Distinctive zones of silicification scattered in layers spaced up to $100 \mathrm{~m}$ apart throughout the Wales Group display no quartz boudins. Evidently, some of these 'silicified' zones must have been siliceous rock layers before metamorphism.

Only a few widely scattered quartz veins and boudins are present in the unfoliated Descon Formation(?) and Devonian rocks on Klakas, Kassa, and Keete Inlets, but $2 \mathrm{~km}$ east of Klakas Lake a large area of Descon Formation(?) mudstone (Odm) has been slightly sheared and a significant amount of unmineralized white-quartz string. ers occurs throughout the rock.

Quartz in the Copper City, Corbin and Polymetal massive sulfide deposits appears to be older than the last phase of regional metamorphism, which ended in Late Ordovician time. Axes of braids in the quartz veins are parallel to kink bands, which deflect earlier crenula. tions. Crosscutting quartz veinlets near the Copper City mineral deposit are deformed (p. 42). Postkinematic sulfide-quartz vein mineralization occurs north of West Arm, occurs as vein deposits on South Arm, and intrudes hornfels (Kh) around the periphery of the Copper Mountain pluton.

Several interesting pyrite-quartz-sericite zones within the quartz sericite schist (Ws) unit occur in the Wales

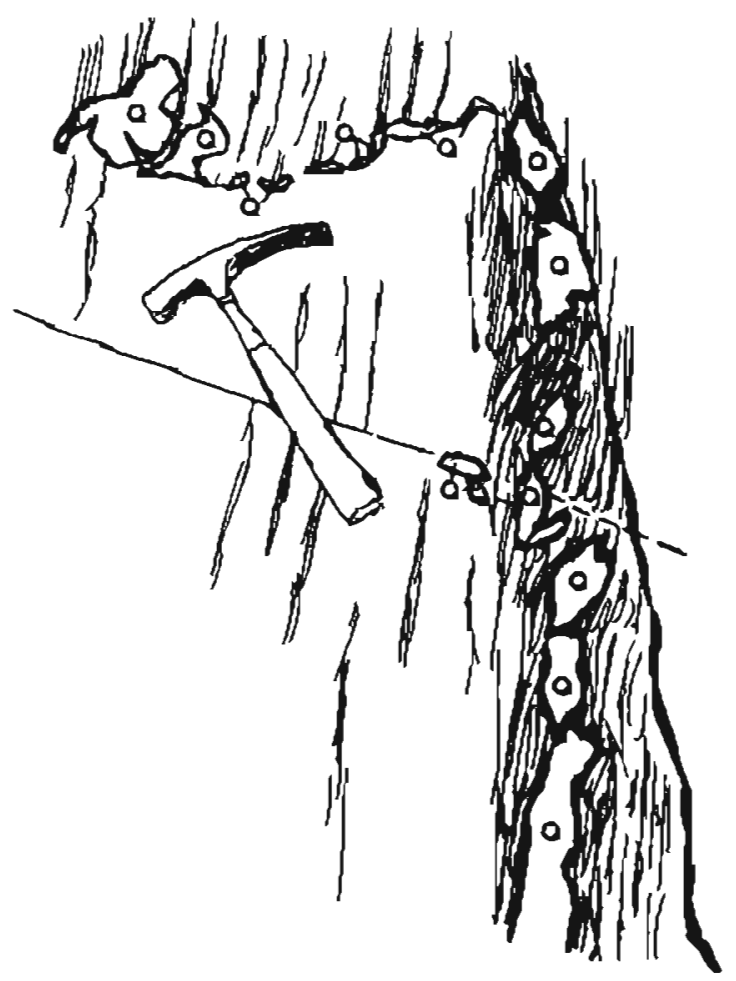

Figure 31. Parsllel and crosscutting quartz deformed by gliding along foliation planes, South Arm, Cholnuondeley Sound. 
Table 5. Summary listing of known mineral occurrences in the Craig A-2 quadrangle and vicinity.

\begin{tabular}{|c|c|c|c|c|c|}
\hline Occurrence & Name & Production record & Type of deposit & Major metals & Minor metals \\
\hline 1 & $\begin{array}{l}\text { Gould Island } \\
\text { prospect }\end{array}$ & None recorded & $\begin{array}{l}\text { Quartz vejn in skarn } \\
\text { zone north of Copper } \\
\text { Mountain Inlet. }\end{array}$ & $\begin{array}{l}\mathrm{Pb}-\mathrm{Zn} \cdot \mathrm{Ag}, \\
\mathrm{Cu}\end{array}$ & Mo \\
\hline $2^{1}$ & $\begin{array}{l}\text { Sultana Group } \\
\text { (Wright, 1915) }\end{array}$ & None recorded & $\begin{array}{l}\text { Skarn pods containing } \\
\text { chalcopyrite-epidote- } \\
\text { quartz veins in diorite } \\
\text { pluton. }\end{array}$ & $\mathrm{Cu}-\mathrm{Fe}$ & $\mathrm{Ni}(?)$ \\
\hline 3 & $\begin{array}{l}\text { Houghton or } \\
\text { Cuprite Copper } \\
\text { Company } \\
\text { (Wright, 1915) }\end{array}$ & $\begin{array}{l}\text { Small tonnages } \\
\text { of 'high grade' } \\
\text { shipped during } \\
1906-11 \text { (Bur. } \\
\text { vers, 1967) }\end{array}$ & $\begin{array}{l}\text { Chalcopyrite-magnetite } \\
\text { garnet-epidote-sphale- } \\
\text { rite-marcasite skarn } \\
\text { deposit. }\end{array}$ & $\mathrm{Cu} \cdot \mathrm{Zn} \cdot \mathrm{Ag}$ & $\mathrm{Pb}-\mathrm{Cd}$ \\
\hline 4 & Billie Mtn. & None recorded & $\begin{array}{l}\text { Epidote-garnet-sulfide } \\
\text { skarn. }\end{array}$ & $\mathrm{Cu}-\mathrm{Zn}_{\mathrm{n}}$ & $A g \cdot N b-S n-W$ \\
\hline 5 & $\begin{array}{l}\text { Campbell } \\
\text { prospect }\end{array}$ & None recorded & $\begin{array}{l}\text { Chalcopyrite-pyrrhotite } \\
\text { garnet skarn deposit. }\end{array}$ & $\mathrm{Cn} \cdot \mathrm{Zn} \cdot \mathrm{Fe}$ & $\mathrm{Pb} \cdot \mathrm{Ag}$ \\
\hline 6 & $\begin{array}{l}\text { Mt. Jumbo } \\
\text { prospect }\end{array}$ & None recorded & $\begin{array}{l}\text { Chalcopyrite-pyrite- } \\
\text { garnet epidote skern } \\
\text { deposic. }\end{array}$ & $\begin{array}{l}\mathrm{Cu} \cdot \mathrm{Zn} \cdot \mathrm{Ag}, \\
\mathrm{Fe}\end{array}$ & $\mathrm{Pb}$ \\
\hline 7 & $\begin{array}{l}\text { Magnelite Clift } \\
\text { deposit }\end{array}$ & $\begin{array}{l}\text { Small tonnages } \\
\text { of 'high-grade' ore } \\
\text { added to Jumbo } \\
\text { production. }\end{array}$ & $\begin{array}{l}\text { Chalcopyrite-epidote } \\
\text { garnet skarn deposit. }\end{array}$ & $\mathrm{Fe}$ & $\mathrm{Cu}-\mathrm{Ni}(?)$ \\
\hline 8 & $\begin{array}{l}\text { Upper mag- } \\
\text { netite bodies }\end{array}$ & None recorded & $\begin{array}{l}\text { Magnetite-chalcopyrite } \\
\text { epidote skarn pods. }\end{array}$ & $\mathrm{Fe}-\mathrm{Cu}$ & $Z n-A g-A u$ \\
\hline 9 & Gonasson & None recorded & $\begin{array}{l}\text { Magnetite-chalcopyrite } \\
\text { epidote-diopside-garnet } \\
\text { skarn. }\end{array}$ & $\mathrm{Fe} \cdot \mathrm{Cu}$ & $\mathrm{Zn}-\mathrm{Ag} \cdot \mathrm{Au}$ \\
\hline 10 & $\begin{array}{l}\text { Jumbo deposits } \\
\text { (Wright, 1925; } \\
\text { Kennedy, 1953) }\end{array}$ & $\begin{array}{l}10,197,264 \mathrm{lb} \\
\text { copper, } 87,778 \\
\text { oz silver, } 7,076 \\
\text { oz gold from } \\
122,937 \text { T ore }\end{array}$ & $\begin{array}{l}\text { Chalcopyrite-pyrrhotite- } \\
\text { pyrite molybdenite- } \\
\text { sphalerite-epidote- } \\
\text { diopside-garnet skarn } \\
\text { deposits. }\end{array}$ & $\begin{array}{l}\mathrm{Cu} \cdot \mathrm{Zn} \cdot \mathrm{Ag}- \\
\mathrm{Zn} \cdot \mathrm{Mo}\end{array}$ & $\mathrm{Pb}$ \\
\hline $11 \mathrm{a}-\mathrm{c}$ & $\begin{array}{l}\text { Copper Moun- } \\
\text { tain deposits }\end{array}$ & $\begin{array}{l}5,768 \text { tons 'high- } \\
\text { grade' ore smelted } \\
\text { at Copper Harbor } \\
\text { (Wolfs and Heiner, } \\
1971 \text { ) }\end{array}$ & $\begin{array}{l}\text { Malachite-azurite. } \\
\text { chalcopyrite-epidole } \\
\text { sphalerite-garnet } \\
\text { skarn(?) deposits. }\end{array}$ & $\begin{array}{l}\mathrm{Cu}-\mathrm{Zn}_{\mathrm{n}} \mathrm{Ag}- \\
\mathrm{Au}\end{array}$ & Sb-Co-Mo \\
\hline 12 & $\begin{array}{l}\text { Corbin (Alaska } \\
\text { Metals Mining } \\
\text { Co.) (Wright, } \\
\text { 1915) }\end{array}$ & $\begin{array}{l}\text { Limiled tonnage } \\
\text { of massive-sul- } \\
\text { fide ore shipped } \\
\text { to Tacoma } \\
\text { 1906-1913 }\end{array}$ & $\begin{array}{l}\text { Pyrite-chalcopyrike } \\
\text { sphalerite massive } \\
\text { sulfide lense in } \\
\text { Wales Group green } \\
\text { schist. }\end{array}$ & $\begin{array}{l}\mathrm{Cu}-\mathrm{Zn}-\mathrm{Ag}- \\
\mathrm{Au}\end{array}$ & Mo \\
\hline $19 a, b$ & $\begin{array}{l}\text { Green Monster } \\
\text { deposits }\end{array}$ & $\begin{array}{l}\text { Museum-quality } \\
\text { epidote crystals } \\
\text { mined by Smith- } \\
\text { sonian Institute } \\
\text { and other } \\
\text { lessees } 1930 \text {. } \\
\text { present (Eskil. } \\
\text { Anderson, pers. } \\
\text { comm.). }\end{array}$ & $\begin{array}{l}\text { Epidote quartz vugs } \\
\text { in slcarn zone, mag- } \\
\text { netile-actinolite- } \\
\text { dolomile-limonite } \\
\text { skarn deposit. }\end{array}$ & $\mathrm{Fe}-\mathrm{Cu}$ & $\mathrm{Zn} \cdot \mathrm{Ag} \cdot \mathrm{Sc}$ \\
\hline 14 & $\begin{array}{l}\text { Summit Lake } \\
\text { A }\end{array}$ & None recorded & $\begin{array}{l}\text { Chaicopyrite-sphale. } \\
\text { rite covellite, epidote- } \\
\text { garnet-quartz skarn. }\end{array}$ & $\mathrm{Cu}-\mathrm{Ag}-\mathrm{Fe}$ & $7 n$ \\
\hline 15 & $\begin{array}{l}\text { Summit Lake } \\
\mathrm{B}\end{array}$ & $\begin{array}{l}\text { None recorded; } \\
\text { several tons of } \\
\text { 'high grade" } \\
\text { sacked and } \\
\text { stockpiled. }\end{array}$ & $\begin{array}{l}\text { Magnetite-chalcopyrite } \\
\text { epidote-garnet diopside } \\
\text { skarn. }\end{array}$ & Nol assayed & Not assiyed \\
\hline
\end{tabular}


Table 5. (Cont.)

\begin{tabular}{|c|c|c|c|c|c|}
\hline Occurrence & Name & Production record & Type of deposit & Major metals & Minor metals \\
\hline 16 & $\begin{array}{l}\text { Lake Marge } \\
\text { mineralized } \\
\text { zone }\end{array}$ & $\begin{array}{l}\text { None recorded, } \\
\text { no prospects. }\end{array}$ & $\begin{array}{l}\text { Disseminated molyb- } \\
\text { denite, chalcopyrite in } \\
\text { epiriote-garnet stearn. }\end{array}$ & $\mathrm{Cu} \cdot \mathrm{Zn} \cdot \mathrm{Mo}$ & $\mathrm{Pb} \cdot \mathrm{W}$ \\
\hline $17 \mathrm{a}, \mathrm{c}$ & Hetta Mountain & None recorded & $\begin{array}{l}\text { Chalcopyrite-sphalerite } \\
\text { limonite-diopside gar- } \\
\text { net quartz skarn. }\end{array}$ & $\mathrm{Cu} \cdot \mathrm{Zn}$ & $\begin{array}{l}\text { Mo-Ag-Au-Co- } \\
\mathrm{Cd}\end{array}$ \\
\hline 18 & $\begin{array}{l}\text { Deer Bay } \\
\text { occurrence }\end{array}$ & $\cdots$ & $\begin{array}{l}\text { Pyrite-sericite quartz } \\
\text { lenses in Wales Group } \\
\text { green schist. }\end{array}$ & $\cdots$ & $\mathrm{Pb}-\mathrm{Nb}-\mathrm{Au}$ \\
\hline 19 & $\begin{array}{l}\text { Simmons Pt. } \\
\text { Wright Creek } \\
\text { zone }\end{array}$ & $\cdots$ & $\begin{array}{l}\text { Pyrite-sericite quartz } \\
\text { sulfide lense in Wales } \\
\text { Group. }\end{array}$ & Not assayed & Not assayed \\
\hline 20 & Copper City & $\begin{array}{l}1600 \text { tons of } \\
\text { ore shipped to } \\
\text { smelter by } 1903- \\
05 \text { believed to be } \\
\text { typical of pro- } \\
\text { duction during } \\
8 \text { years of } \\
\text { operation (Buf. } \\
\text { vers, 1967) }\end{array}$ & $\begin{array}{l}\text { Chalcopyrite-pyrite- } \\
\text { sphalerite, massive } \\
\text { sulflde lense in Wales } \\
\text { Group. }\end{array}$ & $\begin{array}{l}\mathrm{Cu}-\mathrm{Zn}-\mathrm{Ag}- \\
\mathrm{Au}\end{array}$ & $\mathrm{Mo}-\mathrm{Ba}-\mathrm{Pb}-\mathrm{Sb}$ \\
\hline 21 & $\begin{array}{l}\text { Lime Point } \\
\text { barite }\end{array}$ & $\begin{array}{l}\text { Test shlpment } \\
\text { made, no major } \\
\text { production } \\
\text { (Wright, 1915i } \\
\text { Buddington and } \\
\text { Chapin, 1929). }\end{array}$ & $\begin{array}{l}\text { Barite lenses in Wales } \\
\text { Group marble; some } \\
\text { dolomitization along } \\
\text { faults. }\end{array}$ & Not assayed & Not assayed \\
\hline 22 & $\begin{array}{l}\text { Kecte Inlet } \\
\text { prospect }\end{array}$ & None recorded & $\begin{array}{l}\text { Chalcopyrite-pyrite } \\
\text { massive sulfide lense } \\
\text { in siliceous schist } \\
\text { (Chapin, 1916). }\end{array}$ & $\mathrm{Cu} \cdot \mathrm{Zn}_{\mathrm{n}}$ & $\cdots$ \\
\hline 23 & Nutkwa Inlet & $\begin{array}{l}50 \mathrm{oz} \text { gold, } \\
36 \mathrm{lb} \text { lead }\end{array}$ & $\begin{array}{l}\text { Discontinuous quartz vein } \\
\text { system in greenstone } \\
\text { schist (Rohm, 1939). }\end{array}$ & $\mathrm{Au}-\mathrm{Ag} \cdot \mathrm{Pb}$ & $\cdots$ \\
\hline 24 & Polymetal & $\begin{array}{l}\text { Not known: } \\
\text { considerable } \\
\text { development } \\
\text { work to } 1908 .\end{array}$ & $\begin{array}{l}\text { Sphalerite-galena } \\
\text { massive sulfide de- } \\
\text { posit. }\end{array}$ & $\mathrm{Pb}-\mathrm{Zn}$ & $\mathrm{Ag} \cdot \mathrm{Au}$ \\
\hline 25 & Friendship & None & $\begin{array}{l}\text { Disseminated chal- } \\
\text { copyrite in quartz- } \\
\text { carbonate vein in- } \\
\text { truding Wales Group. }\end{array}$ & $\mathrm{Cu}$ & $\mathrm{Y} \cdot \mathrm{Bi}$ \\
\hline 26 & Moonshine & $\begin{array}{l}\text { Limited ton- } \\
\text { nage of 'high- } \\
\text { grade' sacked } \\
\text { and shipped } \\
\text { (Bufvers, } \\
\text { 1967). }\end{array}$ & $\begin{array}{l}\text { Sphalerite-galena } \\
\text { siderite-quartz carbonate } \\
\text { vein system intrudes Ws. }\end{array}$ & $\mathrm{Pb}-\mathrm{Zn}-\mathrm{Ag}$ & $\mathrm{Cu}-\mathrm{Cd} \cdot \mathrm{Sb}$ \\
\hline 27 & Klakas Lake ${ }^{1}$ & None & $\begin{array}{l}\text { Chalcopyrite-quartz } \\
\text { carbonate vein. }\end{array}$ & $\mathrm{Cu}$ & $\cdots$ \\
\hline
\end{tabular}

\footnotetext{
${ }^{b}$ Nat deseribed In this report
} 
Group along Hetta Inlet. They form yellowish-brown outcrops along the beach, and consist of Wales Group tuffaceous schist (Wg) interbedded with metakerato. phyre tulf (Wk). These lensoid pyritic zones contain 2. to 10-percent irregular, parallel, and crosscutting quartz veinlets with erratic orientation and some quartz 'knots' more than $20 \mathrm{~cm}$ in diameter. Emission spectrographic analyses of a chip sample of a pyritic-quartzsericite zone south of Deer Bay (locality 18, pl. 1) show $20 \mathrm{ppm}$ gold and $90 \mathrm{ppm}$ lead. This is probabiy not an accurate analysis of the zone, but it indicates that more work is warranted on this zone and others like it. Zones such as these have been earlier noled at Niblack Anchorage, particularly the Dama prospect, and shown to be assoclated with the pyrite-chalcopyrite mineralization there (Herreid, 1964). Peek (1975) suggested that the zones al Niblack Anchorage are metarhyolitic tuff.

\section{JUMBO MINE}

The Jumbo mine (locality 10, pl. 1) is located on the steep headwall of a glacial cirque calsed the Jumbo Basin, on the western slopes of the ridge between Coppey Mountain and Mount Jumbo. Development on the deposit, discovered by Aaron Shellhouse in 1897, was begun in 1902 by the Alaska Industrial Company. The tram from the beach to the adit at $1,700 \mathrm{ft}$ (fig. 33) was completed in 1906 and ore was first shjpped in 1907 to the Tyee Smeiter in British Columbia (Wright, 1915, p. 56-61). According to Bufvers (1967, p. 19) "the

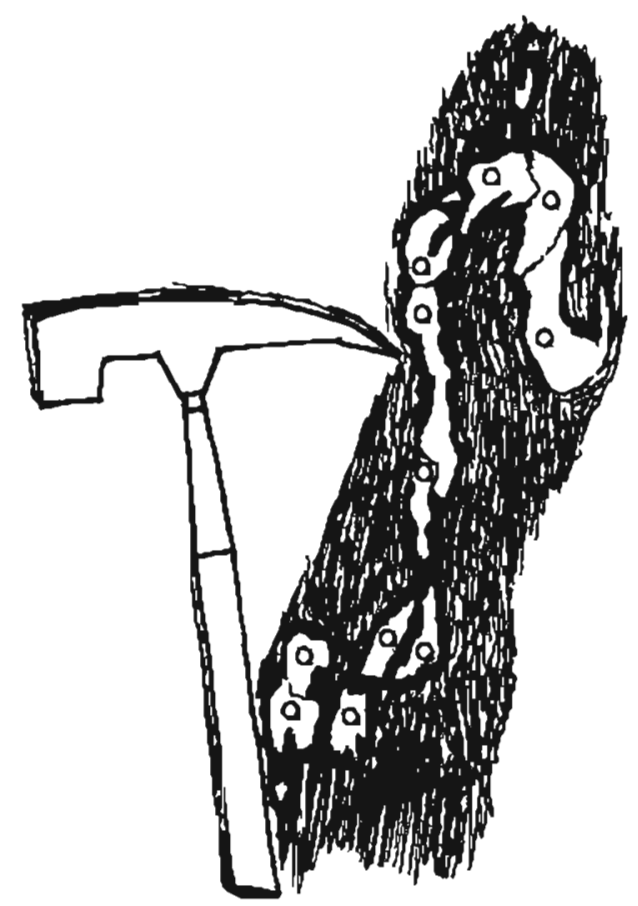

Figure 32. Folded quartz masses cutting foliation in Friendship silicified zone, Cholmondeley Sound. The quartz has been segregated into lumps by plastic flow. largest ore body and also the best grade of ore was on the No. 4 claim where an irregular body of chalcopyrite ore, 30 to 40 feet wide, 120 feet long and about 140 peet deep, supplied ore during the first years." The last year of regular production was in 1918, but several thousand tons were mined in 1923 (Bufvers, 1967). At present no buildings are standing (fig. 34 ), but the tram. line cut is still visible and the rusting cables can be followed from the beach to the adit at the 1,570-ft elevation. The upper workings, located in resistant skarn bedrock, are still open.

Total production according to Kennedy (1953, p. 4) was $10,194,264 \mathrm{lb}$ of copper, 7,076 o7 of gold, and 87,778 oz of silver won from 122,937 tons of ore.

The ore deposits of the Jumbo Mine are in skams derived from igneous rock and marble roof pendants along the west side of the Copper Mountain pluton (pl. 1). The ore contains irregular pyrhotite-chalcopysite-pyrite-sphalerite-molybdenite-epidote-garnet-diopside-quartz-calcite ore bodies that are small by modern standards. Ore occurs in both intrusive- and carbonatederived skarns (although the latter predominates). Fracturing has played an Important role in the localization of the ore. Kennedy (1953, p. 31) points out:

".afractures in the host rocks have been the loci of wall rock alteration and are filled with skarn minerals. The copper deposits fill fractures which extend into the marble adjacent to the skarn zone, and many late fractures cutting the skarn zone contain chalcopyrite."

In one area a contact-metamorphosed mafic dike was mined for copper. The richest ore on the No. 4 claim was mined from a small glory hole or open pit whose rim is at an elevation of about $1,800 \mathrm{ft}$. Both Kennedy (1953) and Bufvers (1967) stated that the ore zone probably extends below the present workings. High-grade copper mineralization has been reported at the bottom of a shaft at the 1,570-it workings, but the shatt is now flooded (Kennedy, 1953). At this level there are four ore shoots that make a total of 300 tons per vertical meter (Hogg, 1965).

The Jumbo deposits are famous for their epidote crystals. According to Kensiedy (1953, p. 24):

\footnotetext{
"Locally epidote is an abundant mineral in the skarn zone at the Jumbo Mine. It occurs as medium-sized irsegular grains replacing garnet, in groups of radiating crystals surrounded by Iater quartz and calcite, and as coarse crystals of exceptional beauty and complexity of crystal form lining the walis of vugs. The epidote specimens from the Jumbo area are rivaled only by those on the Tyrol."
}

The vugs, in many cases, are hy drothermal pockets in skam, like those at Green Monster Mountain, with 


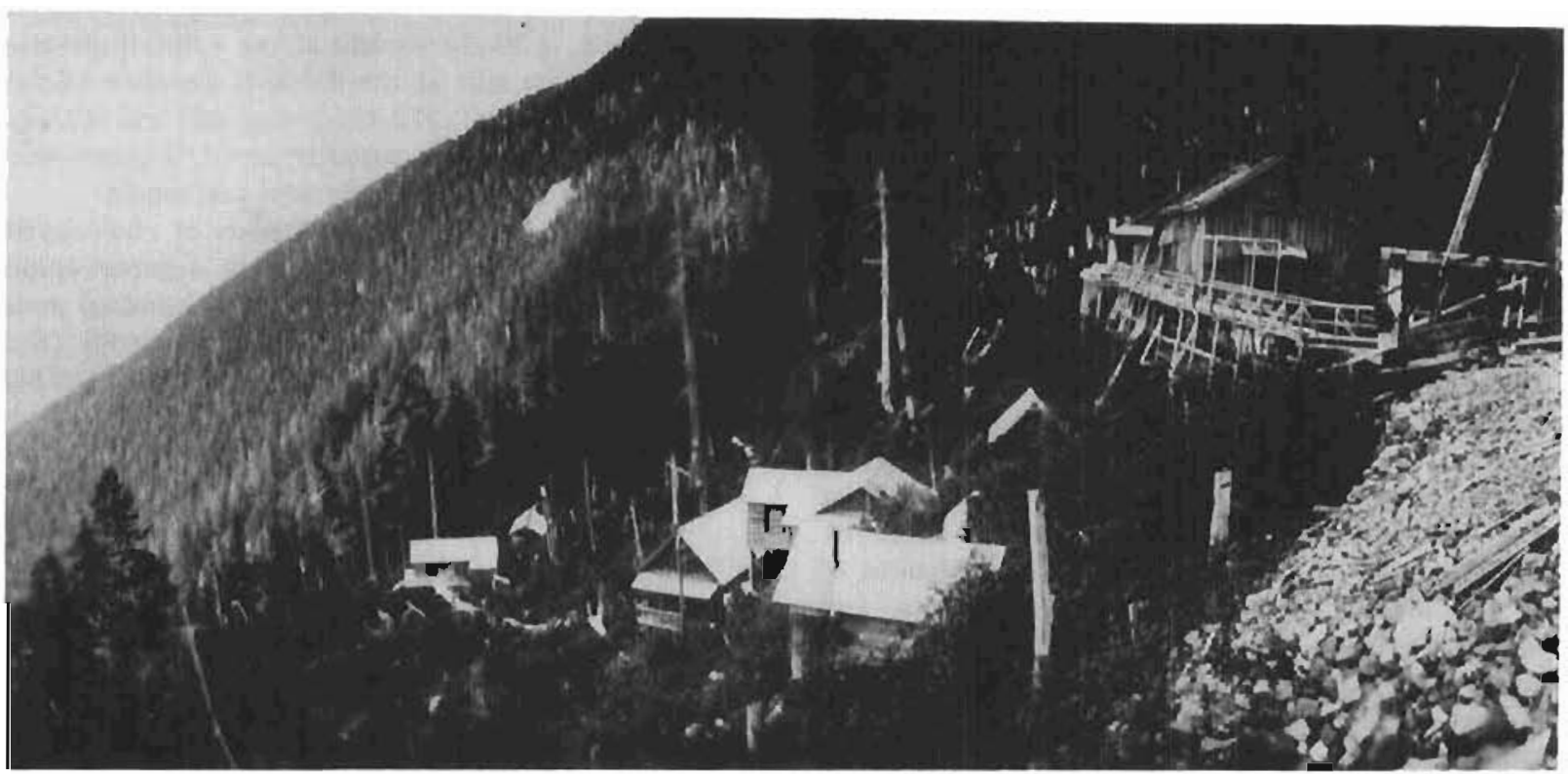

Figure 33. Upper comp, Jumbo inine, 1913. (Photo courtesy University of Alaska archives.)

epidote crystals in a dayk matrix of 'decomposed' minerals. According to Leavens (1967), the epldote mineralization is never more than "a few reet" from small basaltic dikes; he feels they are the source of the al teralion solulions.

\section{MAGNETITE CLIFF DEPOSIT}

Several impressive shows of mineralization an: present in Jumbo Basin north of the Jumbo deposit. The largest is the Magnetite Cliff deposit (locality 7, ol. 1). a thin 25-m-thick shell of magnetite tlut mantles the granodiorite that is in contact with skarn and nearly parallel to the hill slope. It forms a remarkable clift exposure visible from Hetla Inlet. There are four short adits into this zone.

According to Kennedy (1953, p. 38-39), the magnetite mineralization has replaced garnet-diopside skam, which was derived from marble; the skarn uniformly contains 2 to 3 percent clialcopyrite, and above the 1,400-ft elevation, 370,000 tons of mineralization grad. ing 46 percent iron and 0.77 percent copper has been proven by exploration.

The Magnetile Cliff deposit may extend to significant depths along the igneous contact, as abandoned diamond-drilling stations on the slope south of the deposit attest.

\section{UPPER MAGNETITE BODIES}

On the ridge about $1 \mathrm{~km}$ northeast of Nagnetice Cliff are five small magnetite deposits: Cour occur in roof pendants of skarn and marble and one is found in granodiorile-derived skarn (locality 8, pl. 1). Kennedy'
(1953, p. 40) estimated reserves of these deposits as about 50,000 tons of mineralization, wits about the same iron and copper content as the Magnetite Cliff deposit.

\section{GONNASON DEPOSIT}

About $600 \mathrm{~m}$ northwest of the Jumbo 'glory hole' is a large body of magnetite-chalcopyrite-skarn mineralizatlon, lirst found by A.G. Jones and W. Gommason of the Hasna Mining Company in the 1960s. The deposit (locality 9, pl, 1) sporadically crops out through thick timber and is estimated to be an equant lense, 50 by 75 $m$ on the surface with an unknown thickness (but believed to be less than half of its lengthi).

A channel sample taken down the dip slope of the deposit averaged 50.6 percent iton and 0.94 percent copper along a 25-m-long sample line (Hogg, 1965). According to Harna Mining geologists, the deposit is comparable in size and grade to the Magnetite Cliff deposit.

\section{COPPER MOUNTAIN DEPOSITS}

The Alaska Copper Company mines are on the south slope of Copper Mountain (fig. 34, localities 11a-c, pl. 1). The workings are near the Copper Mountain ridgetop at 3,200- to $3,600-\mathrm{ft}$ elevations, but showings extend down to at least $2,200 \mathrm{cl}$. The deposit was discovered in 1897 by Charjes Reynolds and Thomas Wright. Five hundred tons of ore worth about $\$ 18,000$ was shipped in 1902, and by 1905, a 250-ton/day Allis-Chalmers smelter had been constructed at the base of the aerial tram on Copper Harbor. Between 1903 and 1906, 
224,285 ib of copper, 10,331 oz of silver and 145 oz of gold were won from 5,768 tons of ore (Wolff and Heiner, 1971). By 1907, 1,200 m of tunnels, $145 \mathrm{~m}$ of shafts and ralses, and numerous pits had been completed (Wright, 1915, p. 57). This work showed that the conspicious showings of rich copper carbonate ore along the ridge falled to extend down to the adit at the 2,350-ft elevation. Work was halted in 1907 and resumed in 1914, but fajled to produce additional ore (Bufvers, 1967, p. 21).

The relation of skam mineralization to geology in the Copper Mountain district is evident along the southwest ridge of Copper Mountain (pl. 1). The 200-mthick tongue of granodiorite (plagiodase An-20) that crosses the ridge is partly transformed by skarn by alteration of hornblende to diopside and additions of veins and masses of epidote, garnet, magnetite, and scapolite. Along the southwest side of the granodiorite tongue this replacement is stronger and the rock is skam with relicl patches of granodiorite (plagioclase An-30). The skarn contains scattered showings of chalcopyrite and discontinuous pods of copper carbonate. These small high-grade deposits were the richest on the property and most of the mining and development consisted of 'pockel mining' along this contact.

The northeasl side of the granodiorite tongue is bordered by coarsely crystallized skarn. Here highly fractured marble was replaced and veined by quartz, garnet, epidote, speculerite, geothite, chalcopyrite, and pyrite, commonly with euhedral cryslals. Low.grade copper mineralization is present sporadically along the contact of this skarn with dark hornfels. Small open cuts and shorts adits are present, but little commercial. grade mineralization was found.

\section{HOUGHTON PROSPECT}

The Houghton prospecl (locality $3, \mathrm{pl} .1$ ), on the norlbwesl side of the Copper Mountain pluton, was

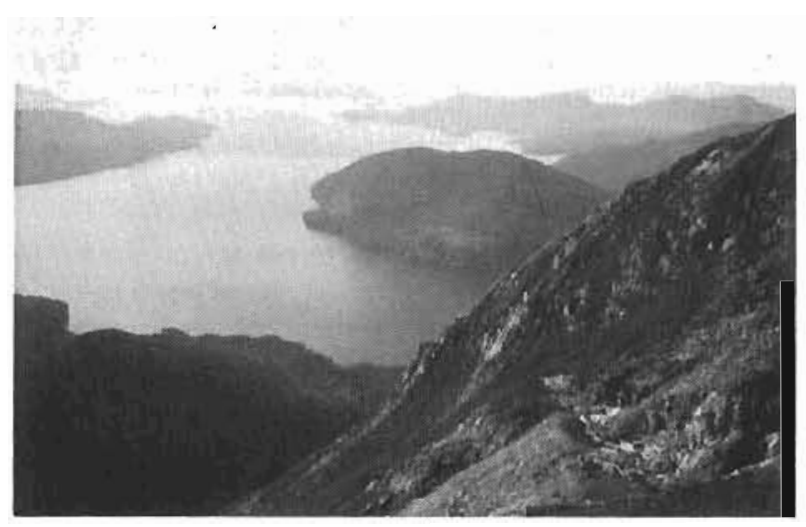

Figure 34. Alaska Copper Company open cut, southwest spur of Copper Mountain. Hetla inlel in background. located in 1901, and by 1908 had a camp, an aerial tram to the beach, a $30 \mathrm{~m} \cdot \mathrm{long}$ adit at the 1,600 - fl elevation, and a $25-\mathrm{m}$-long adit at the 1,700-ft elevation (Wright, 1915, p. 62-63). In 1972 the lower adit was still open but the upper adil was partially caved; a steam-oriven winch and the aerial tram cable were still visible.

The deposit consists of small pods of chalcopyrite, magnetite crystals, and pyrrhotite in a garnel-epidote skarn zone about $8 \mathrm{~m}$ wide and several hundred meters long along the faulted(?) contact of granodionite (Kgdi) and marble $(W m)$. A grab sample (No. 72, pl. 2) of highgrade mineralization from the dump yielded 23.3 per. cent copper, 0.7 percenl zinc, $25 \mathrm{ppm}$ lead, $10.28 \mathrm{oz} / \mathrm{ton}$ sijver, and $0.5 \mathrm{oz} / \mathrm{lon}$ gold.

Evidence for mineralization localized along a fracture zone was abserved both in the field and under a microscope. A polished section of the sulfide-bearing skarn contains major chalcopyrite and pyrite with minor sphalerite and siderite(?). It seens to be a breccia with cracks and crevices filled with siderite. Some of tlie chalcopyrite has been altered to covellite.

\section{SMALL SKARN PROSPECTS NEAR 'THE HOUGHTON PROSPECT}

The Camphell prospect (Incality 5, pl. 1) consists of small pyrrhotite-rich pods of mineralizalion exposed in a short adil about $1,200 \mathrm{~m}$ west of the Houghton pros. pect. The 15-m-long adit, localed at the 700 . It elevation, is parlly caved at the portal. The depusil is a marble-derived skarn near the contact of a small grano. diorite plug that is probably an apophysis of the Copper Mountain plutor. A polished section of mineralized rack shows pyrrholite with a little chalcopyrite in a skarn matrix. One sample (No. 78, pl. 2) produced 1.380 ppm copper, 20 ppm lead, 175 ppm zinc, 1.5 ppm silver, and a trace of gold.

The Mount Jumbo prospect (locality 6, pl. L) is at the 1,200-fl elevation, about 600 in soutliwest of the Houghton prospect. A short adit driven into the oxe zone shows irregular pods of massive pyrrholice.rhal. copyrite mineralization in a skatn zone peripheral to another small granodiorite body. A polished section from the deposil reveals major pyrrhotite, pyrite, and chalcopyrite with minor marcasite and geothice. The pyrrhotite is partly replaced by marcasite, and the pyrite forms colloform veins. Chalcopyrite and pyrrho. tite. were probably the first sulfides deposited. A grab sample of the ore yielded 4.2 percent copper, 45 ppin lead, $850 \mathrm{ppm}$ zinc, $3.2 \mathrm{oz} /$ ton silver, but no gold.

A small mineralized zone is present at the 760-it elevation on the north slope of Billie Mountain, op. posite Portage Bay (locality 4, pl, 1). This zone is in a skarn slong the contacl of an epidotized dionte body adjacent to the Copper Mountain pluton. The skarn was derived from marble host rock. A grab sample of material from the zone shows 840 pom copper, 480 ppm 
zinc, $56 \mathrm{ppm}$ lead, and $1.2 \mathrm{oz} /$ ton silver. Several tungsten, silver, and zinc geochemical anomalies have been obtained from rock and stream-sediment samples taken prom this area (pl. 2).

\section{GREEN MONSTER MOUNTAIN PROSPECTS}

The Green Monster Mountain copper and magnetlte showings (localities $13 \mathrm{a}, \mathrm{b}, \mathrm{pl} .1$ ), on the east side of Green Monster Mountain, were discovered in 1900. When C.W. Wright visited in 1908, development work consisted of two 20-m-long tunnels and one pit about $3 \mathrm{~m}$ deep. He described the deposits as massive sulfides in skam, disseminated sulfides in skarn, and sulfide-bearing vein deposits in skarn and hornfels (Wright, 1915 , p. 61-62). There has been some stripping of the area where epidote crystals have been mined but otherwise little appears to have been done since then. Lessees of Eskil Anderson were exploring for pockets of epidote crystals when the authors visited in 1972.

The known skarn and associated sulfide and magnelite deposits are in marble near the southern end of the Green Monster Mountain epidotized diorite body (Keg on $\mathrm{pl}$. 1). The sulfide, magnetite, and crystal deposits were deposited along steep faults shortly after intrusion of the igneous rocks. The epidote crystal area in skarn and the old adit in dolomitized marble are along a steep northeast-trending fault that runs along the northwest side of the epldotized diorite pluton. Movement along this lault took place after igneous in. trusion but before the rocks had cooled, as shown by the offset of the Copper Mountain pluton, granulation of skarn, and growth of skarn minerals in fractures.

The area where the well-known Green Monster epidote crystals have been mined (locality $13 a$, pl. 1) is 110 $m$ southwest of the epidotized diorite body at about the 2,550-ft elevation, an area of much-fractured epidote. garnet-quartz-uralite-pyrite-chalcopyrite skarn. There is no clear-cut dominant direction of shearing. Pockets of unfractured euhedral epidote and quartz up to $100 \mathrm{~m}$

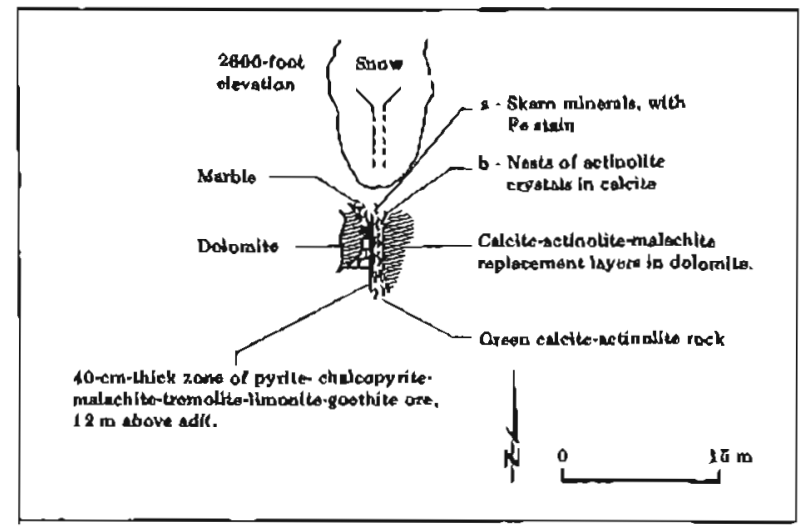

Figure 35. Sketch map of mineral zone, west side of Green Monster Mountain. in diameter are found 'floating' in decomposed 'mud' within vugs in the skarn bedrock. Some epidote crystals were cracked and healed by the growths of tiny quartz crystals, and the crystals apparently grew during fracturing. One old adit at the 2,600-ft elevation, about $100 \mathrm{~m}$ north of the epidote-crystal locality, was driven along a skaxn-sulfide zone, which is possibly fault controlled. The sketch map (fig. 35) shows the association of zones of sulfides, coarsely crystalline skarn minerals, and dolomite.

A skarn zone (locality $13 \mathrm{~b}, \mathrm{pl} .1$ ) about $80 \mathrm{~m}$ wide is located along the southeast side of the epidotized diorite pluton, on the northwest rim of Green Monster Mountain at about $2,900 \mathrm{ft}$. The skarn minerals are monticellite, calcite, and chlorite at the north end and diopside, actinolite, and calcite at the south end. The skarn is right-laterally oflset $15 \mathrm{~m}$ by each of two steep northwest-trending faults. Along one of these faults at the pluton-skarn contact is a small pod of magnetite mineralization. This is the $2.6-\mathrm{m}$-deep $(8-\mathrm{ft})$ prospect pit mentioned by Wright (1915). A 6-m-wide band of discontinuous dolomite of metasomatic origin lies on the marbie side of the skarn. Dolomitization has aiso occurred along a N. $80^{\circ}$ E.-trending, steeply dipping right-lateral fault at the north end of the mapped skarn zone. The skarn may extend farther north but the contact was snow covered when the mapping was done in late July 1972.

Two other copper-magnetite prospects were visited on the north side of Summit lake, about $2,5 \mathrm{~km}$ southeast of the epldote-crystal locallty at about the 1,900. and 1,850-pt elevations. Both are clearly fault controlled. At the Summit Lake 'A' prospect (locality 14, pl, 1; $1 \mathrm{~g}$. 36 ), three small caved adits and an ore dump of sulfidebearing skarn are now overgrown with vegetation. An irregular skarn zone separates hornblende diorite and coarsely crystalline marble bedrock, which is truncated by a fault that trends $\mathrm{N} .70^{\circ} \mathrm{E}$. The fault trace follows a linear saddle on the crest of the hlll. A polished section of the sulfide-bearing skarn shows major chalcopyrite and minor sphalerite in a gangue of guartz. The latest mineral to form is euhderal chalcopyrite grains that contain blades of skarn. An assay was not obtained from this sample, but il undoubtedly has a high copper content:

The Summit Lake 'B' prospect (locality 15, pl. 1), located along a fuulk offset on the diorite-marble contact in a situation similar to the ' $A$ ' prospect, las a pit that contains several tons of magnetite-chalcopyrite mineralization. An assay of a high grade sample (No. 254 , pl. 2) showed 16.0 percent copper, 2.0 percent zinc, $175 \mathrm{ppm}$ lead, and $5.1 \mathrm{oz} /$ ton silver.

\section{GOULD ISLAND PROSPECT}

Near the southwest tip of Gould Island (locality 1 , pl. 1) is a 4-m-wide white quartz vein containing minor pyrite, chalcopyrite, and malachite in a prospect pit; 


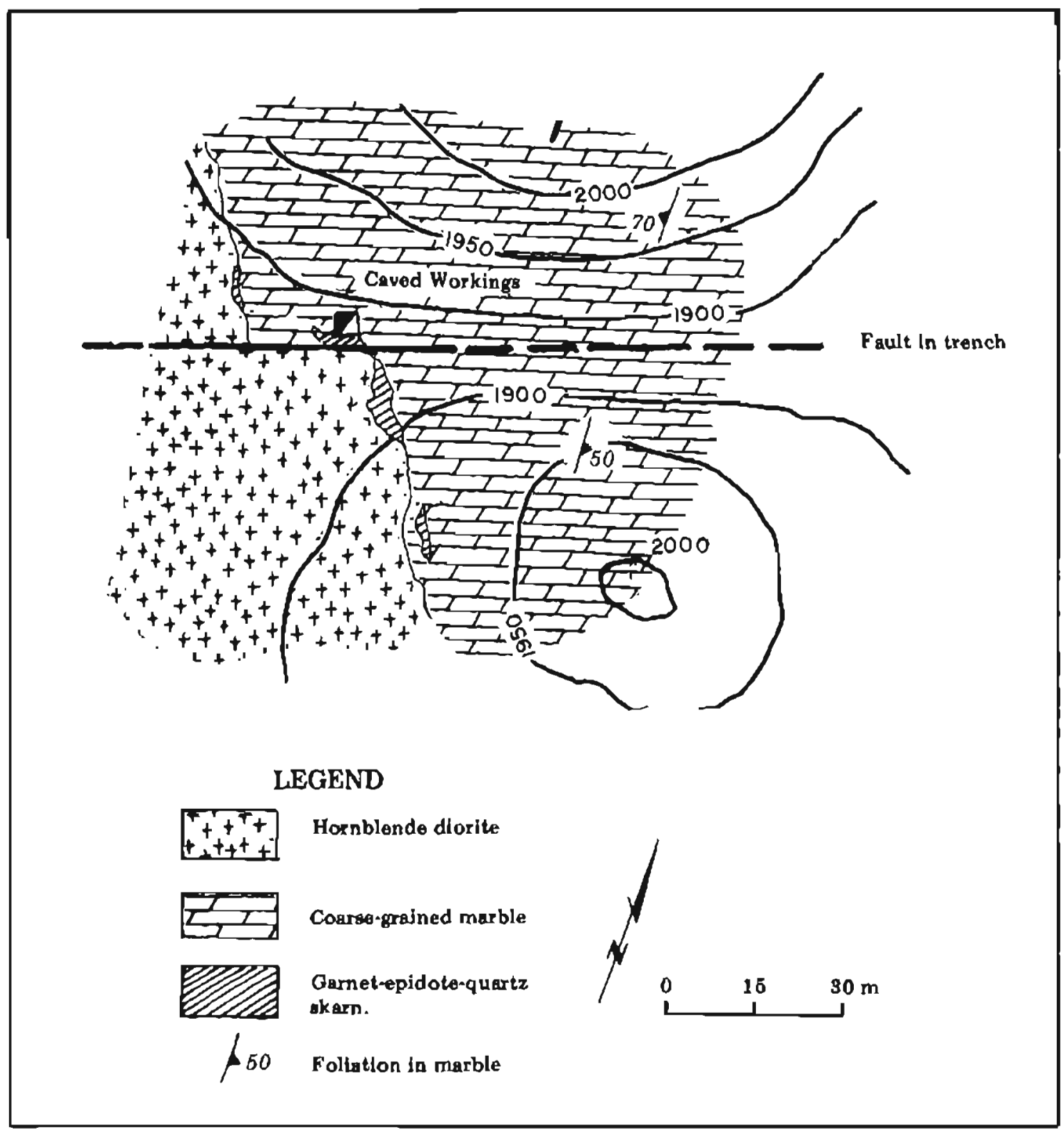

Figure 36. Geologic sketch map of Summit Lake prospect (locality 14, pl. 1).

the vein strikes east-west, dips steeply, and is located along a marble-hoinfels contact. A selected sample (No. 67. pl. 2) of quartz-sulfide mateyial yiejded $3.0 \mathrm{oz} / \mathrm{lon}$ silver, 0.91 percent copper, $140 \mathrm{ppm} \mathrm{lead,} \mathrm{and} 0.21$ percent zinc. This showing is probably the one described by Wright (1915, P. 64-65) as a plt $3 \mathrm{~m}$ deep and $100 \mathrm{~m}$ east of the main exposure of Gould Island, which contains a low-grade zone of galena, sphalerte, and chalcopyrite veinlets. According to Wright, the zone at the main exposure is $9 \mathrm{~m}$ wide, contains bow-grade ore, strikes east-west, and dips steeply north; it contains calcile, quartz, garnet, epidote, and wollastonite in marble and has been explored by a 21-m-iong adit, a 3-m-deep shaft, and an open cut. This mineralized zone likely represents a metasomatic skarn deposit.

\section{HETTA MOUNTAIN PROSPECTS}

Two copperabearing zones in marble cross the southwest end of the summil ridge of Hetta Mountain at the 2,800-ft elevation (localities 17a,b, pl. 1). These and other showings are mentioned briefly by Wright (1915, p. 65) and all adits and pits probably predale Wright's visit in 1908. There are two short adits near the top of the rldge. One is at about 2,700 it (Wright's " 2,480 -ft adit") in a shear zone $25 \mathrm{~m}$ thick in which the marble matrix is cut by veinlets and blebs of chalcopyrite and limonitized skarn veins with a diopside-gannet-quart? mineralogy. The trenched shear zone strikes east-west, and dips $75^{\circ}$ norlh, and is cut off $100 \mathrm{~m}$ lo the east by a north-trending fault. 
About $30 \mathrm{~m}$ north of the 2,700-fi adit, at the 2,675 ft elevation, is a 40 -m-long adit used to explore three short en echalon pods, 6 to $20 \mathrm{~m}$ apart, of massive pyrite-pyrrhotite-chalcopyrite mineralization. These strongly limonitized pods, which are up to $3-1 / 2 \mathrm{~m}$ thick, are replacements in maxble along a porphyritic dlorite dike. A polished section of sulfides from the deposit shows major pyryhotite and chalcopyrite with minor goethite, pyrite, and sphalerite. The chalcopyrite makes flamelike intrusions into the pyrxhotite along crystal boundaries and small cracks. The pyrrhotite is partly replaced by goethite, pyrite, and possibly marcasite. 'Breccia dikes' of fragmental chalcopyrite and pyrite-bearing material crosscut all sulfides and suggest movement during or after mineralization. A grab sample (No. 144, pl. 2) had 2.2 percent copper, 0.74 percent zinc, $22 \mathrm{ppm}$ lead, $12.8 \mathrm{oz} /$ ton silver, $0.10 \mathrm{oz} / \mathrm{ton}$ gold, $600 \mathrm{ppm}$ molybdenum, and 750 ppm cobalt. These two copper-zincbearing zones on either side of the porphyry dike do not extend beyond the fault to the east and underlie a 15-m-thick rusty-weathering layer of quartz-diopside hornfels that extends to the west.

The pyrite-chalcopyrite-garnet-epidote showings between Hetta Mountain and Wright Creek mentioned by Wright (1915, p. 65) were not visited. Their estimated locations are shown on plate 1 .

\section{CORBIN MINE}

Production began on the Corbin mine (locality 12 , pl. 1), located on the east side of Hetta Inlet, $2 \mathrm{~km}$ north of Copper Harbor, in 1906 (Wright, 1915) and continued intermittently for 7 years (Bufvers, 1967, p. 21). Workings included a $30 . \mathrm{m}$-long shaft, several $30 \mathrm{~m}$ drifts, and an adil about $70 \mathrm{~m}$ long on the level of the drifts (Ẽg. 37).

Apparently, the only ore mined was in a $25-\mathrm{cm}-10$ 1-m-thick steeply plunging lense of massive, banded, pyrite-chalcopyrite-sphalerite mineralization carrying about $\$ 3.00 /$ ton in 1908 gold and silver prices and several percent copper and zinc (the zinc was not recovered). The ore shoot parallels the foliation and compositional banding in the Wales Group schist bedrock and shows extensive shearing and faulting along the bedding planes. Exposures at the south end of the slope show a bedding-plane shear zone about $1.5 \mathrm{~m}$ wide with talcy fault planes and both parallel and cross. cutting quartz veins. Along the fault east of the mined. out ore body, the bedrock is bleached green schist with sparcely disseminated pyrite, minor chalcopyrite, and encrustations of malachite and azurite. A chip sample (No. 98, pl. 2) across $3 \mathrm{~m}$ of limonite and disseminated pyrite contained only 500 ppm copper, 200 ppm zinc,

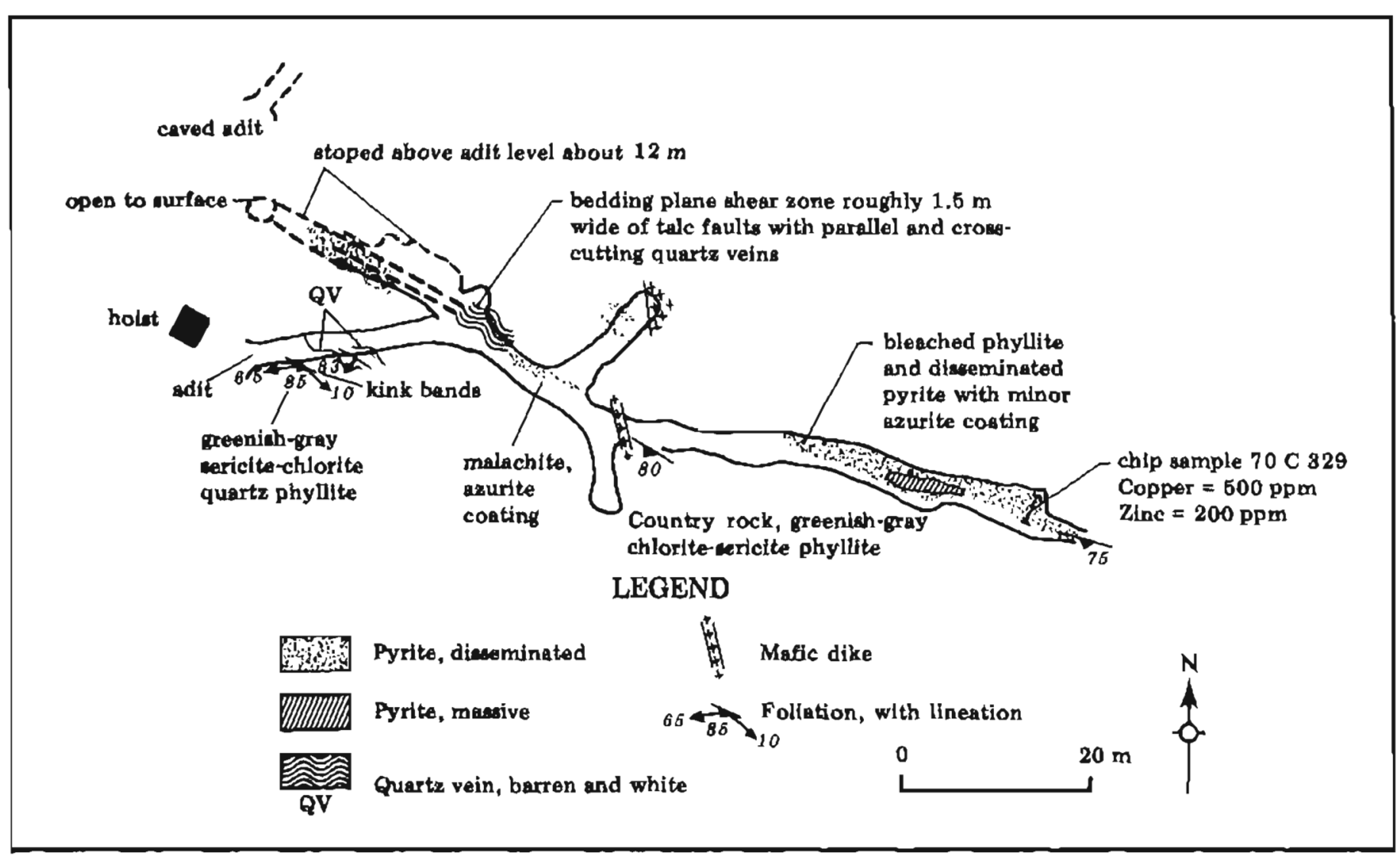

Figure 37. Geologic sketch map of the Corbin mine workings, east side of Hetta Inlet (locality 12, pl. 1). 
and background amounts of other metais. A grab sample of siliceous rock from the dump (No. 96, pl. 2) contained 5.6 percent copper, 0.1 percent zinc, 80 ppm lead, $15 \mathrm{ppm}$ silver, and $300 \mathrm{ppm}$ molybdenum.

Prospect trenches north of the mine have a $25 \cdot \mathrm{m} \cdot \mathrm{wide}$ expostre of kink-banded sericitized green schist with quartz veiniets and malachite stain. Several zones of pyritized rock and irregular quartz veins along the beach in the vicinity indicate a fairly extensive area of siliceous schists,

Although the geologic setting suggests a massive sulfide volcanogenic origin for the Corbin deposit, it could be a fault-controlled sulfide shool associated with the end of the last regional deformation.

\section{COPPER CITY MINE}

The Copper Cily mine (locality 20, pl. 1; Iigs. 38, 39 ) is situated just above the high-tide line on the east shore of Hetta Inlet, approximately $10 \mathrm{~km}$ south of Copper Harbor. It was prospected by E.E. Wynals in 1898 (Bufvers, 1967, p. 21-22). Production began 5 years later (Wright, 1915, p. 64) and continued fairly continuously on a small scale until 1910, whell the inine was hooded through a drill hole.

An inclined shafk was sunk to a depth of about $100 \mathrm{~m}$, drifis were run at various levels along the deposit and the mineralization was stoped to the surface. According to Wright, the deposit exposed in the shaft was massive-sulficle ore ranging from $20 \mathrm{~cm}$ to $1.2 \mathrm{~m}$ thick. The ore is cut by diabase dikes in which "subsequent mineralization has deposited small amounts of minerals in veinlets" (Wright, 1915). He continues (p. 64):

"Similar but smaller veins, trending parallel to the main veill, have been exposed by surface cuts and trenches.... The ore is composed essentially of chalcopyrile, pyrite, splialerile, and rarely hematite (specularite), associated with quartz, calcite, and epidote gangue minerals.... In addition to copper each ton of ore contains gold amounting to $\$ 3$ to $\$ 6$ and silver amounting to $\$ 1$ to $\$ 4$, as well as six to nise percent zinc."

According to Wright and Wright (1906), a total of 1,600 tons of ore worth $\$ 60,000$ had been mined through 1905.

The site is now overgrown witl limber but the main stope is visible just above high tide for more than $100 \mathrm{~m}$ along the beach. This deposit is closely associated with metakeratophyre, metaspilite, and a consplcious grayish-red quartz sericite sclist of the Wales Group (fig. 38). The mineralized zone is parallel to com. positional banding and roliation in the bedrock. The deposit is faulted and some wall-rock alleration is evident. Talcose micaceous material is found in the hanging wall of the deposit and there are many irregular crosscutting quartz veins 2 to $25 \mathrm{~cm}$ thick in the grayishred quatiz sericite schist. These veins roughly parallel gently plunging later kink bands that deform earlier fine crenulations that plunge steeply to the northwest. The quartz veins were probably deposited during kink. band deformation in the Wales Group. The movement indicated by these kink bands is compatible with com. pression from the west. A distinct airphoto lineament crosses the creek near the Copper City mine, aboul $0.5 \mathrm{~km}$ from the workings.

A chip saniple across $25 \mathrm{~cm}$ of banded mineralizalion yielded 8.50 percent copper, 7.30 percent zinc, $2.5 \mathrm{oz} /$ ton silver, $0.05 \mathrm{oz} / \mathrm{ton}$ gold, $570 \mathrm{ppm}$ lead, and $7,000 \mathrm{ppm}$ barium (No. 183, pl. 2). A polished section of secondary(?) vein mineralization revealed major chal. copyrite and minor sphalerite in a gangue of quartz. The chalcopyrite is partly replaced by digenite.

The deposit appears to be, in part, a quartz vein 5ystem associated witl a fracture zone; lowever, its bedrock associations, metallic content, banded sulfides that have been deformed, and parallekism to the wall rock suggest a massive-sulfide volcanogenic deposit that was modified during regional dymannothermal metamorphism of the Wales Group.

\section{LIME POINT BARITE PROSPECT}

The barite deposit at Lime Point (locality 21, pl. 1) was discovered in 1912 and in 1915 Charles Sulzer made a test shipment of the ore that returned "satisfactory" results. The $12-\mathrm{m}$-long adit that exists today probably dates from this period. Twenhofel and others (1949, p. 17.19) estimaled the tonnage of ore above high tide to be 5,000 cons of material containing 91 percent barite.

The deposit occurs as interlayered lenses of barite and dolomite in Wales Group marble (fig. 40). Most lenses are less than $2 \mathrm{~m}$ thick and are terminated within

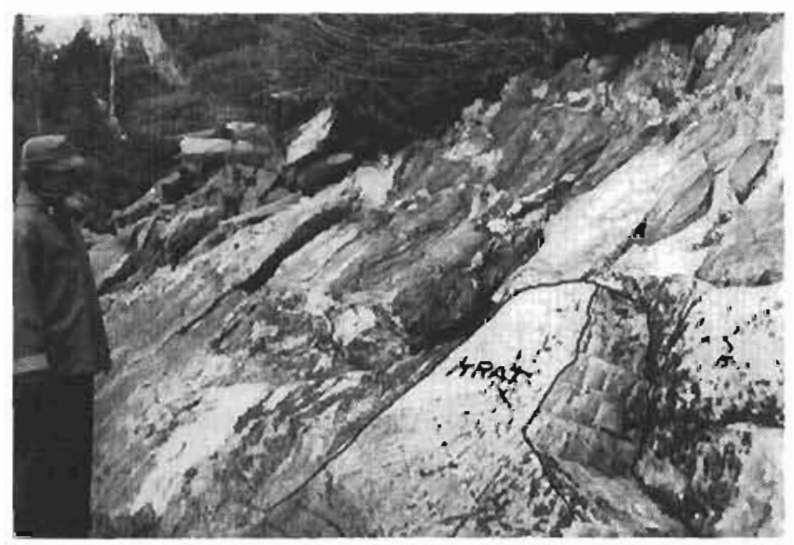

Figure 38. Metakeratophyre bed (Kral) and underlying quartz sericite schist in hanging wall of Copper City Mine. 


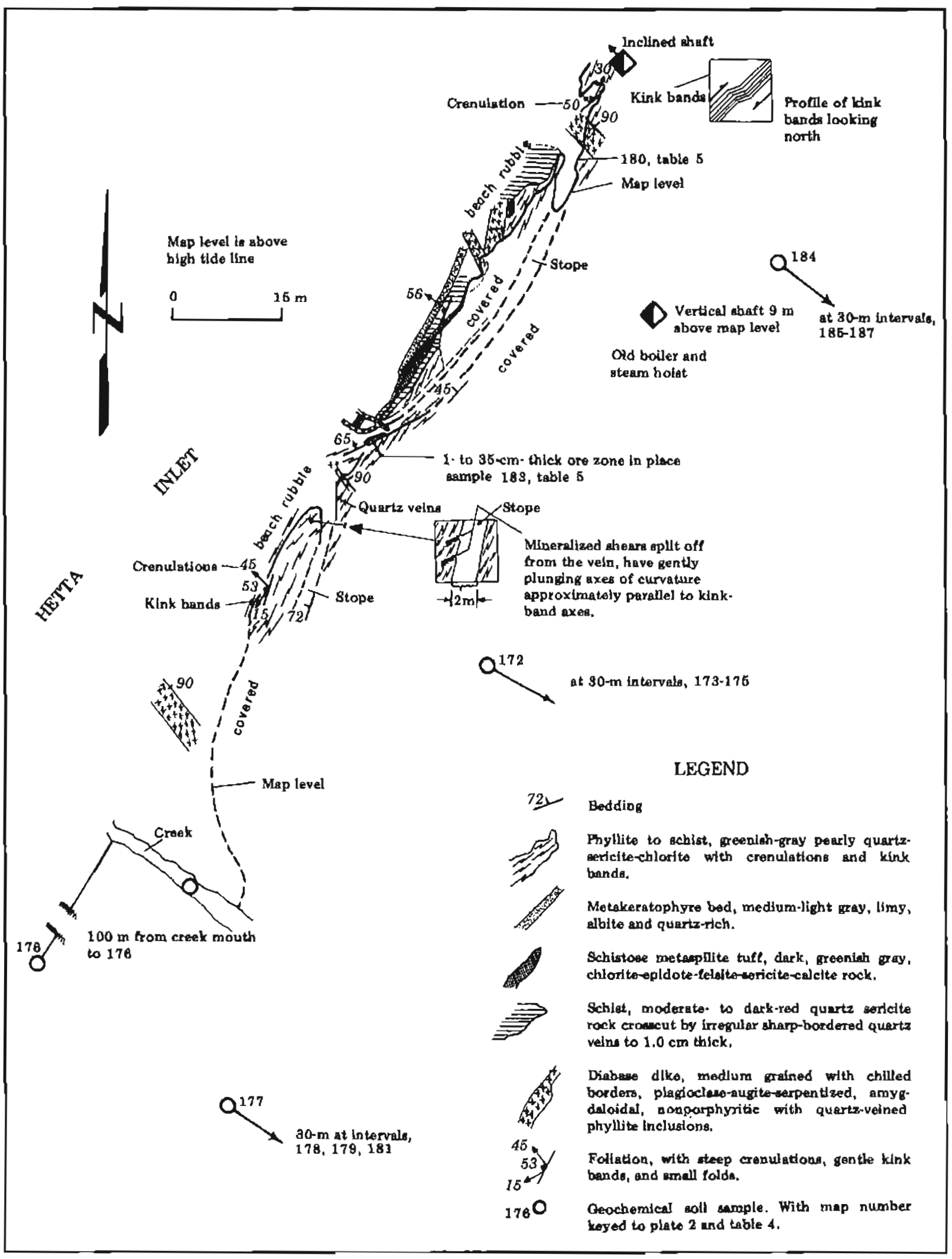

Figure 39. Geologic map of Copper City mine (locality 20, pl. 1). 
$12 \mathrm{~m}$ by faulting. Barite found in the axes of folds is deformed. As at Copper City and Corbin, the baritedeposit probably has a premetamorphic origin. Sub. sequent faulting displaced the Lime Point deposit in a complicated fashion, and altered andesite dikes were intruded along these faults.

\section{NUTKWA LAGOON PROSPECT}

This prospect is located at an elevation of 110 feet on the northwest side of Nutkwa Lagoon about $1,200 \mathrm{~m}$ from its head (locality 23, pl. 1). Nutkwa Lagoon has a narrow entrance that can only be entered by shallow draft boats at slack water near high tide.

The prospect has a $120-\mathrm{m}$-long adit with a 15 -m-deep winze $60 \mathrm{~m}$ from the portal (Chapin, 1916, p. 90-91). According to Roetrm (1939), the adit follows a discontinuous quartz vein(?) up to $2 \mathrm{~m}$ thick that is along a mineralized shear zone striking $\mathrm{N}$. $20 \cdot 30^{\circ} \mathrm{W}$. and dipping $80^{\circ} \mathrm{W}$. The wall rock is Wales Group (Wg) green schist. Sultide minerals present are chalcopyrite, galena, and pyrite, but they generally make up only a small percentage of their mineralized zone (1'wentiofel and others, 1949). The deposit reportedly produced $50 \mathrm{oz}$ of gold, 3 oz of silver, and $36 \mathrm{lb}$ of lead in 1938 (Wolff and Heiner, 1971). Twenty-two channel samples across the mineralized zone (Roehm, 1939, p. 3.5) average 0.06 oz/ton gold and $0.13 \mathrm{oz} / \mathrm{ton}$ silver. The highest value was $0.66 \mathrm{oz} /$ ton gold, $70 \mathrm{~m}$ from the portal.

\section{KEETE INLET PROSPECT}

According to Chapin (1916, p. 90):

"A prospect near the head of Keete Inlet has been developed recently on a copper-bearing lode strike N. $20^{\circ}$ W. and dipping $60^{\circ}$ NE. The lode is being opened by an incline, which below the 10-foot level was covered with water and in. accessible at the time of visit. The ore is a shear-

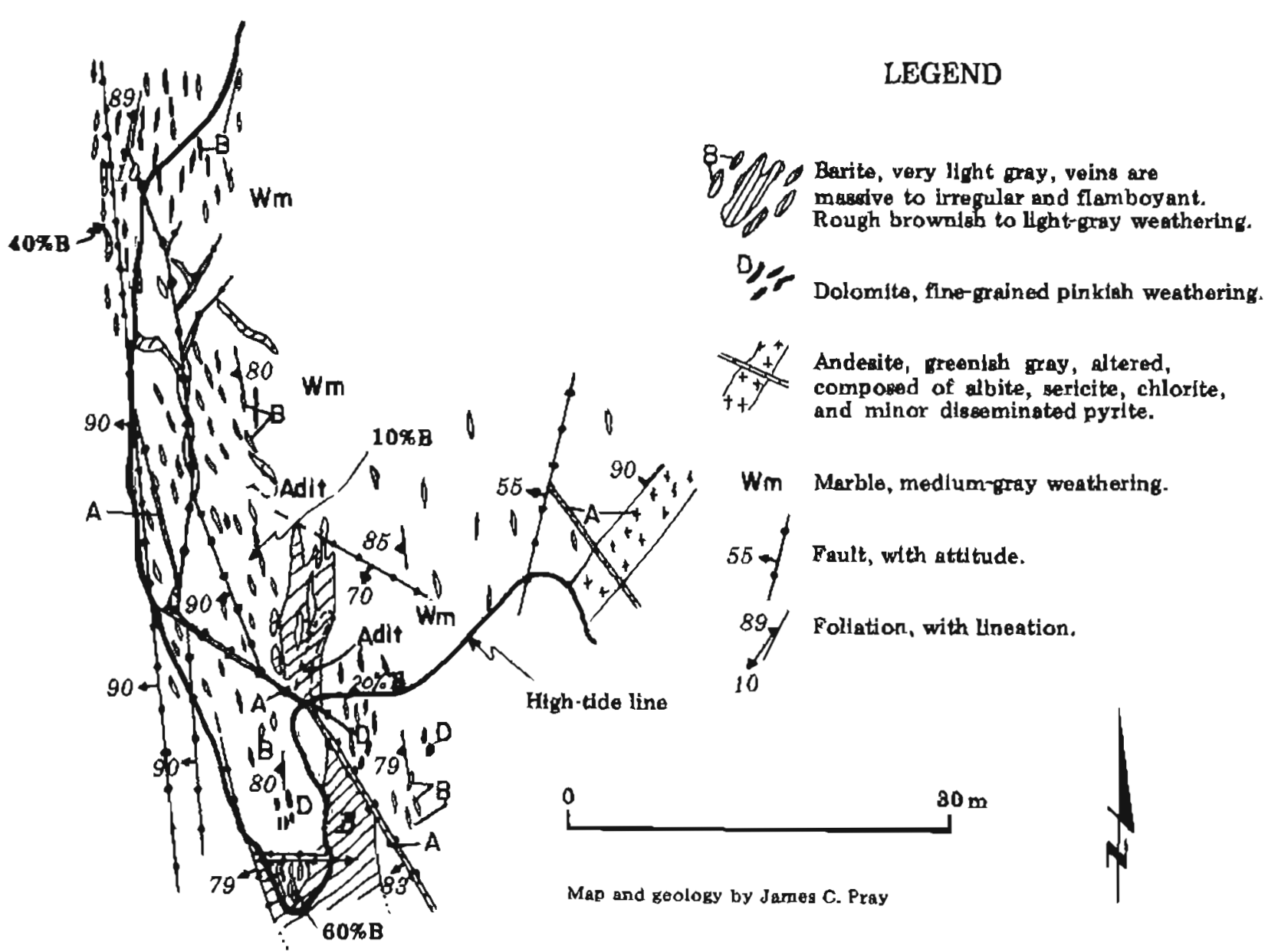

Eigure 40. Geologic map of Lime Point barite deposit (locality 21, pl. 1). 
zone deposit containing disseminated particles and lenses of chalcopyrite and pyrite in siliceous beds occurring in greenstone schist. On the dump were samples of quartz veins carrying bornite and chalcopyrite, but similar rock was not seen in place. The property is a short distance from tidewater and is equipped with a blacksmith shop and cabins bullt on a small cove."

This prospect was sought but not found during mapping. Its location on plate 1 (location 22) is uncertain.

\section{FRIENDSHIP SILICIFIED ZONE}

On both sides of South Arm, near the north end (pl. 1), a large area of Wales Group silicified schist is belleved to be formed either from metamorphic 'sweating' of quartz out of the country rock or from thermal heating by a buried intrusive. The silicipied schist forms steep, grayish-orange weathered slopes and cliffs on the west shore of South Arm, where silicification and pyritization is strongest (pl. 1). Anomalous amounts of lead and zinc in creek sediments, soils, and bedrock are present. Two mineral deposits are known and both were under development in 1901 when Brooks visited the area: the Friendship and Polymetal lodes ("Ketchikan Copper Company," Brooks, 1902, p. 87-88). The sillicfied zone extends up to and possibly beyond the ridge west of the inlet and east an unknown distance across the inlet.

The Friendship iode (locality $25, \mathrm{pl} .1$ ) is a chalcopyrite-bornite-quartz vein deposit that extends $200 \mathrm{~m}$ along the Friendship fault, which is the contact between Wales Group marbie and green schist (Brooks, 1902, p. B7). Several old pits and copper showings on this zone were visible in 1972. A polished section of the vein shows small masses of chalcopyrite, bornite, and pyrite In a gangue of quartz and calcite. Some of the pyrite has a botryoidal texture. Both chalcopyrite and pyrite are rimmed locally with goethite. Analysis of a vein sample shows 0.51 percent copper, $900 \mathrm{ppm}$ yttrium, and 10 ppm bismuth.

The Polymetal lode has an adit reported by Brooks $(1902$, p. 88$)$ to be 300 feet $(95 \mathrm{~m})$ long at an elevation of 900 feet. Fowler (1949) reports this adit to be about 280 feet $(89 \mathrm{~m})$ long at an elevation of 500 leet. According to Brooks (1902, p. 88):

"The ore body, as far as determined, is a mineralized zone, which occurs in a quart2sericite-schist. This schist is made up essentially of bluish quartz and sericite, and it is of ten banded. Chlorite is a very common accessory mineral. While it has many of the characteristics of an altered sediment, yet it strongly resembles the schists found in association with the ores at Niblack Anchorage, which are believed to be altered rhyolites."
During the mapping, several days were spent tra. versing the steep slopes, but the workings were not found. Fowler reported the mineralized zone to be $6.5 \mathrm{~m}$ wide and to contain 11.4 percent zjnc, 2.8 percent lead, and a trace of silver. Low-grade disseminated sphalerite can be found in several schist outcrops in the hill slopes below the 500-ft elevation. The earlier descriptions suggest that this may be a stratiform mineral deposit as present at Niblack (Peek, 1975).

Geochemical stream-sediment and soll samples taken just above the beach below the Polymetal lode indicate that a zone highly mineralized in lead, zinc, and silver, with lesser amounts of copper, zirconium, and yttrium extends for about $600 \mathrm{~m}$ along the inlet and about 500 $m$ up the mountain slope to the west.

The presence of rare-earth elements in stream sediments and the Friendship vein may indlcate that a mineralized intrusion similar to Bokan Mountain (MacKevett, 1957) underlies the silicified schist (Ws).

\section{MOONSHINE GROUP}

A small group of lead-zinc-silver deposits is located on a prominent north-south ridge west of the South Arm of Cholmondeley Sound. The Moonshine mine (locality $26 a, b ;$ pl. 1) was staked around 1900. Development work was started in 1906, and a 3-m-thick vein that carried 1,500 oz/ton of silver was reportedly struck in 1909. Several tunnels, a shaft and a long raise to the top of the ore body were driven (Bufvers, 1967, p. 23) and an aerlal tram was installed before the final mine ciosure (1922). An adit at the 2,230-ft elevation was driven to undercut the ore body at depth and an attempt was made to reach the shaft at the top of the ridge with a long raise. Unfortunately, a cavity in the marble was intersected and the ground caved, creating the glory hole at the 2,620-ft elevation. The partly caved adit at the 2,230-ft elevation shown on figures $\$ 1$ and 42 is near the top of the ruined aerial tram and the remains of the old camp. No records of the production are avaiIable but it is not believed to have been great.

According to Wright (1909, p. 182-188):

"The Moonshine vein, as it is called, occupies a well-defined fissure, cutting obliquely across limestone and schist country rock and traversing the top of the mountain ridge. Where it crosscuts the limestone it is apparently a replacement deposit, varying from a few inches to several feet in width and carrying considerable galena associated with quartz, slderite, and calcite, though where the schist forms the enclosing walls the vein is smaller and is in many places represented by a narrow gouge seam. The country rock strikes nearly east and west and dips north at steep angles, whereas the vein strikes $N .65^{\circ} \mathrm{W}$. and has a vertical dip. In this vein deposit the mineral occurs irregularly, the ore being found in 
smail scattered masses or bunches. Besides the galena a small amount of sphalerite and chalcopy. rite is present in the ore. Very little surface alteration or secondary enrichment was observed, and where present it extends but a few feet in depth. Diabase dikes from 1 foot to 6 feet in width crosscut both the country rock and the ore body."

The Moonshine deposits líe along a fault near a Wales Group marble-green schist contact adjacent to a large area of Wales Group silicined green schist. The mineral. ization was accompanied by dolomitization and quartz veining in the wall rock (fig. 42). Mineralization from the dump is composed of galena and sphalerite plus minor chalcopyrite and accessory pyrite and siderite. A polished section of the massive galena vein exposed in the glory hole shows Ealena, minor blebs of polybasite, and traces of covellite. Several grab samples (Nos. 419, 420, 421; pl. 2) varied in metal content from 20 to 83 percent lead and 12 to 30 oz/ton silver.

Several other lead-zine prospects in Wales Group marble (Wm) are present on the ridge southeast of the Moonshine Mine (fig. 41). Two of them are along dolomitized fault zones in the marbie near marblepresent at prospect A (fig. 41, and locality 26b, pl. 1). Mineralization consists of small high-grade 'kidneys' less than a meter wide of gatena, sphalerite, and siderite in a dolomitized vein breccia.

At prospect B (fig. 41 and locality 26c, pl. 1) a short adit into the marble wallrock near a marble-schist contact zone contains small isolated masses $(<100 \mathrm{~cm}$ in diameter) of galena and sphalerite.

The two marble layers that contain the base-metal veins are on the limbs of a southeast.trending anticline. This anticline is apparently near the axis of a major fold structure mapped to the east as the Dolomi-Sulzer anticline (pl. 1, section D.D'). Longitudinal fracturing associated with the lolding may have controlled the distribution of the vein channels; subsequently, the suffides replaced $\mathrm{CaCO}_{3}$ along the limestone schist contacts and within marble beds themselves.

\section{DISCUSSION}

The Precambrian and Paieozoic rock units described in this report are considered to be part of a Jargey group of problematically old border terranes that have been

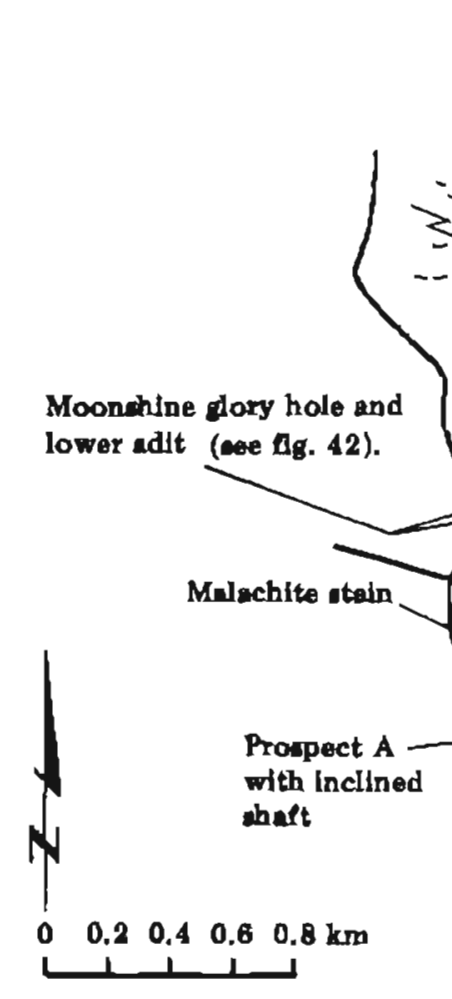

$\begin{array}{llllll}0 & 0.2 & 0.4 & 0.6 & 0.8 \mathrm{~km}\end{array}$
9160

$\chi_{0_{0} w_{8}}$

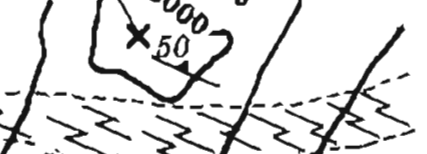

$\mathbf{W}$

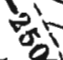

on 3015

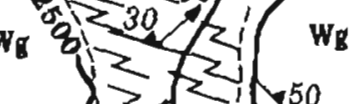

W
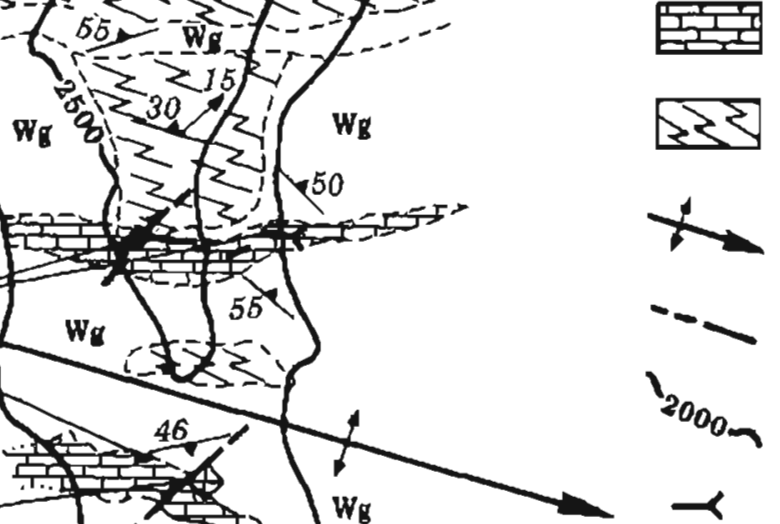
plunge.

\section{plunge.}

Wales Group green schlst, with barren quartz velns and kink bands.

Marble, medium cryetalline and locally banded.

Silfcified achist, locally compawed of up to $60 \%$ quartz veíns.

Anticline with direction of

Fault, dashed where in ferred.

Elevation contour (tn foot).

Adit

Mine thaft

Follation with kink banda 


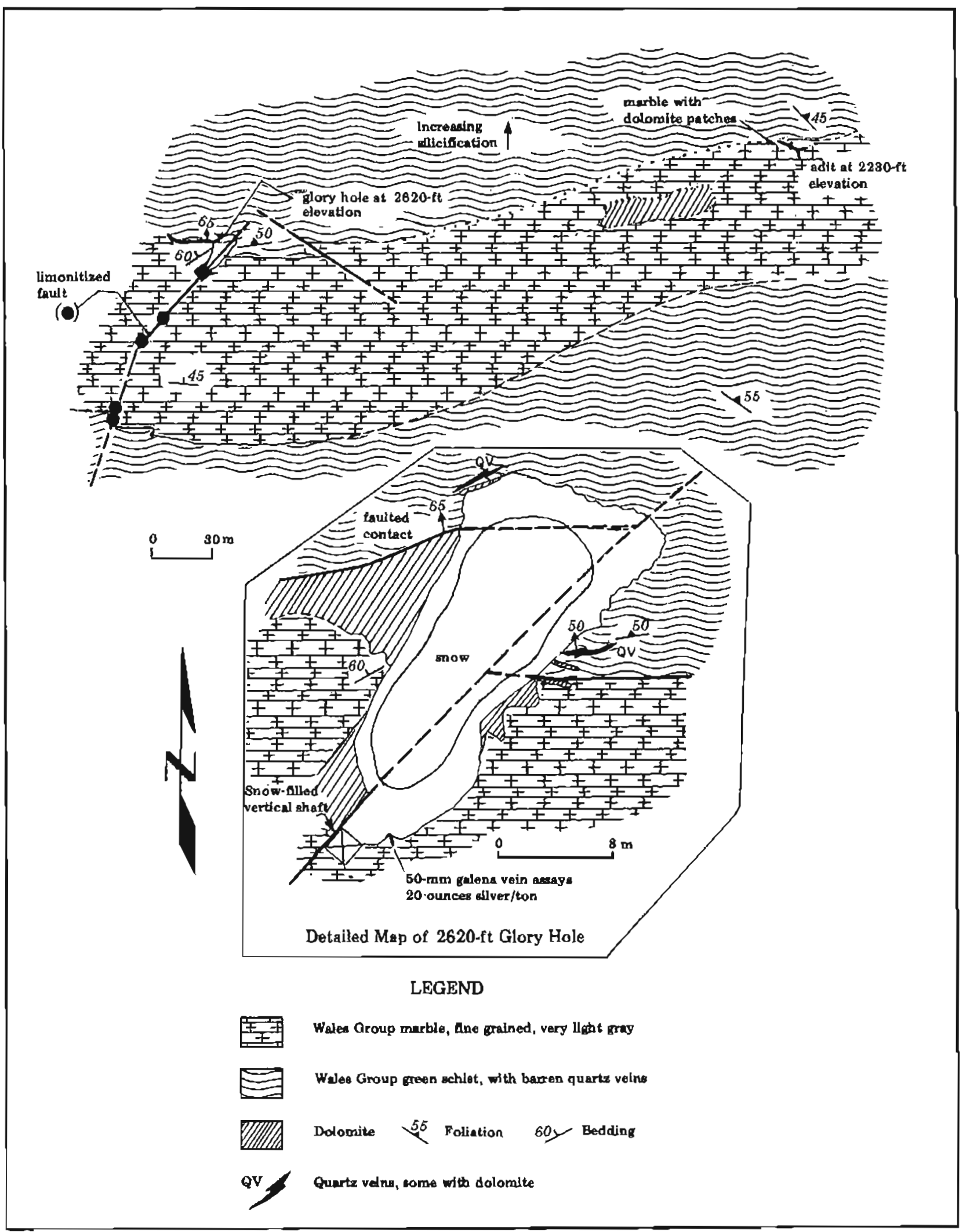

Figure 42. Geologic map of the Moonshine mine (locality 26, pl, 1). 
sutured along the western edge of North America since Mesozoic time. Distinct Paleozoic and Precambrian sedimentary-plutonic-voicanic 'packages' extend discontinuously from southern Alaska to southern California (and possibly beyond) and are often seaward of younger orogenic sequences. This geological discrepancy, among others, has generated a number of theories on the tectonic history of these terranes that incorporate plate movement (Churkin and Eberlein, 1977).

Berg and others (1972) include the rocks on Prince of Waies Island as part of the 'Alexander terrane,' a group of fossiliferous volcanic-sedimentary sequences of early and mid-Paleozoic age that extends from south-central Alaska to the Queen Charlotte Isiands in British Columbia. Attempting to match the rocks of the Alexander terrane with equivalents southward has proven extremely difficult and Churkin and Eberlein (1977), on the basis of studies of stratigraphic sections along the North American margin, propose that multiple plates or 'microplates' moved outboard and inboard from North America during Precambrian and Paleozoic orogenic cycles and were later rifted northward by large-scale strike-slip movement.

The detalled descriptions of the geology of southern Prince of Waies Island reported here and radiometric dating discussed by Turner and others (1977) may further define the problems of the rock-section correlations along the boundary of western North America, Such Peatures as 1) the bimodal sodic-rich nature of Wales Group volcanism, 2) the base-metal content of massivesulfide deposits hosted in the Wales Group, 3) the dynamothermal metamorphic signature of the Wales Group, 4) the detalled stratigraphic sections of Ordovician and Devonian sedimentary units, 5) the aromalous rare-earth elemental backgrounds of Devonian volcanics of the Craig A-2 quadrangle area, 6) the distinctive conjugate swarm of mafic dikes intruding the Paleozoic-Precambrian section, and 7) the chemistry and physical chazacter of Paleozoic and Mesozoic granitic plutons of the area may be compared with equivalent terranes to the south.

In addition, the data derived from the Mineral Deposits section of this report may provide a framework to estimate the mineral resource potential of southern Prince of Wales Island.

\section{ACKNOWLEDGMENTS}

The authors wish to thank John T. Dillon, Gilbert R. Eakins, Michael Churkin, Jr., and G. Donald Eberlein for critically reviewing the manuscript. John $R$. Carden helped calculate the CIPW norms for the whole-rock chemical analyses. We thank Eskil Anderson for providing unpublished reports of the Jumbo Basin mineral deposits. James C. Pray provided able assistance and mapping expertise during the 1970-72 fjeld seasons. Thanks are due to pilots of Ketchikan Air Service for efficient air, radjo, and logistical support. Frank L. Larson, Roberta A. Mann, and L.C. (Ann) Schell edited, typed, and drafted the narrative and illustrative parts of the report; their help is greatly appreciated.

\section{REFERENCES CITED}

Berg, H.C., Jones, D.L., and Richter, D.H., 1972 , Gravina-Nutzotin belt-Tectonic significance of an upper Mesozoic sedimentary and volcanic sequence in southern and southeastern Alaska, in Geological Survey Research 1872: U.S. Geol. Surv. Prof, Paper 800-D, p. D1-D24.

Brooks, A.H., 1902, Preliminary report on the Ketchikan mining district, Alaska: U.S. Geol. Survey Prof. Paper 1, 120 o.

Buddington, A.F., and Chapin, Theodore, 1929, Geology and mineral deposits of southeastern Alaska: U.S. Geol. Survey Bull, 800, 398 p.

Bufvers, John, 1967, Histary of mines and prospects, Ketchikan district, prior to 1952: Alaska Div. Mines and Minerals, $32 \mathrm{p}$.

Carmichel, I.S.E., Turnor, F.J., and Verhoogen, S., 1974, Igneous petrology: New York, McGraw-Hill, p. 427-603.

Carlysle, D., 1963, Pillow breccias and theil aquagene tulf: Jour. Geology, v. 71, p. 48-71.

Chapin. Theodore, 1916, Mining developments in southeastern Alaska: U.S. Geol. Survey Bull. 642-B, p. 9091.

1918, Mining developments in the Ketchikan and Wrangell mining districts, 1916: U.S. Geol. Survey Bull, 662, p. 63-75.

Churkin, Michael, Jr., Jaeger, H., and Eberlein, G.D., 1970, Lower Devonian graptolites from southeastern Alaska: Lethaia, v. 3, p. 183-202.

Churkin, Michael, Jr, and Eberlein, G.D., 1977, Ancient borderland terranes of the North American Cordillera; correlation and microplate tectonics: Geol. Soc. America Bull, v. 88, no. 6, p. 769.786.

Condon, W.H., 1961, Geology of the Craig quadrangle: U.S. Geol. Survey Bull. 1108-B, 41 p.

Dickenson, W.R., 1962, Metasomatic quartz keratophyre in central Oregon: Am. Jaur. Sci, v. 260, p. 249. 266.

Donnelly, T.W., 1963 , Genesis of albite in early orogenic volcanic rocks: Am. Jour. Sci, v. 261, p. 957-972.

Eberlein, G.D., and Churkin, Michael, Jr., 1970, Paleozoic stratigraphy in the northwest coastal area of Prince of Wales Island, southeastern Alaska: U.S. Geol. Survey Bull. 1284, 67 p.

Forgeron, F.D., and LeRoy, L.W., 1971, Geology and geochemistry of the McLean Arm property, Prince of Wales Island: U.S. Borax unpub. rept., $39 \cdot \mathrm{p}$.

Fowler, H.M., 1949, Report on the Polymetal lode, Prince of Wales Island, Alaska: Alaska Terr. Dept. of Mines (unpub.), 2 p.

Hawley, C.C., 1975, Stratabound volcanogenic deposits in Alaska, in Recent and ancient sedimentary environments: Alaska Geol. Soc. 1975 Symposium, p. 8596.

Herreid, Gordon, 1964, Geology of the Niblack Anchor- 
ags area, southeastern Alaska: Alaska Div. Mines \& Minerals Geol. Rept. 5, 10 p.

1967, Geology and mineral deposits of the Dolomi area, Prince of Wales Island, Alaska: Alaska Div. Mines \& Minerals Geol. Rept. 27, 25 p.

1971. Analyses of rock and stream sediment samples, Hetta Inlet area, Prince of Wales Ishand, Craig quadrangle, Alaska: AJaska Div, Geol. Survey Geochem. Rept. 24, 4 p.

Herreid, Gordon, and Trible, T.C., 1973, Analyses of stream-sediment samples, Craig A-2 quadrangle and vicinity, Prince of Wales Island, southeaslern Alaska: Alaska Div. Geol. and Geophys. Surveys Geochem. Rept. 27, 4 p.

Hogg, N., 1965, Eskil Anderson properties, Jumbo Basin, Prince of Wales Island, Alaska: Hanna Mining Co. (unpub.), $79 \mathrm{p}$.

Kennedy, G.C., 1953, Geology and mineral deposits of the Jumbo Basin, southeastern Alaska: U.S. Geol. Survey Prof. Paper 251, $42 \mathrm{p}$.

Kinkel, A.R., Hall, W.E., and Albers, J.P., 1956, Geology and base-metal deposits of the west-Shasta copper. zinc district, Shasta County, California: U.S. Geol. Survey Prof. Paper 285, 89 p.

Lanphere, M.A., MacKevett, E.M., Jr., and Stern, T.W. 1964, Potassium-argon and lead-alpha ages of plutonic rocks, Bokan Mountain area, Alaska: Science, v. 145, no. 3633, p. 705.707 .

Leavens, P.B., 1967, Mineralogy of the skarns in the Copper Mountain mining district, Alaska: Smithsonian Inst. pub. (grant 637), p. 287-291.

Lepeltier, Claude, 1969, A simplifjed statistical treatment of geochemical data by graphical representa. tion: Econ. Geol., v. 64, p. 538-550.

Mackevett, E.M., 1957, Soda-rich granite, Bokan Mountain, southeastern AJaska: Geol. Soc. America Bull., v. 12, p. 258

1957, Sodium-rich granite from the southern part of Prince of Wales Lsland, Alaska (abs.): Geol. Soc. America Abs. with Programs, v. 68, no. 12 , part 2, p. 1834-1835.

Nockolds, S.R., 1954, Average chemical compositions of some igncous rocks: Geol. Soc. America Bull., v. 65, p. 1007-1032.

Peek, B.C., 1975, Geology and mineral deposits of the Niblack Anchorage area, Prince of Wales Island, Alaska: Fairbanks, Univ. Alaska M.S. thesis, 50 p.

Pewe, T.L., 1975, Quaternary geology of Alaska: U.S.
Geol. Survey Prof. Paper 835, 145 p.

Robinson, G.D., and Twerhofel, W.S, 1959, Some leadzinc and zinc-copper deposits of the Ketchikan and Wales districts, Alaska: U.S. Geol. Survey Bull. 998C, p. 59.84

Roehm, J.C., 1939, Preliminary report of Jack Wilcox gold prospecl, Nutkwa property, Nutkwa Bay, Prince of Wales Island: Alaska Terr. Dept. Mines (unpub.), $6 \mathrm{p}$.

Rossman, D.L., Henderson, J.R., Jr., and Walton, M.S., Jr., 1856, Reconnaissance tolal intensity aeromagnetic map of the southern part of Prince of Wales Island, Alaska: U.S. Geol. Survey Geophys. Inv. Map GP-1 35.

Slemmons, D.B., 1962, Determination of volcanic and plutonic plagioclases using a three- or four-axis universal stage: Geol. Soc. America Spec. Paper 69, $37 \mathrm{p}$.

Turner, D.L., Herreid, Gordon, and Bundtzen, T.K., 1977, Geochronology of southern Prince of Wales Island. Alaska, in Short notes on Alaskan geology, Alaska Div. Geol, \& Geophys. Surveys Geol. Rept. 55, p. 11.16 .

Twenhofel, W.S., Reed, J.C., Gates, G.O., 1949, Mineral investigations in southeastern Alaska: U.S. Geol. Survey Bull. $963-\mathrm{A}, 44 \mathrm{p}$.

Wahrhaftig, Clyde, 1965, Physiographic divisions of Alaska: U.S. Geol. Survey Prof. Paper 482, 52 p.

Winkler, H.G., 1967, Petrogenesis of metamorphic rocks: Springer-Verlag, New York, $237 \mathrm{p}$.

Wolf, E.N., and Heiner, L.E., 1971, Mineral resources of southeastern Alaska: Fairbanks, Univ. Alaska Mineral Industry Research Lab. Rept. 28, p. 75-106.

Wright, C.W., 1907, Lode mining of southeastern Alaska: U.S. Geol. Survey Bull. 314, p. 47.72.

1908, Lode mining in southeastern Alaska, 1907: U.S. Geol. Survey Bull. 345, p. 78-97. 1909, Mining in southeastern Alaska in 1908: U.S. Geol. Survey Bull. 979 , p. 67-86.

1915, Geology and ore deposits of Copper Mountain and Kassan Peninsula, Alaska: U.S. Geol. Survey Prof. Paper 87, $110 \mathrm{p}$.

Wright, F.E., and Wright, C.W., 1906, Lode mining in southeastern Alaska: U.S. Geol. Survey Bull. 284, p. 30.

1908, The Ketchikan and Wrangell mining districts, Alaska: U.S. Geol. Survey Bull. 347, 210 p. 